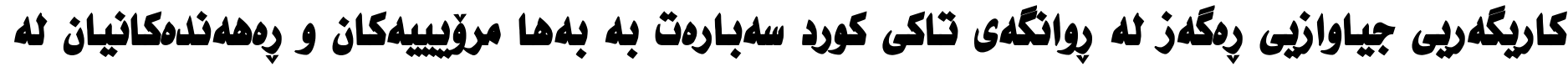

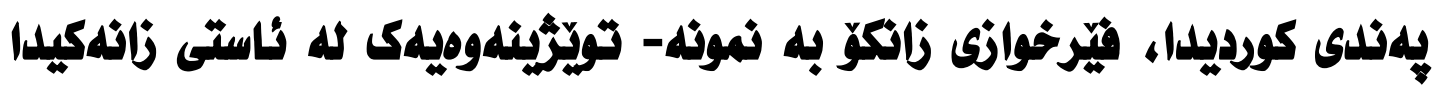

\author{
هيّمن علبلدولجهميل شهمس

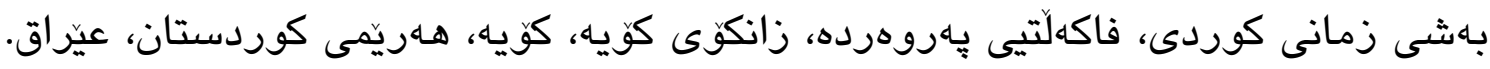 \\ hemin.shams@koyauniversity.org يُيمـهيل
}

\section{خاليد تيسماعيل مستهفا}

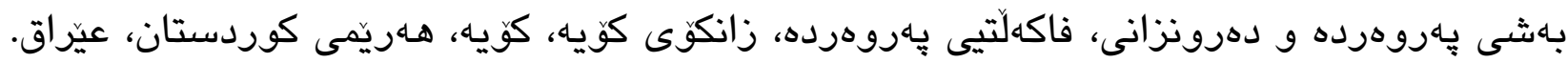
kيمـهلْ: khalid.ismail@kyauniversity.org

هوخته:

ناونيشانى تويّزينهوهكه (كاريكَهيى جياوازيى رهكهز له روانكهى تاكى كورد سهبارهت به بهها مروّيييهكان و

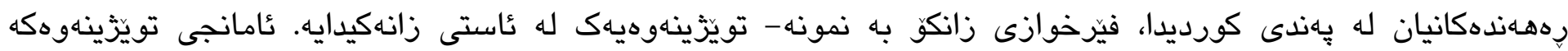

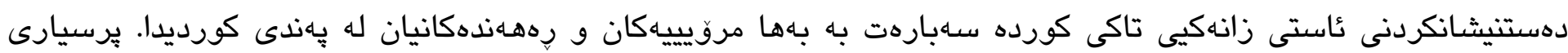

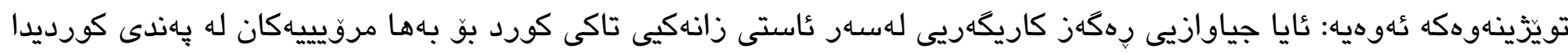

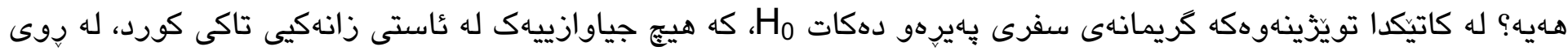

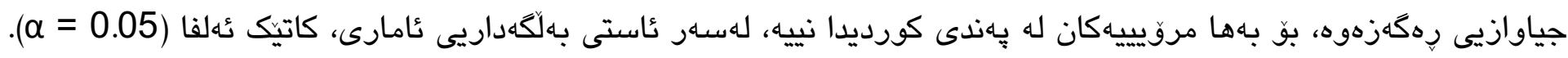

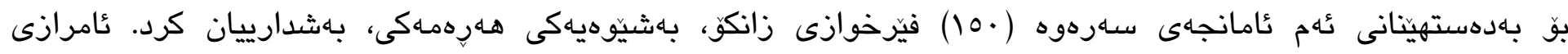

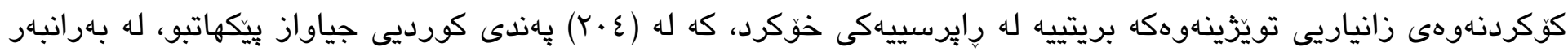

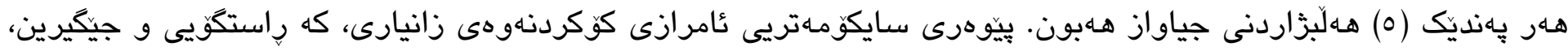

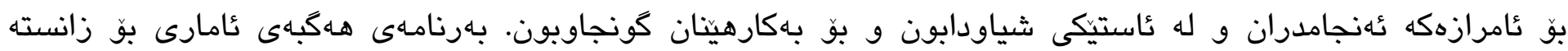

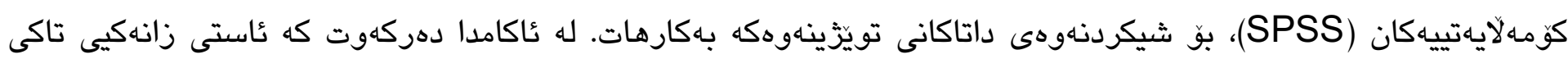

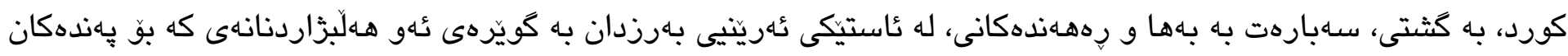

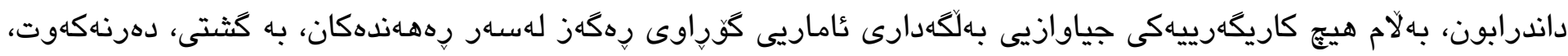

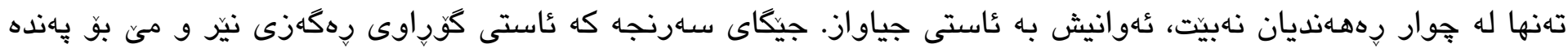

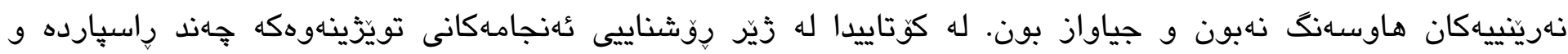

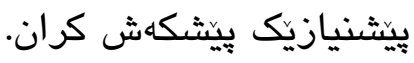

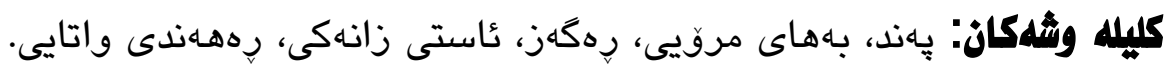




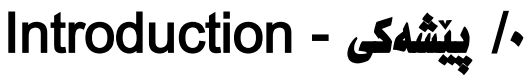

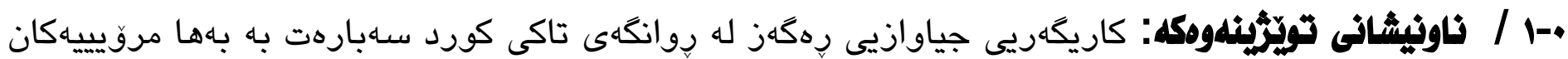

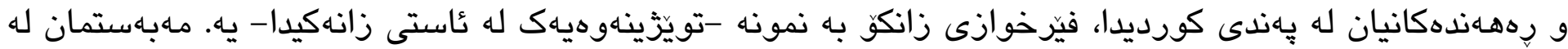

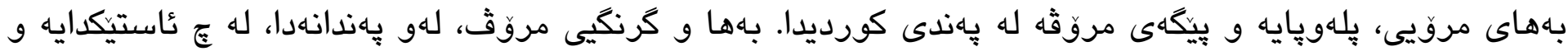

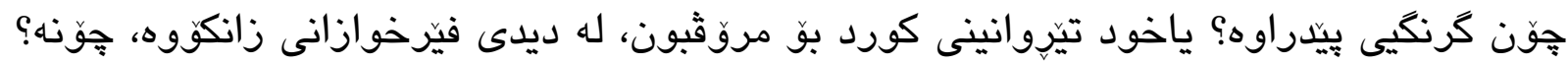

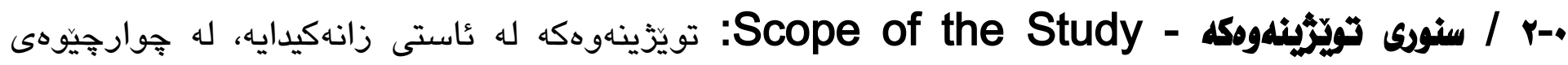

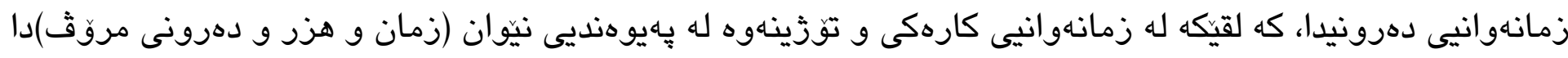

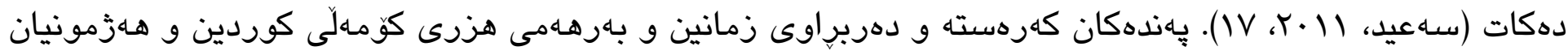

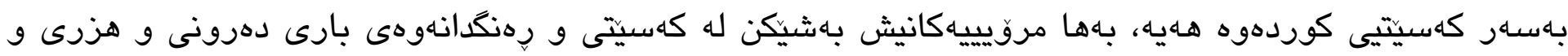
زانهيى تاكى كوردن.

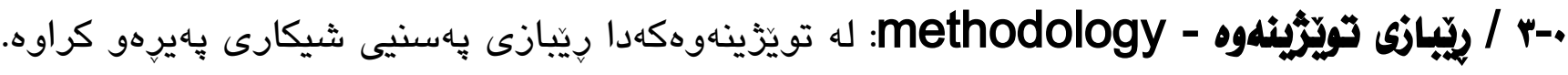

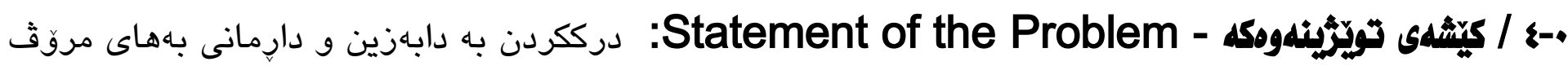

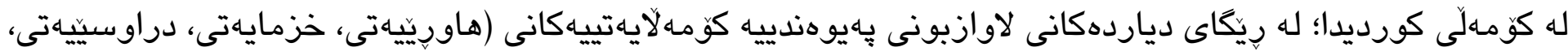

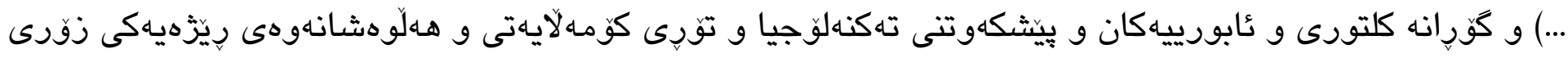

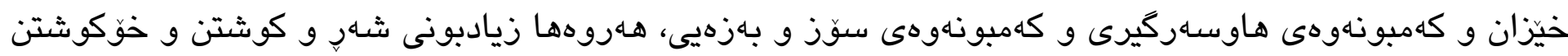

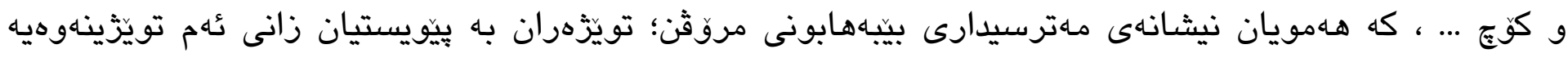

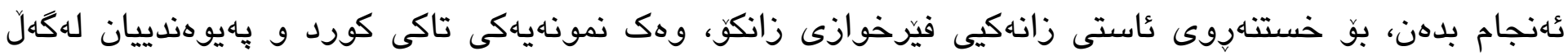

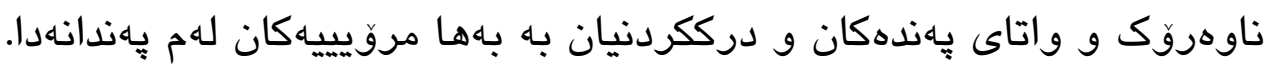

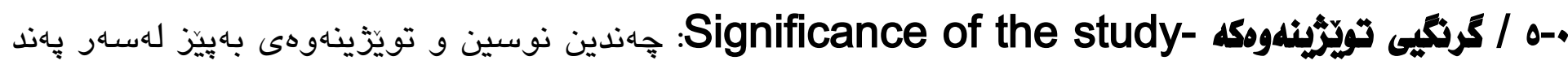

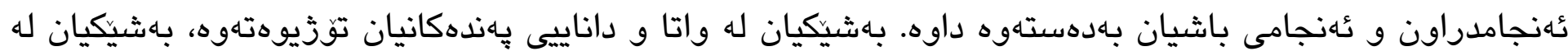

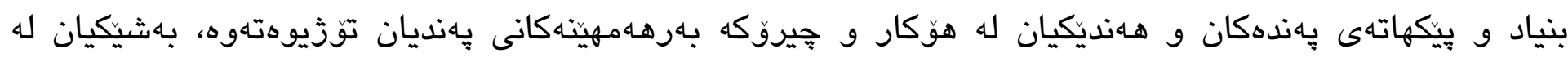

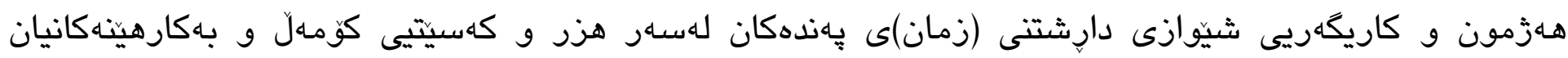

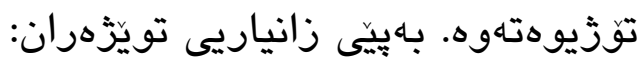

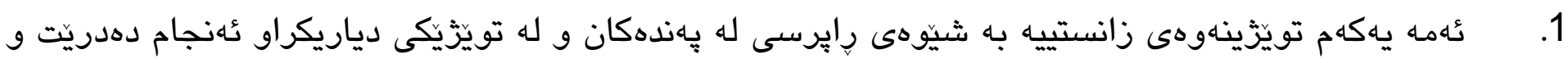

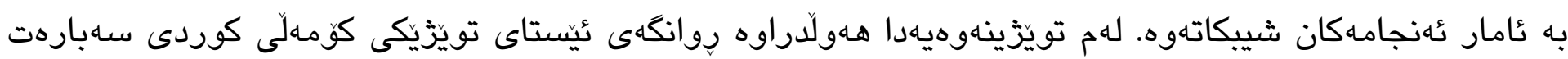

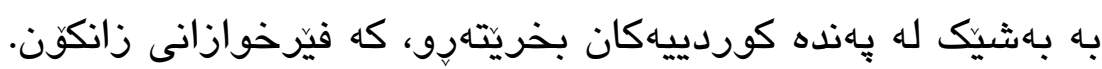

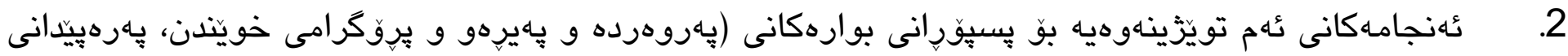

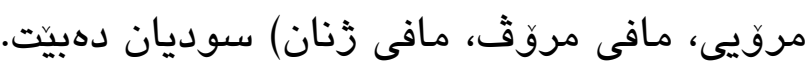




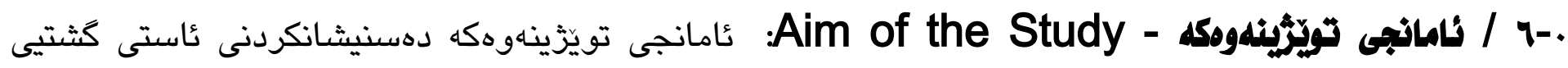

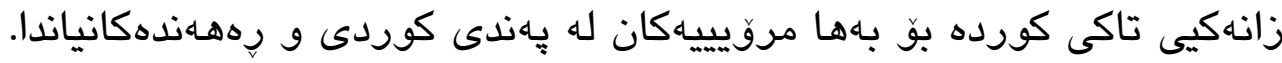

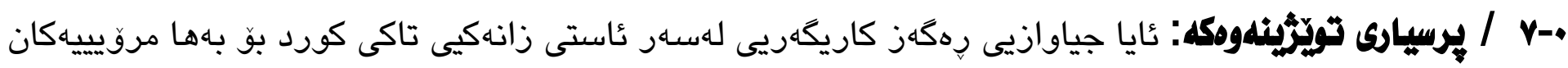
له يهندى كورديدا هـهيه؟

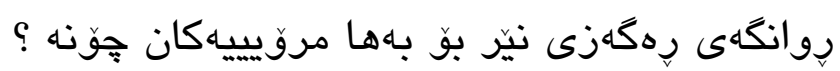

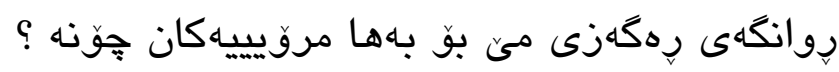

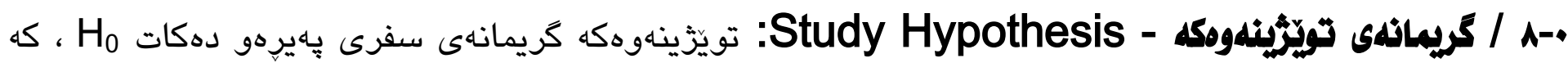

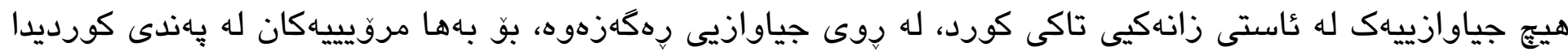

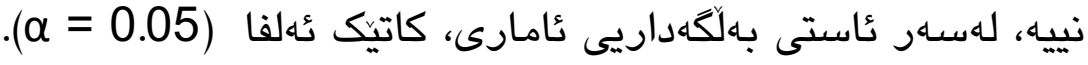

\section{ه a-•}

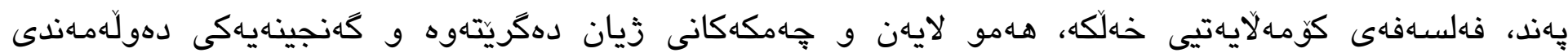

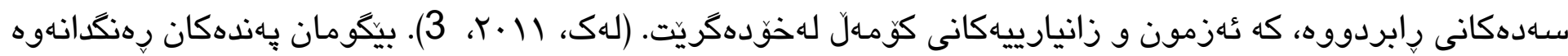

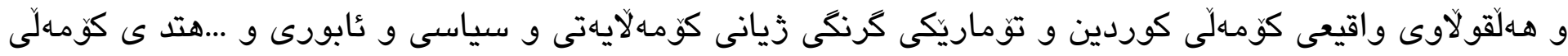

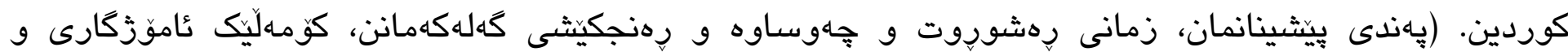

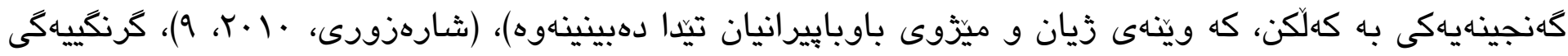

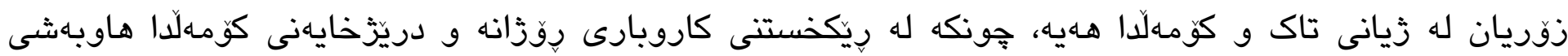

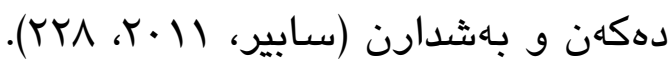

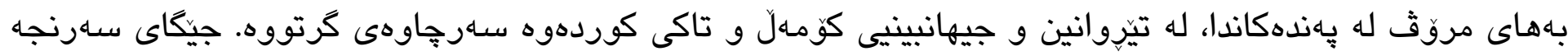

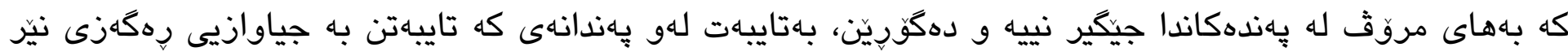

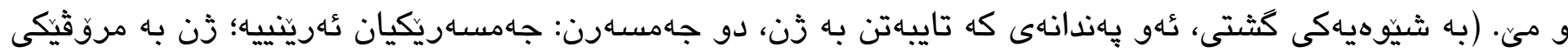

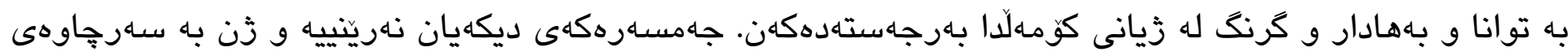

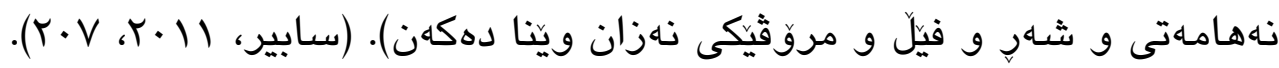

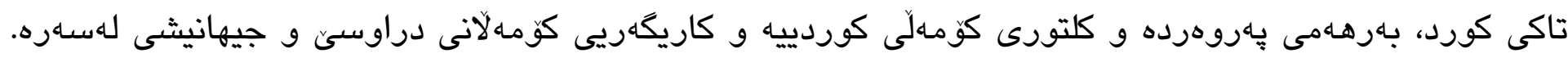

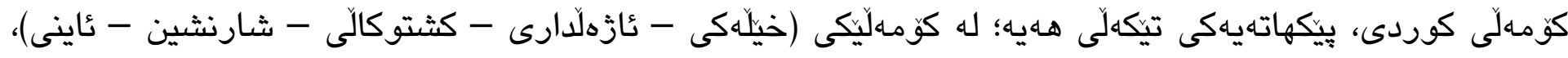

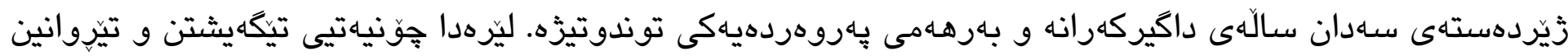

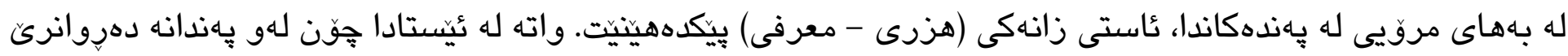

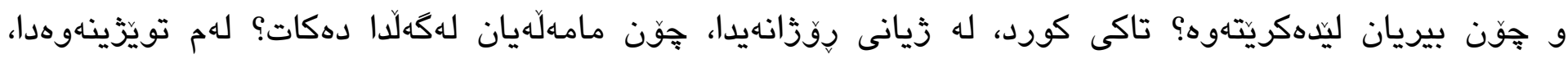

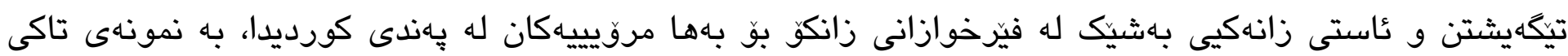
كورد دهخريتهاِو. 


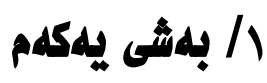

\section{ا-• / ناسانلدى زاراومكان - definition of the Terms}

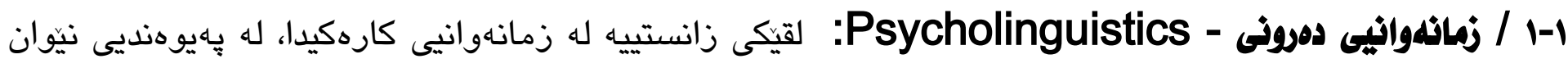

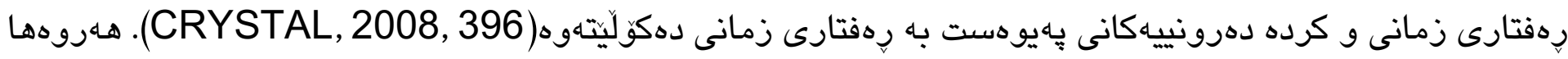

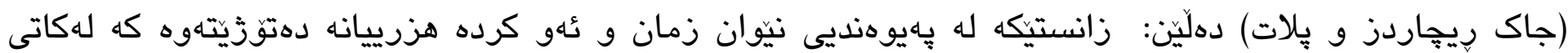

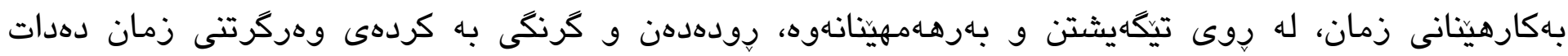

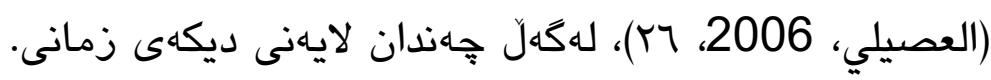

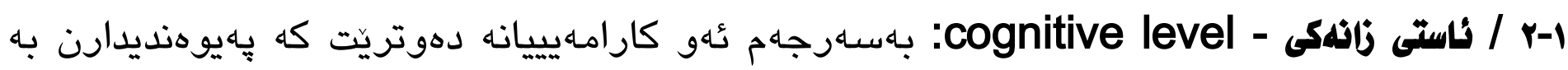

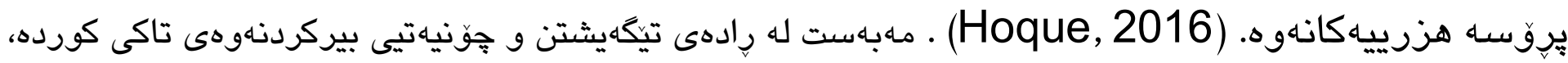
كه فيّرخوازى زانكو نمونهيه كه له تاكى كورد.

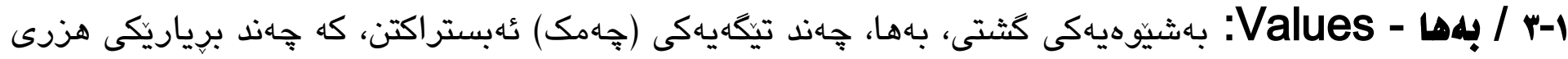

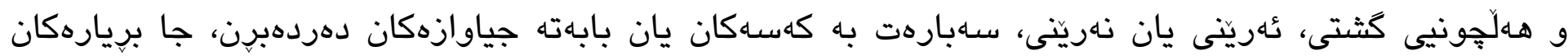

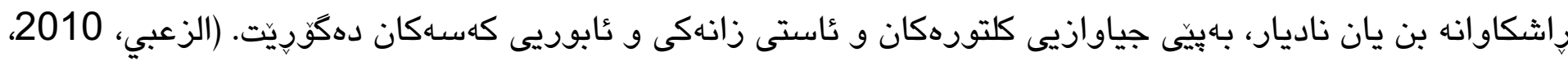

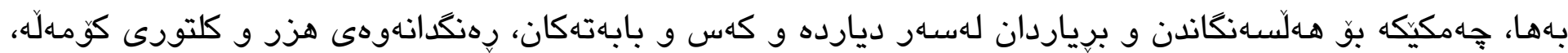

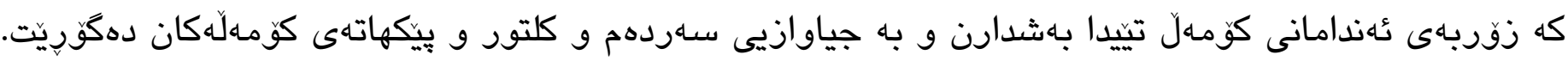

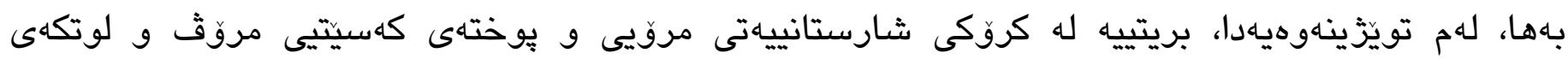

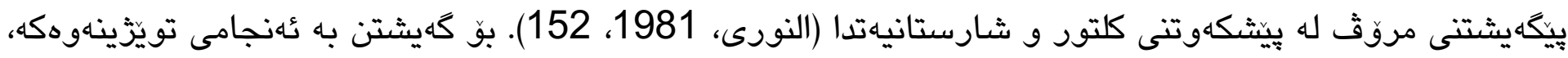

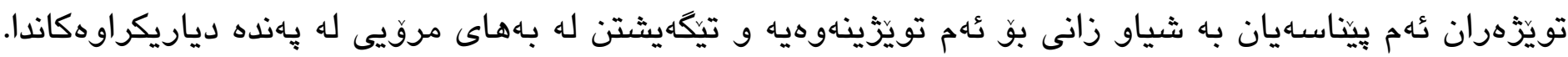

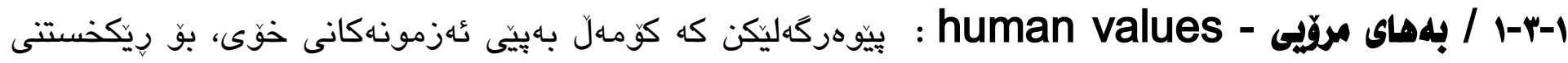

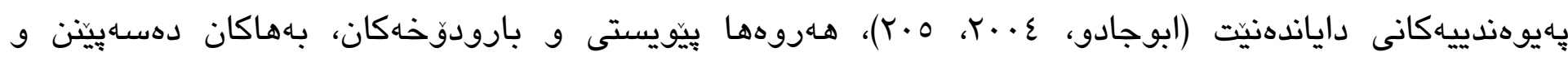

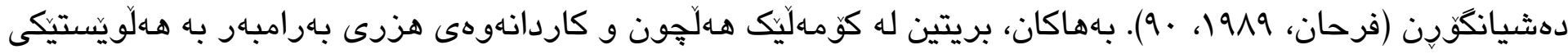

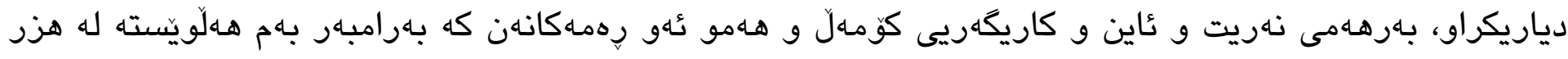

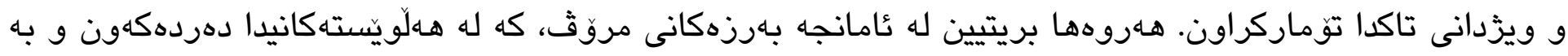

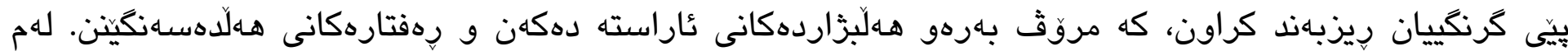

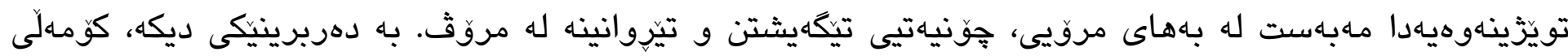

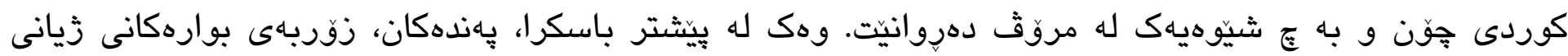

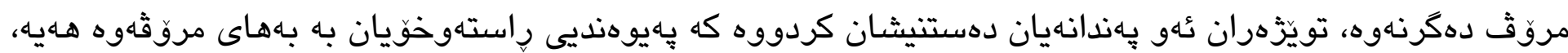

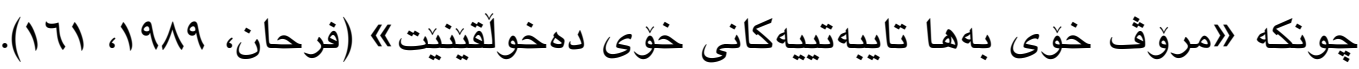




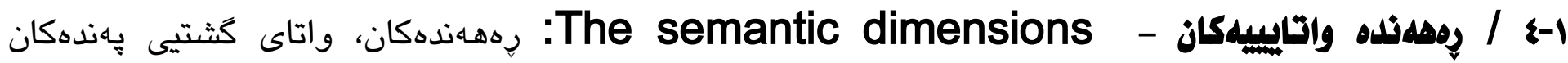

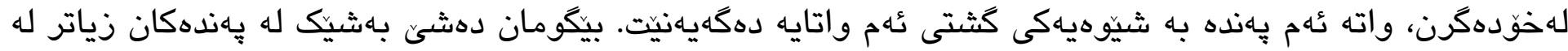

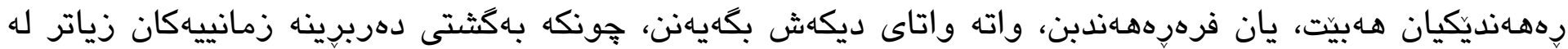

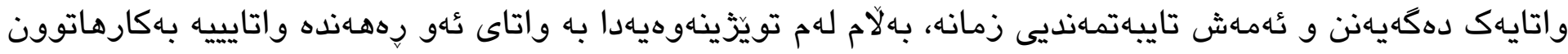

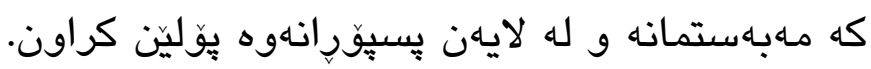

1. متماثل - Confidence : بروابونه به تواناى ئهنجامدانى رهفتار به شيّوهيهكى دروست و كونجاو و كارا.

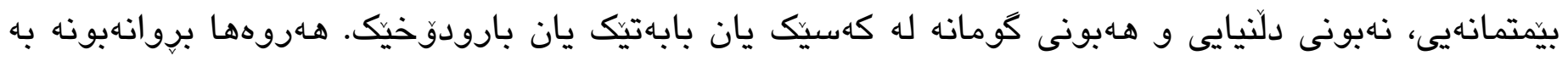

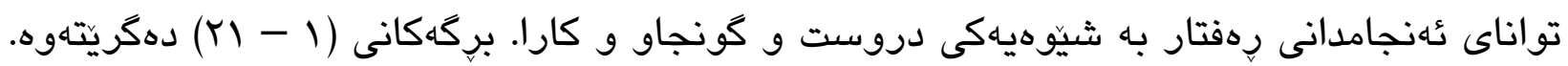

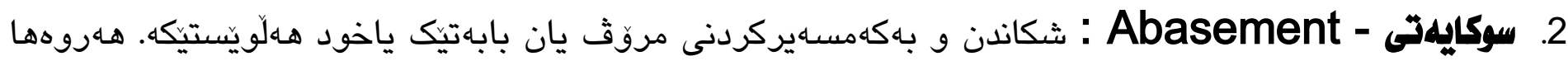

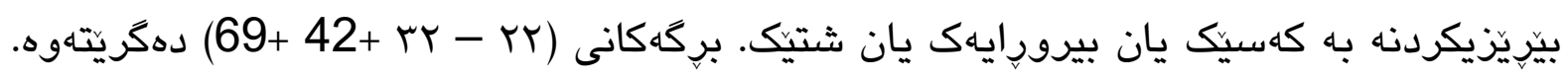

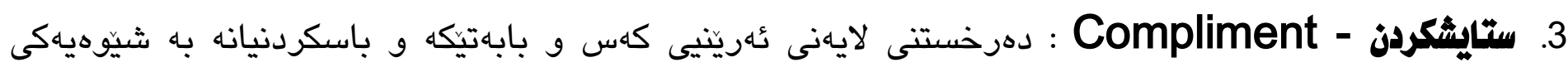

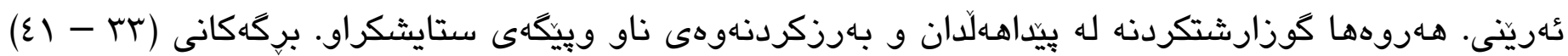
دهكريتهوه.

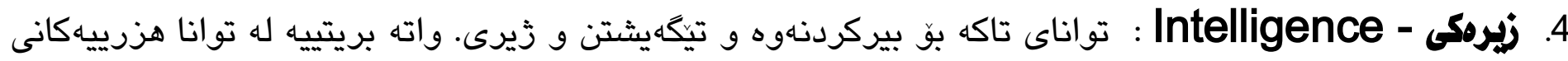

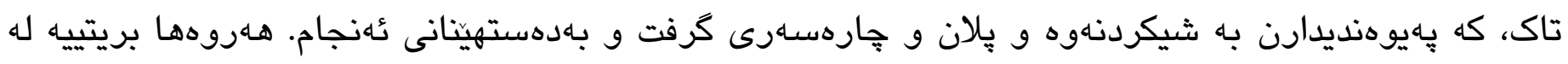

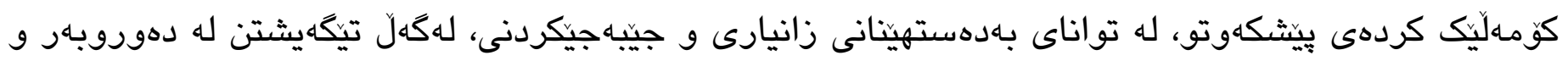

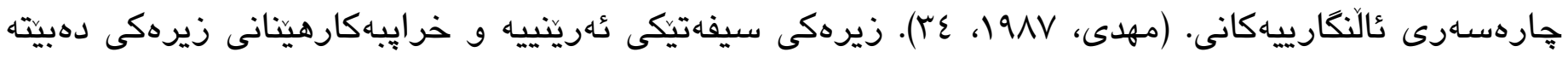

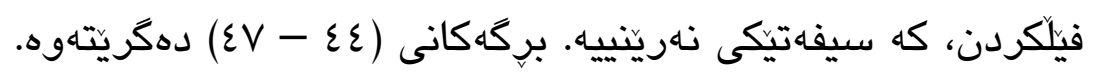

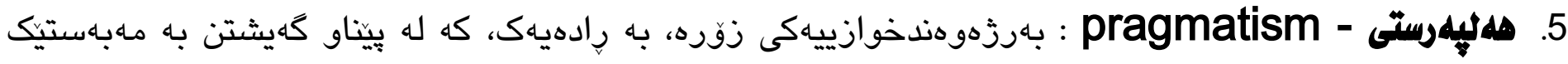

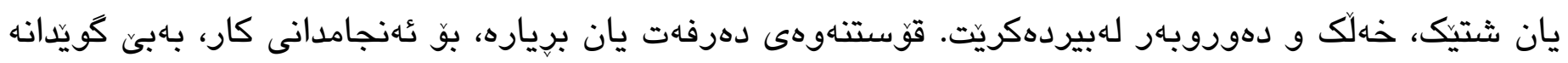

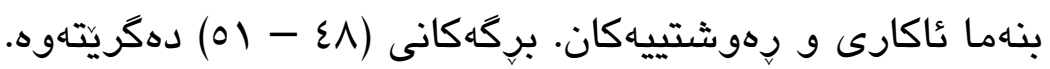

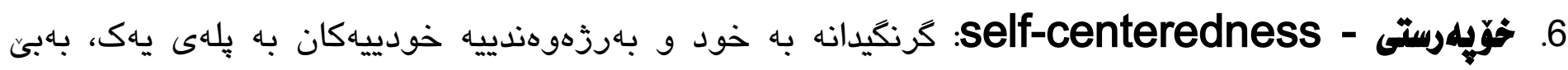

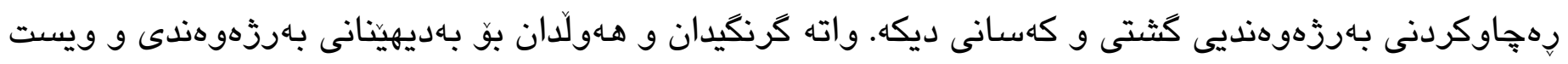

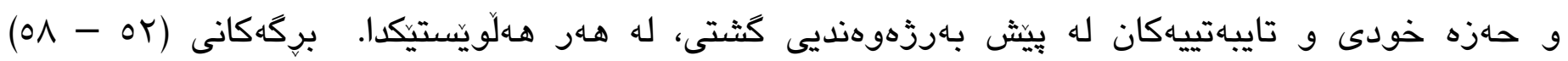

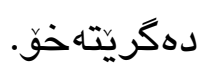

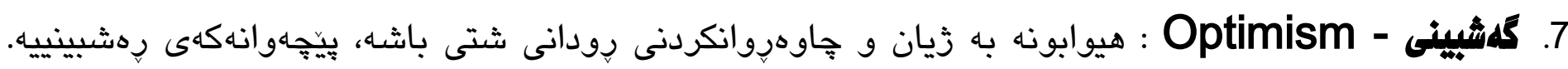

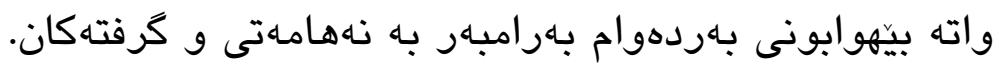

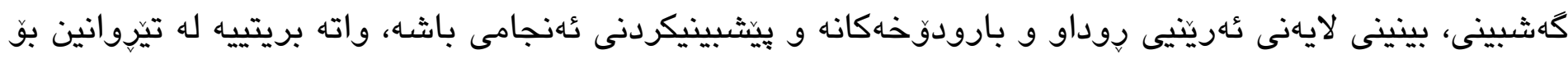

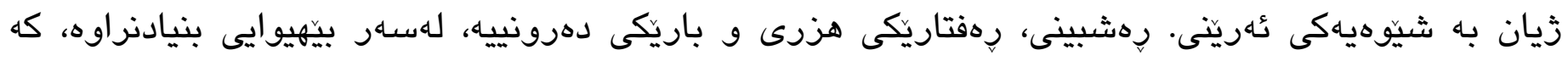

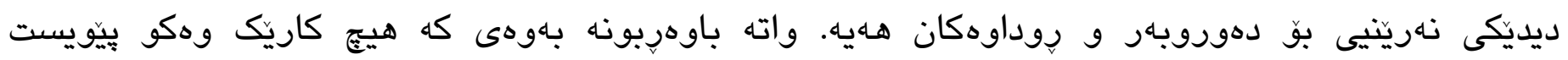

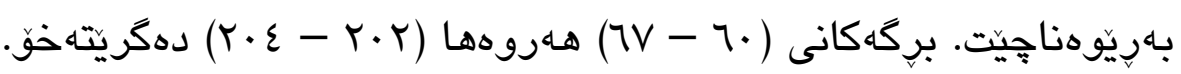




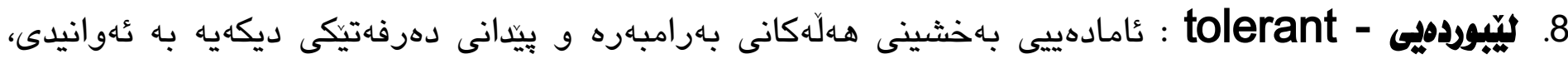

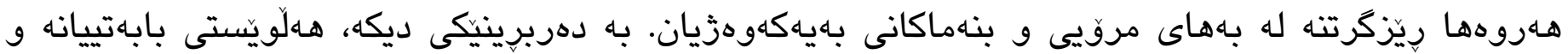

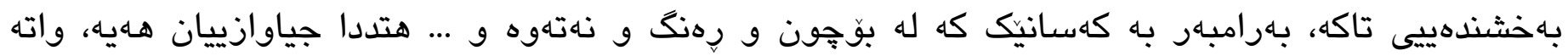

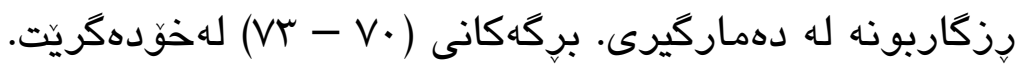

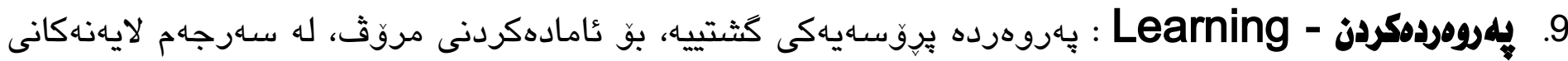

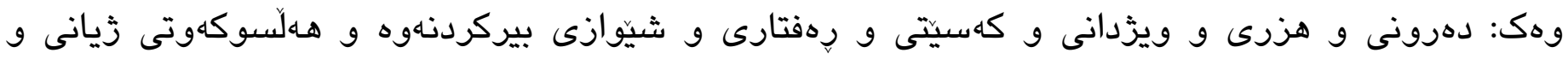

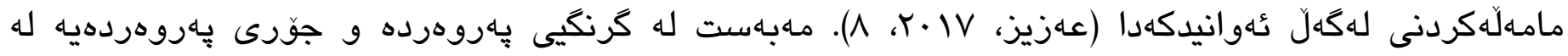

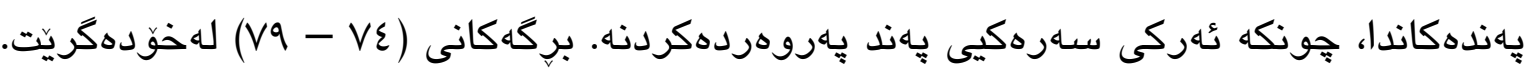

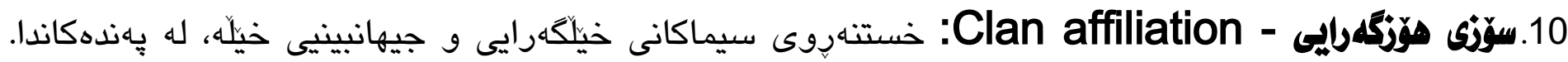

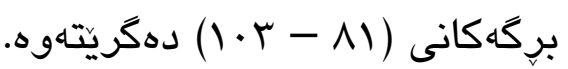

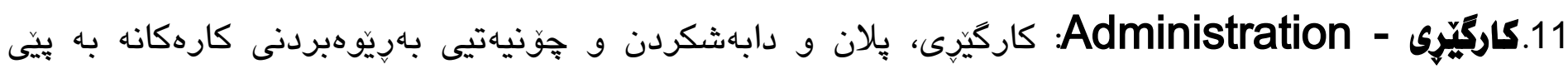

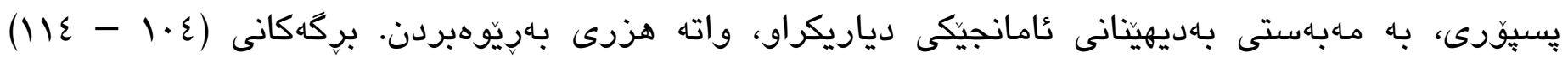

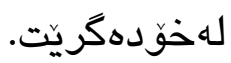

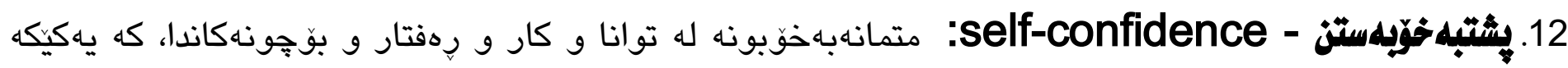

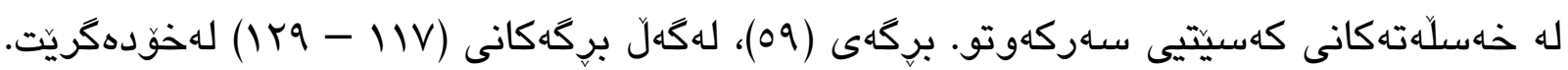

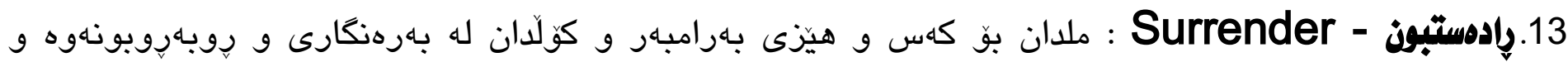

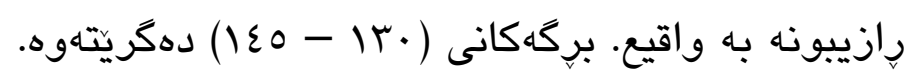

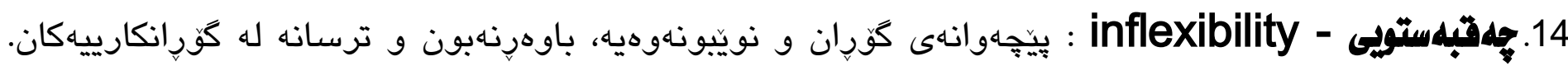

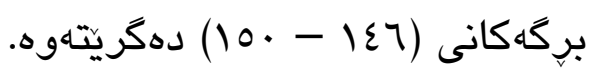

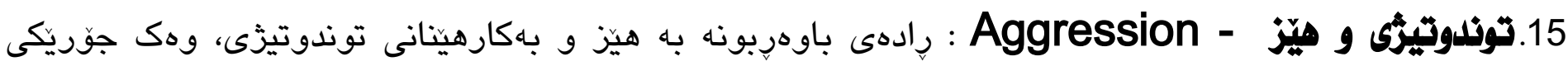

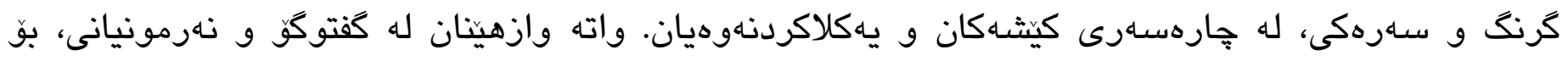

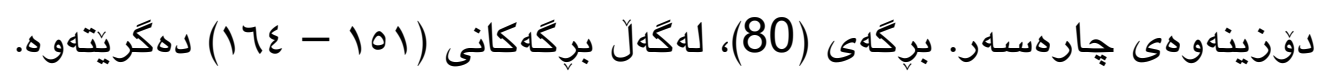

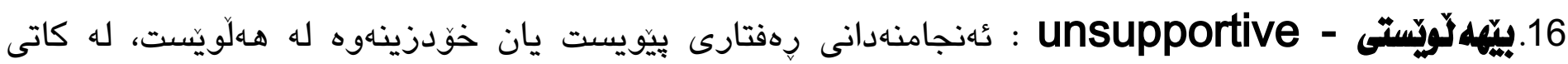

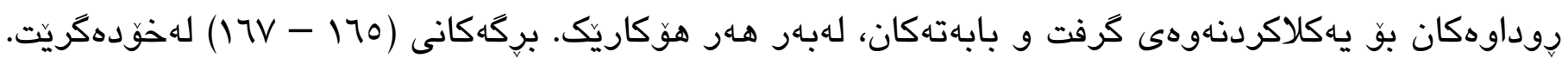
17.زانيز - Seeking knowledge : كرنكيدان به زانين و بهدواداجهون بوّ بهدهستهينانى زانيارى و هوَكارى

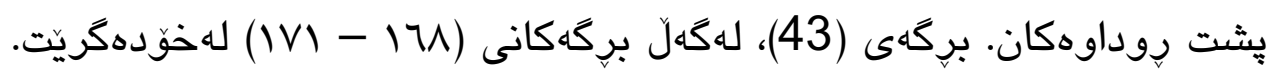

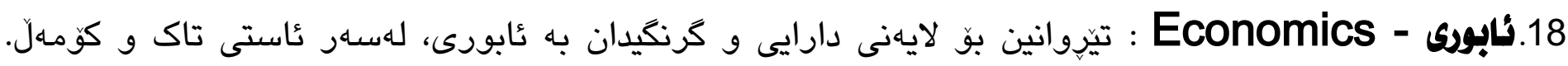

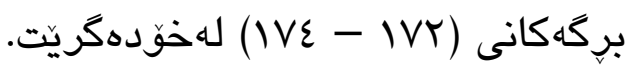

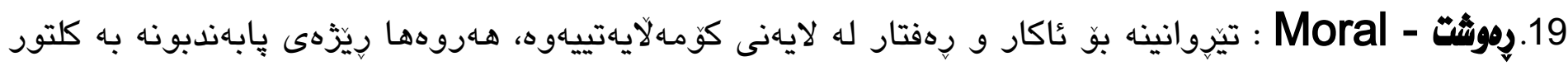

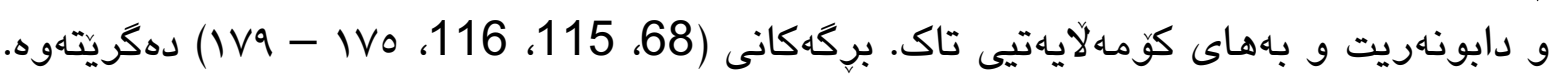

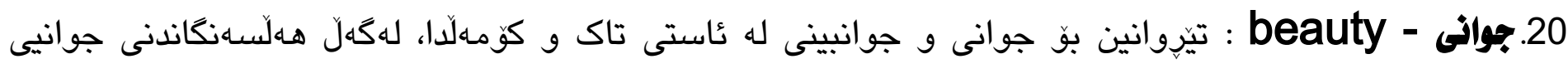

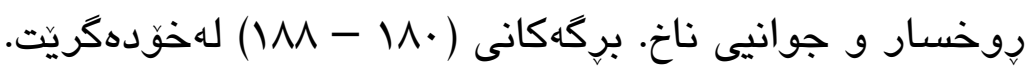




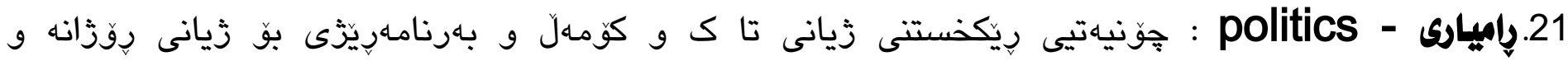

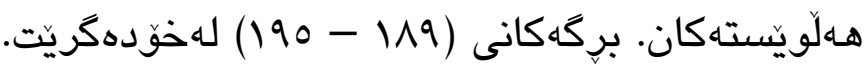

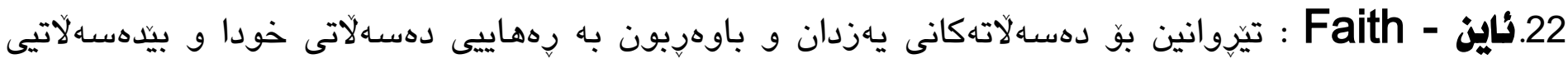

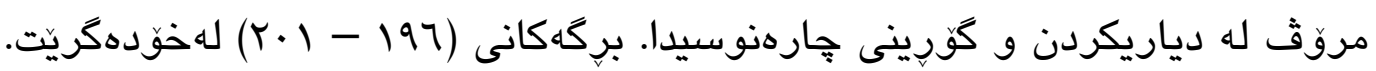

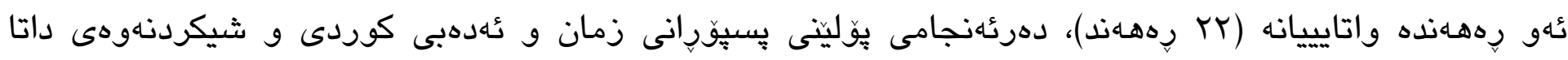

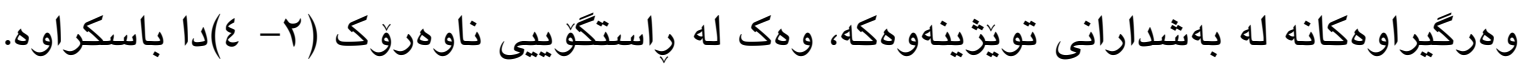

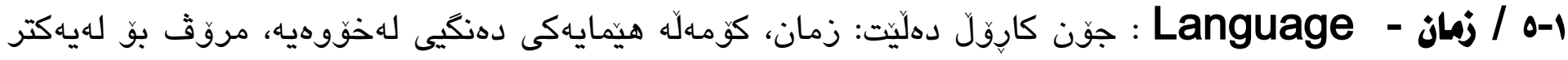

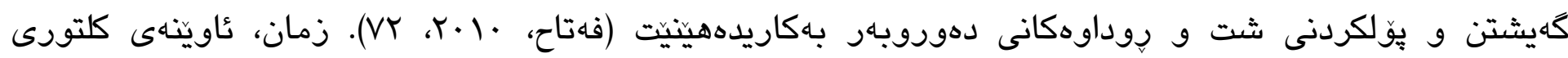

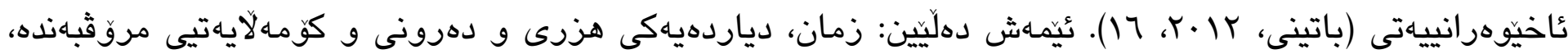

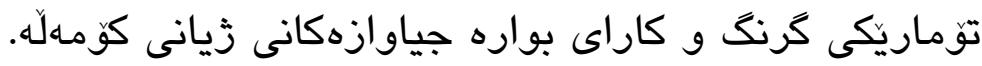

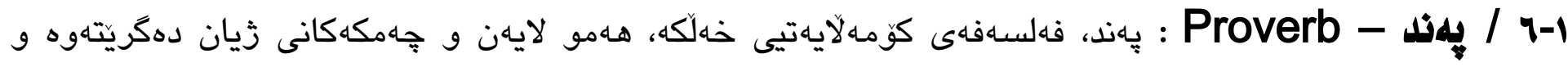

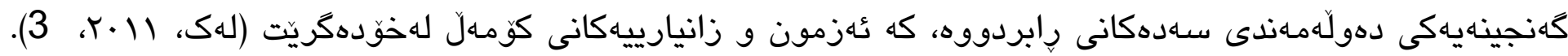

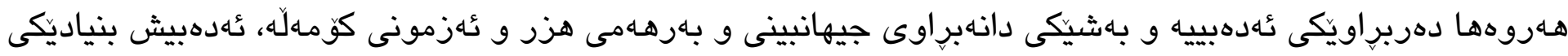

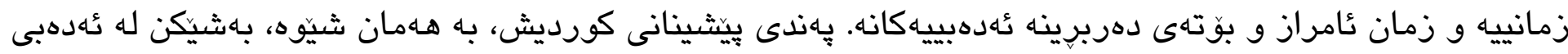

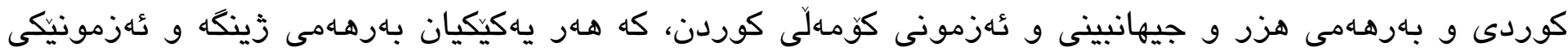

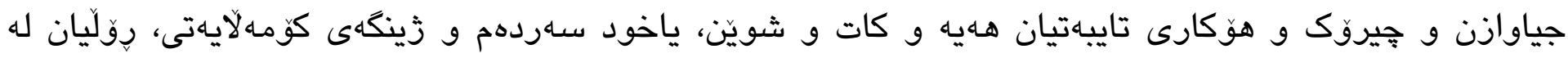

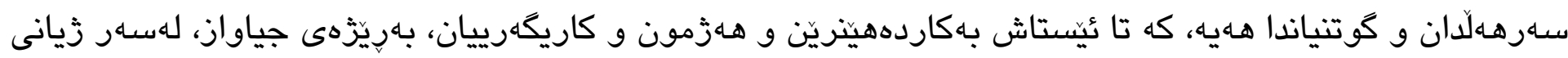

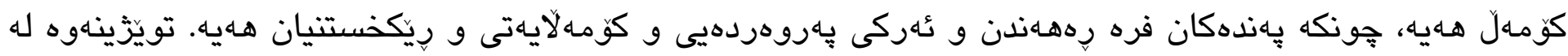

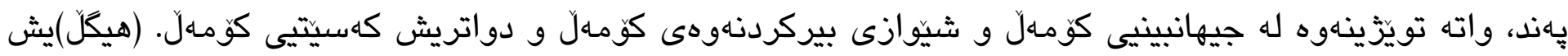

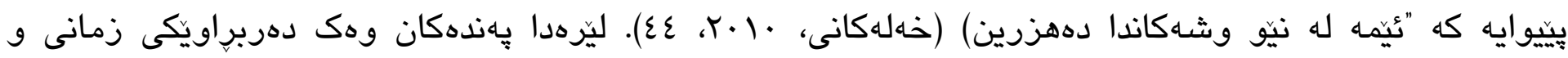

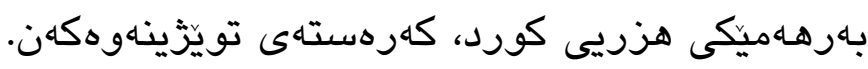

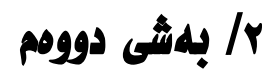

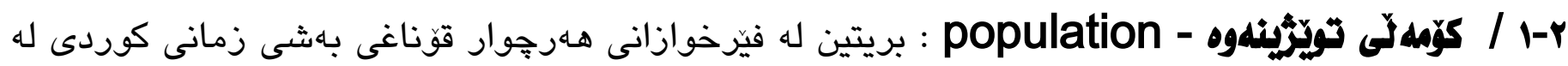

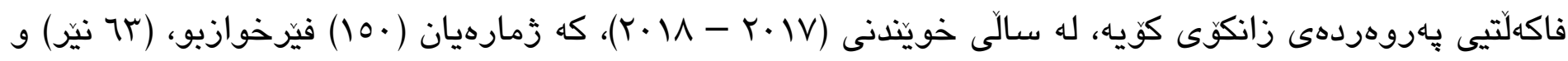

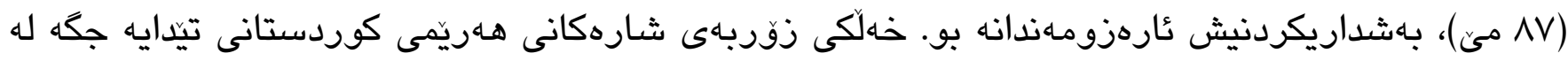

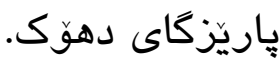

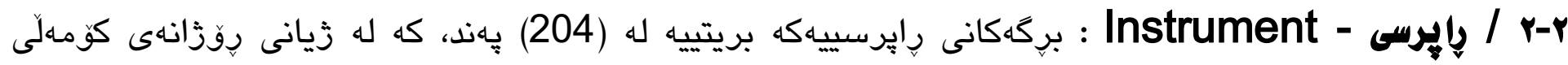

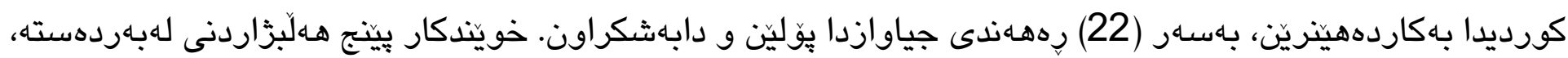

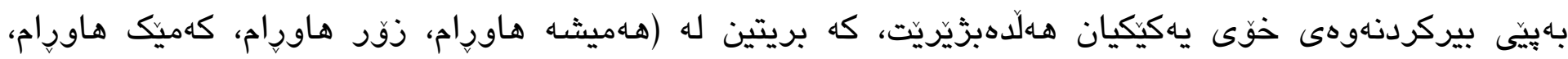
هاورانيم، هـاركيز هاوريا نيم). 


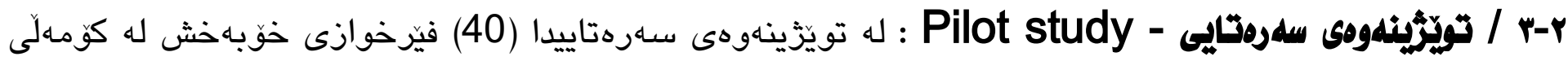

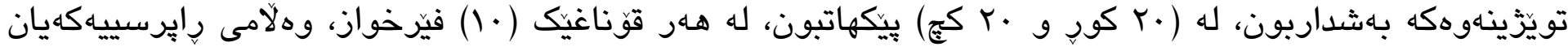

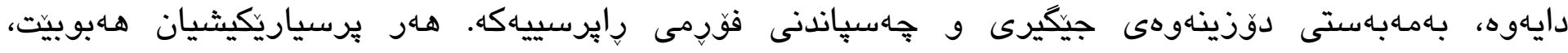

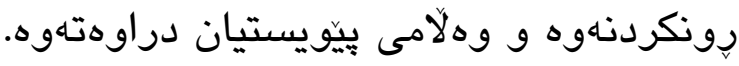

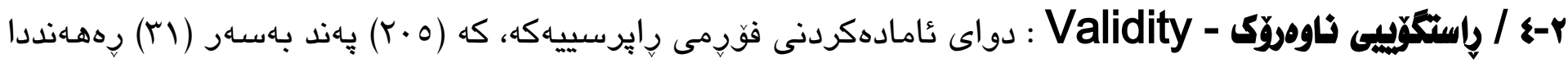

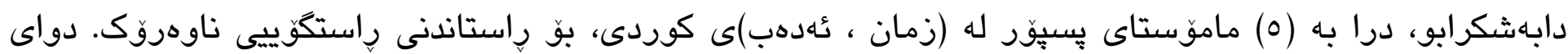

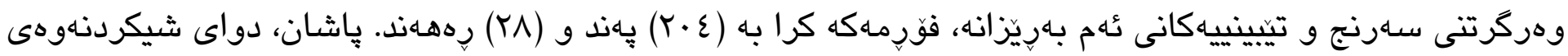

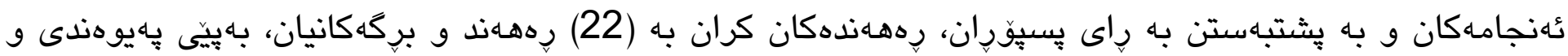

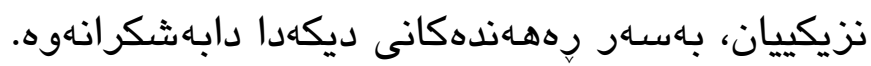

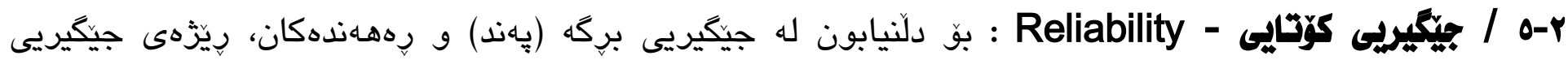

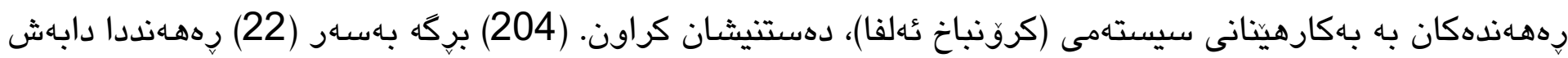

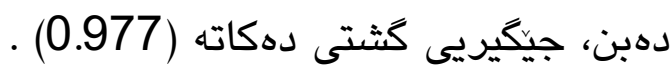

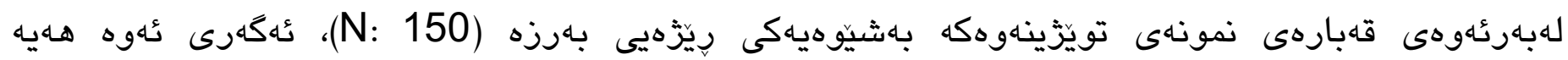

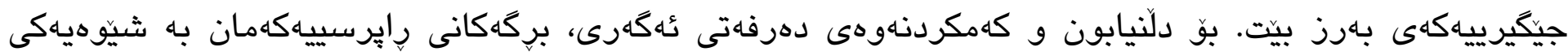

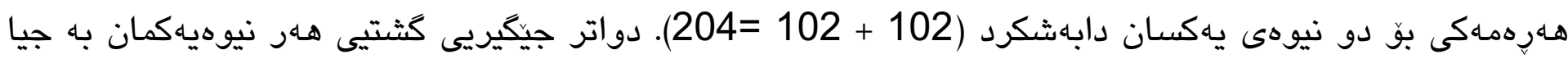

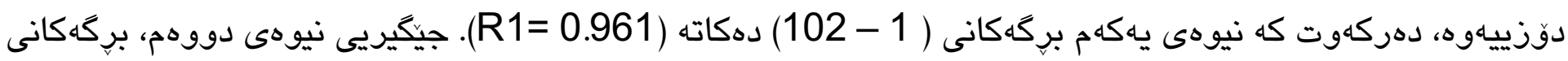

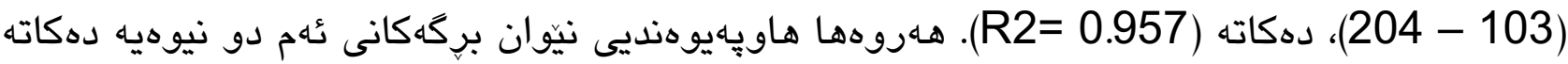

Spearman Brown Coefficient, $r=+0.890$

ختثلى زماره (1)

\begin{tabular}{|c|c|c|c|}
\hline \multicolumn{4}{|c|}{ 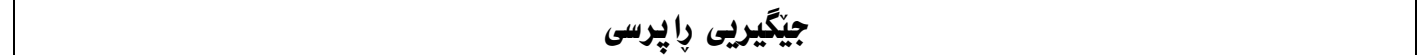 } \\
\hline \multirow[t]{5}{*}{ Cronbach's Alpha } & \multirow[t]{2}{*}{ Part 1} & Value & .961 \\
\hline & & $\mathrm{N}$ of Items & 102 \\
\hline & \multirow[t]{2}{*}{ Part 2} & Value & .957 \\
\hline & & $\mathrm{N}$ of Items & 102 \\
\hline & \multicolumn{2}{|c|}{ Total $\mathrm{N}$ of Items } & 204 \\
\hline \multicolumn{3}{|c|}{ Correlation Between Forms } & .802 \\
\hline \multirow{2}{*}{$\begin{array}{l}\text { Spearman-Brown } \\
\text { Coefficient }\end{array}$} & \multicolumn{2}{|c|}{ Equal Length } & .890 \\
\hline & \multicolumn{2}{|c|}{ Unequal Length } & .890 \\
\hline \multicolumn{3}{|c|}{ Guttmann Split-Half Coefficient } & .883 \\
\hline
\end{tabular}


خثتهى زماره (2)

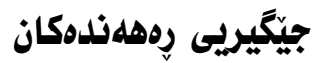

\begin{tabular}{|c|c|c|c|}
\hline جيكيرى & زُ بركه & رههـاندهكان & $j$ \\
\hline 0.827 & 21 & متمانه & .1 \\
\hline 0.832 & 13 & سوكايهتي & .2 \\
\hline 0.643 & 9 & ستايشكردن & .3 \\
\hline 0.784 & 4 & زيرهكى & .4 \\
\hline 0.6 & 4 & هـل هلِّرستى & .5 \\
\hline 0.745 & 7 & خوِّهِرستى & .6 \\
\hline 0.682 & 11 & كَهبينى & .7 \\
\hline 0.575 & 4 & لييوردديى & .8 \\
\hline 0.731 & 6 & بهروهردهكردن & .9 \\
\hline 0.871 & 23 & سوّزى هوَزگَرايى & .10 \\
\hline 0.692 & 11 & رينكخستن و كاركيّيرى & .11 \\
\hline 0.792 & 14 & بشتبه خوّبهستن & .12 \\
\hline 0.87 & 16 & رادهستبون & .13 \\
\hline 0.793 & 5 & جهاقبهستويى & .14 \\
\hline 0.853 & 15 & توندوتيزى و هيز & .15 \\
\hline 0.5 & 3 & بيُهه لَّيَستى & .16 \\
\hline 0.582 & 5 & زانين & .17 \\
\hline 0.586 & 3 & ئابورى & .18 \\
\hline 0.644 & 8 & ردوشت & .19 \\
\hline 0.741 & 9 & جوانى & .20 \\
\hline 0.674 & 7 & راميارى & .21 \\
\hline 0.729 & 6 & ئايين & .22 \\
\hline
\end{tabular}

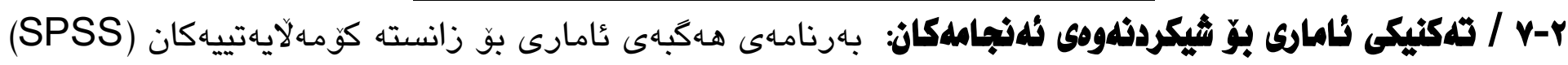
بـاركارهاتووه.

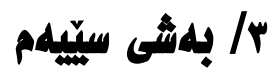

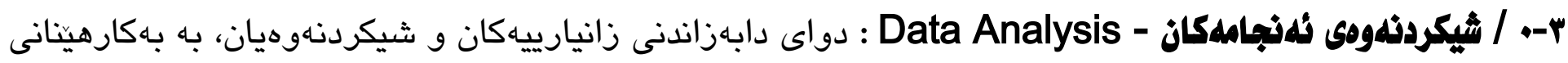

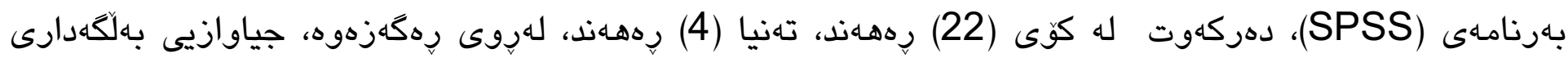

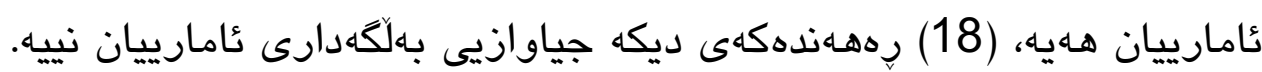

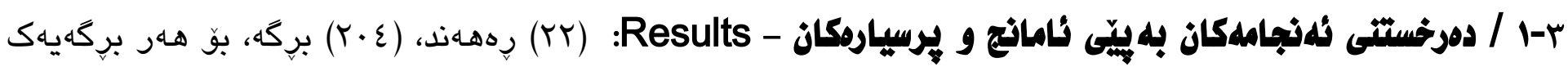

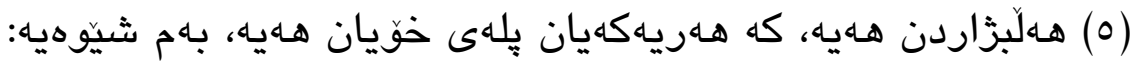




\begin{tabular}{|c|c|}
\hline عاست & هـالَّزَّاردنهان \\
\hline 1 & هـهريز هاورا نيم \\
\hline$r$ & هاورِا نيم \\
\hline r & كهميك هاورِام \\
\hline$\varepsilon$ & زقر هاورام \\
\hline 0 & هـهميشـه هاورِام \\
\hline
\end{tabular}

خثتهى زماره (4)

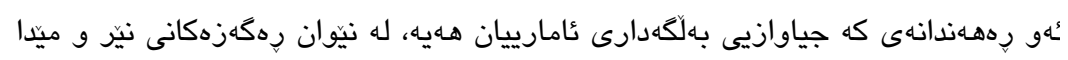

\begin{tabular}{|c|c|c|c|c|c|c|c|}
\hline رههـاند & رهكهز & تويَزينهوه & لناوهندMean & $\begin{array}{c}\text { Std. لادان له ناوهند } \\
\text { Deviation }\end{array}$ & $\begin{array}{c}\text { Std. Error } \\
\text { Mean }\end{array}$ & بلهاست لهانى بيّوهر & كأستى بهلكَهدارى \\
\hline \multirow[t]{2}{*}{ لمتمانه } & \multirow[b]{2}{*}{ 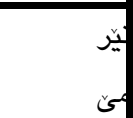 } & 58 & 69.48 & 11.30 & 1.49 & 3.30 & .000 \\
\hline & & 78 & 61.70 & 12.12 & 1.37 & 2.93 & .000 \\
\hline \multirow{2}{*}{ |زيردكى } & \multirow{2}{*}{ ليّن } & 62 & 13.82 & 3.22 & .40913 & 3.45 & .000 \\
\hline & & 82 & 10.39 & 4.00 & .44028 & 2.60 & .000 \\
\hline \multirow{2}{*}{ لمهلهِهرستى } & \multirow{2}{*}{ ليّن } & 62 & 15.46 & 2.36 & .29958 & 3.86 & .006 \\
\hline & & 83 & 14.24 & 2.83 & .31074 & 3.56 & .005 \\
\hline \multirow[t]{2}{*}{ |سوكايهتى } & \multirow{2}{*}{ ئين } & 56 & 79.2 & 10.55 & 1.41 & 2.58 & .000 \\
\hline & & 74 & 71.36 & 10.24 & 1.19 & 2.07 & .000 \\
\hline
\end{tabular}

ختهى زثماره (5)

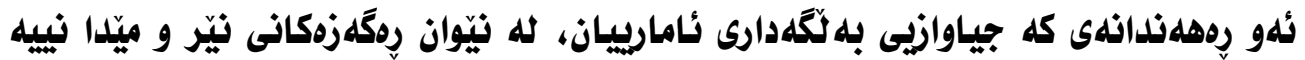

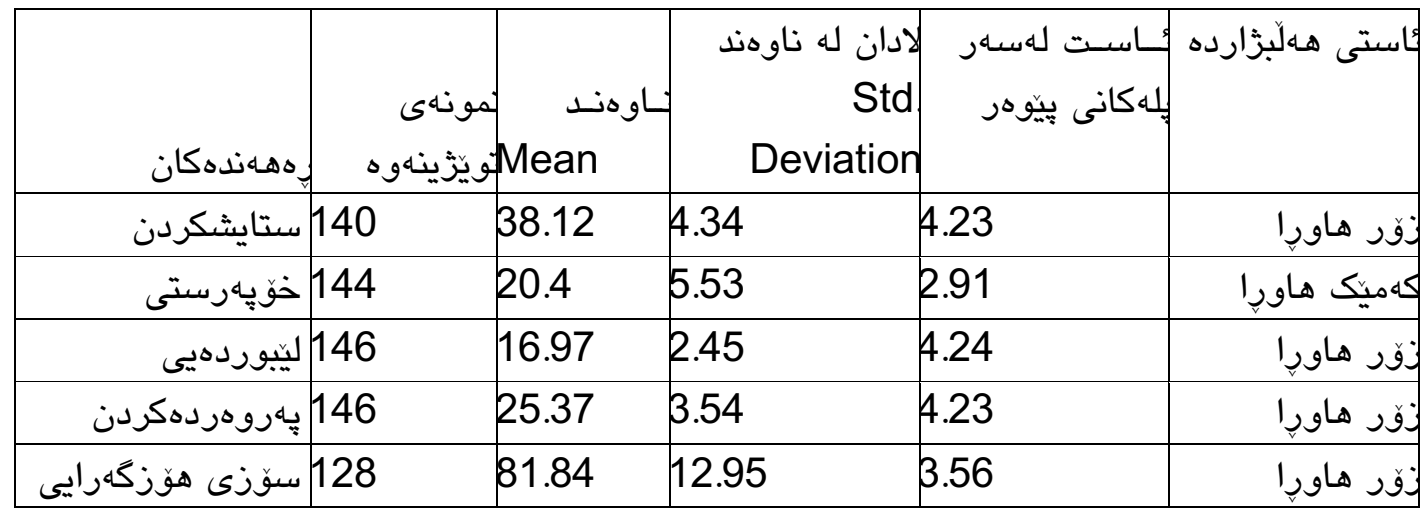




\begin{tabular}{|c|c|c|c|c|}
\hline 144|زانين & 20.9 & 2.98 & 4.18 & لِقر هاورا \\
\hline 141 يشتبه خوّبهستن & 59.5 & 6.43 & 4.25 & جورد هاورا \\
\hline 139 رهوشت & 33.3 & 4.09 & 4.16 & لِقر هاورا \\
\hline 132 توندوتيزى و هينز & 53.6 & 9.0 & 3.57 & لِور هاورا \\
\hline 141 كاركَيْيِى & 46.8 & 4.58 & 4.25 & لِقرد هاورٍا \\
\hline 130 رادهستبون & 59.1 & 10.25 & 3.7 & لِقور هاورا \\
\hline 149 |جهاةبه ستويى & 18.85 & 4.11 & 3.77 & لِقر هاورِا \\
\hline 146 بيّهاهلَويَستى & 11.22 & 2.43 & 3.74 & لِوَر هاورِ \\
\hline 148 |عابورى & 12.77 & 1.95 & 4.26 & لِور هاورا \\
\hline 143 جوانى & 37.42 & 5.66 & 4.16 & لِقور هاورا \\
\hline 143 راميارى & 30.49 & 3.32 & 4.35 & لِور هاورٍا \\
\hline 147 نعاين & 26.7 & 3.43 & 4.45 & لِقر هاورا \\
\hline 144 كَهشبينى & 44.24 & 5.24 & 4.0 & لِقرد هاورِ \\
\hline كَشتى & & & 4.0 & لِقور هاورِا \\
\hline
\end{tabular}

\begin{tabular}{|c|c|c|c|c|c|c|c|}
\hline 5 & 4.5 & 4 & 3.5 & 3 & 2.5 & 2 & 1.5 \\
\hline هـمنة & & زقد & & كهميك & & هاورا & \\
\hline هاورام & & هاورام & & هاورام & & نيم & \\
\hline
\end{tabular}

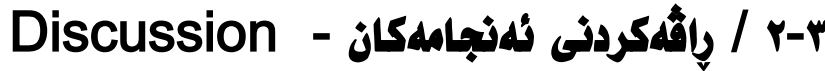

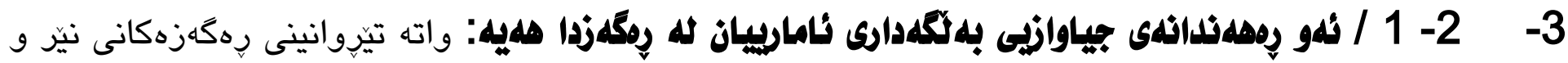

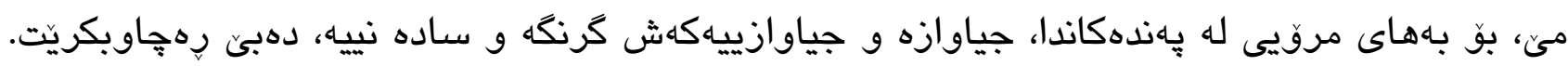

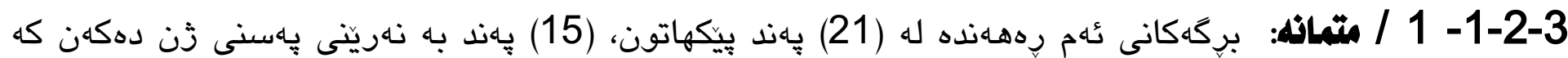

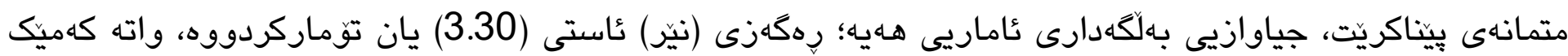

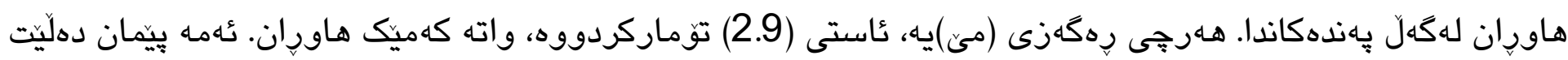

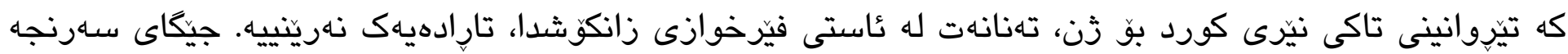

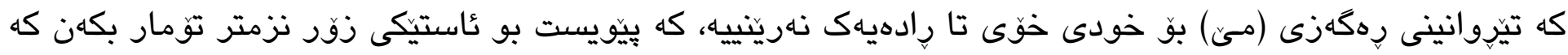

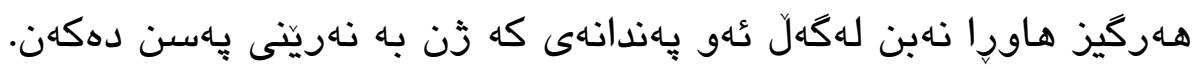




$$
\begin{aligned}
& \text { 1. بوك لهسهر زين، يارزق و يانسيب. }
\end{aligned}
$$

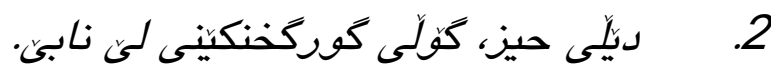

$$
\begin{aligned}
& \text { 3. كاريته له كفرى هـلْناستئ. } \\
& \text { 4. }
\end{aligned}
$$$$
\text { 5. }
$$$$
\text { 6. }
$$

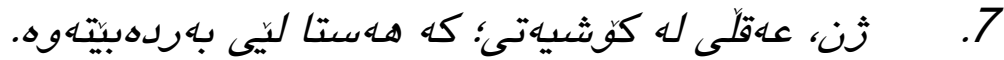

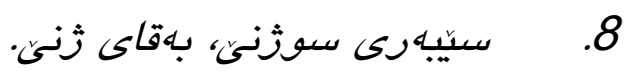$$
\text { 9. }
$$

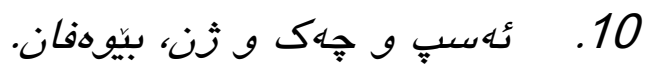

11.

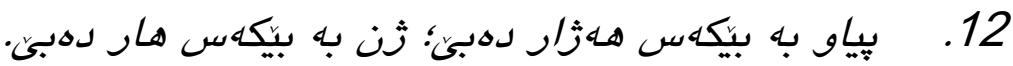

$$
\begin{aligned}
& \text { 13. خوشكى بيّيرا، خانيى بئى ئهستونله. }
\end{aligned}
$$

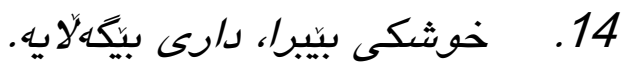

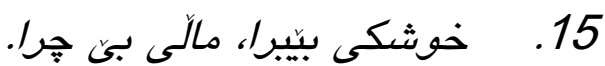

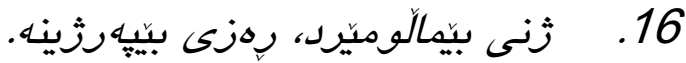

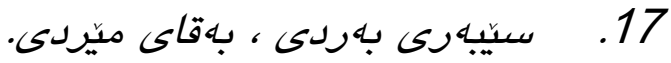

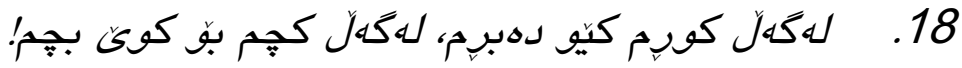

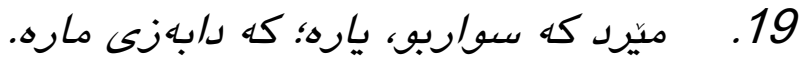

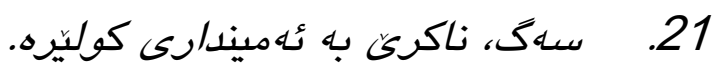$$
\text { 20. }
$$

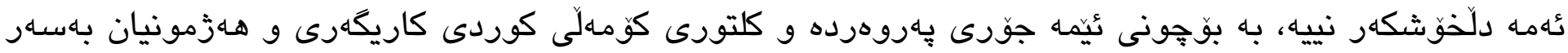

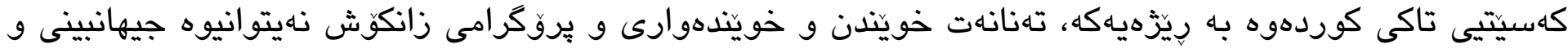

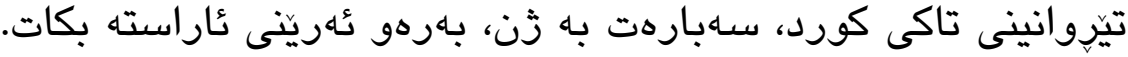

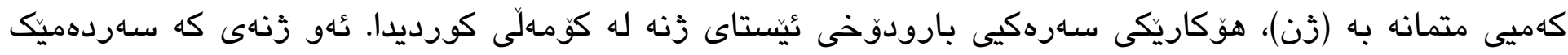

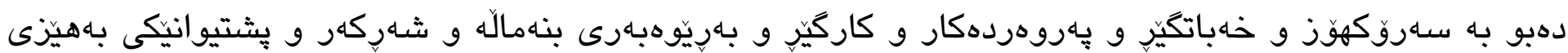

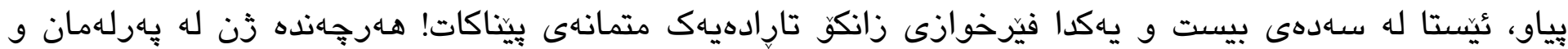

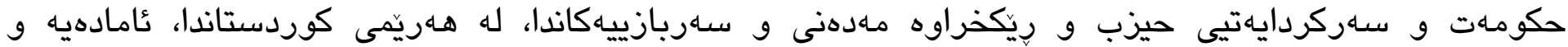
كاردهكات، كهجى هيشيتا نهبوته جيَّاى متمانها

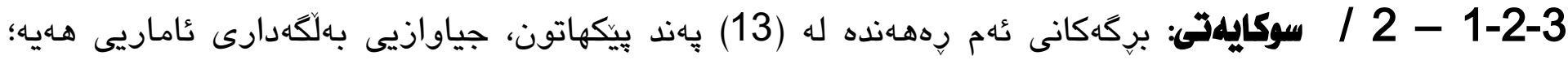

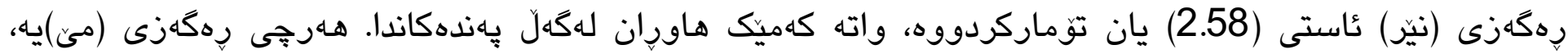

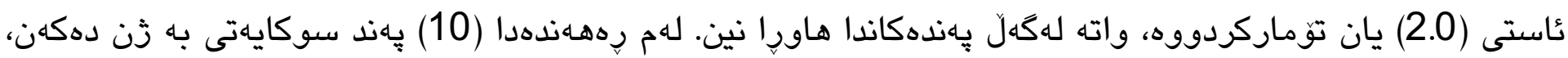

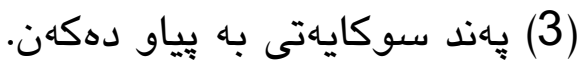




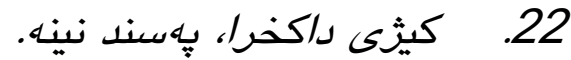

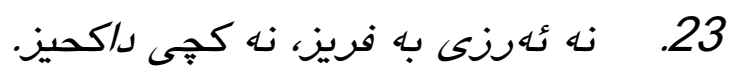

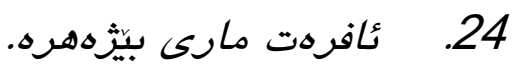

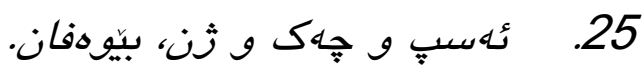

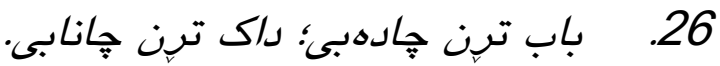

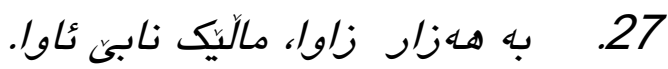

$$
\begin{aligned}
& \text { 28. اوا، كهرى خهزورانن. }
\end{aligned}
$$

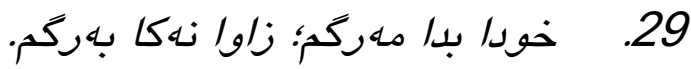

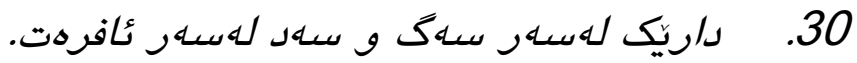

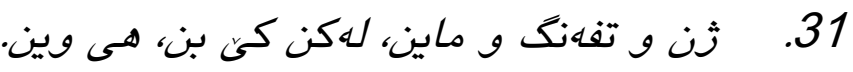

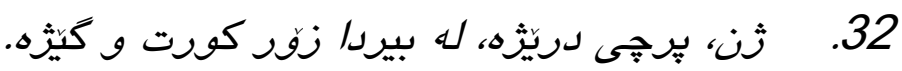

$$
\begin{aligned}
& \text { 42. }
\end{aligned}
$$

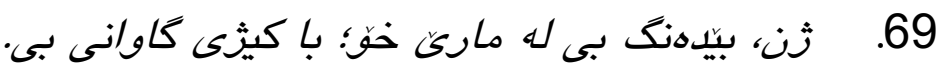

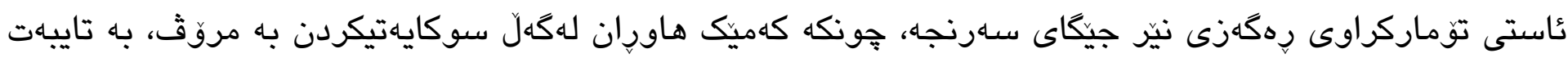

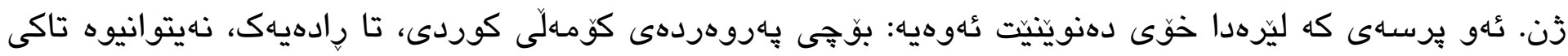

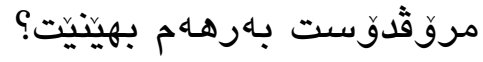

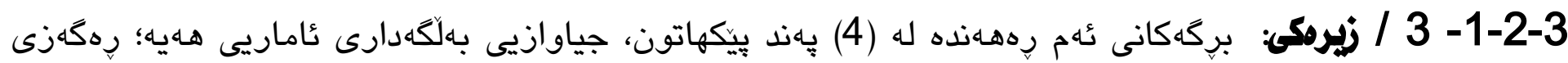

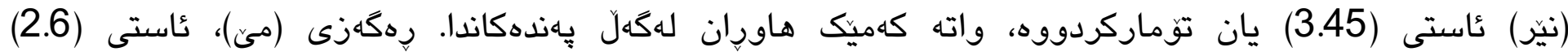

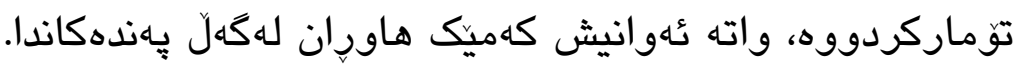

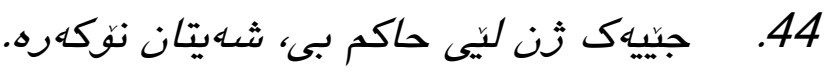

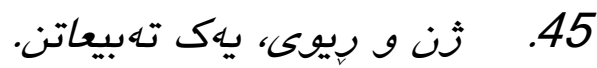

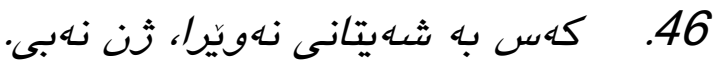

$$
\begin{aligned}
& \text { 47. مهكرى بيّوهزنان، ريّيوى لدهكاته كونان. }
\end{aligned}
$$

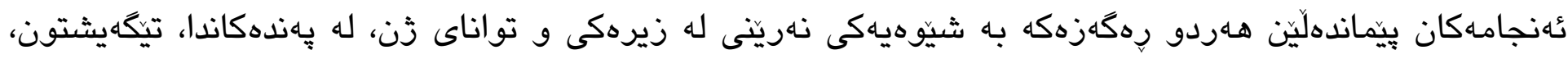
بوّيه ئهم ئاستهيان توّماركردووه.

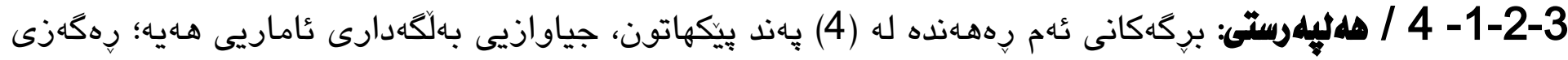

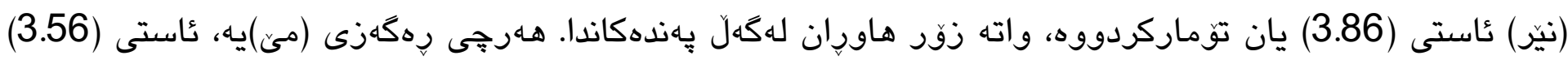

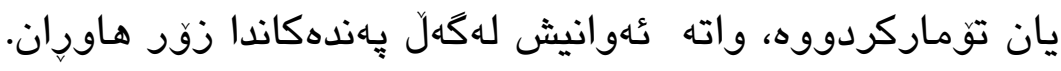

$$
\begin{aligned}
& \text { 48. ازرى بهناحازر مهده. لهسهر فرسهتى باز مهده. } \\
& \text { 49. } \\
& \text { 50. }
\end{aligned}
$$




$$
\text { 51 }
$$

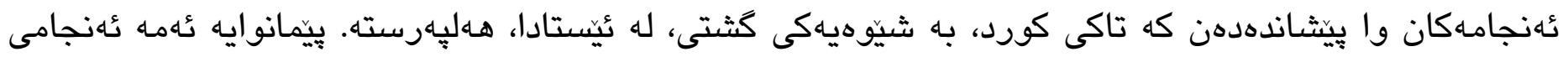

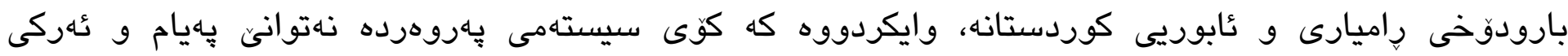

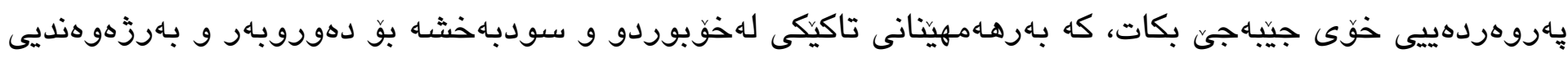

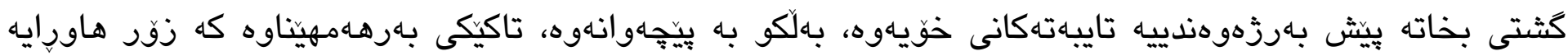

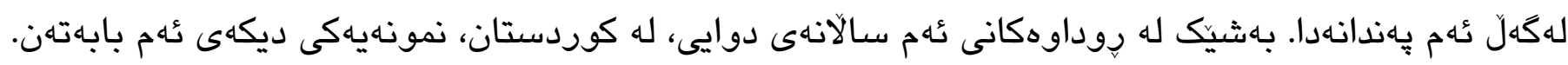

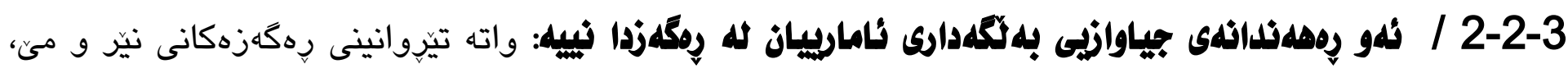
بوّ بـهاى مرقيى له يهندهاندا، يهكسانه.

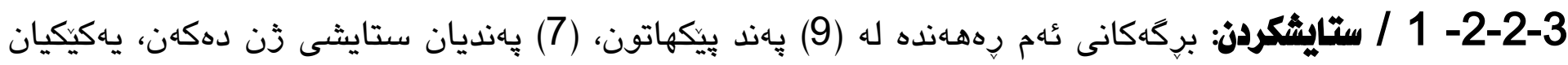

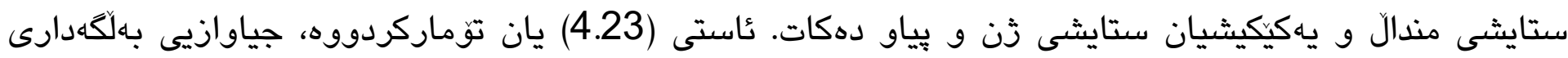

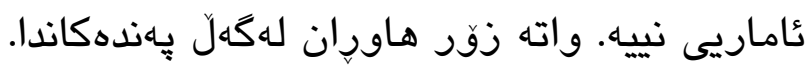

$$
\begin{aligned}
& \text { 33. رنت بمرى، ريست لدهبيتهوه خورى. }
\end{aligned}
$$

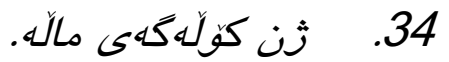

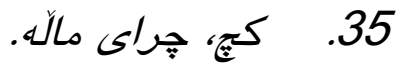

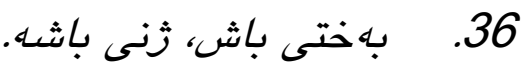

$$
\begin{aligned}
& \text { 37. }
\end{aligned}
$$

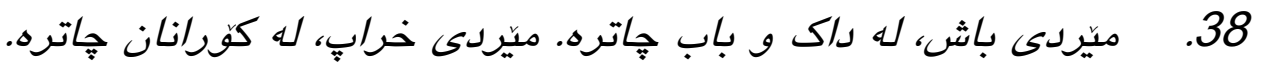

$$
\begin{aligned}
& \text { 39. }
\end{aligned}
$$

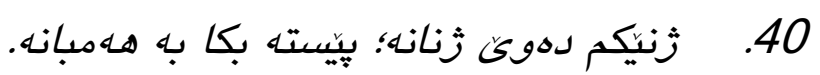

$$
\begin{aligned}
& \text { 41. }
\end{aligned}
$$

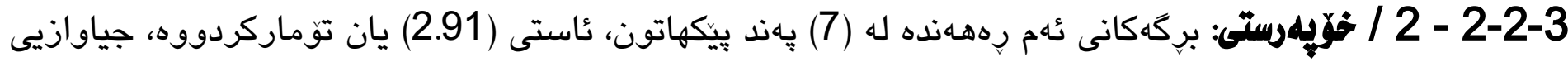

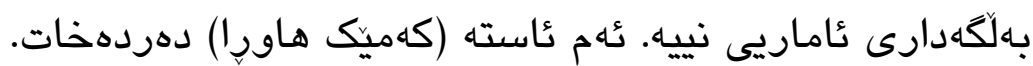

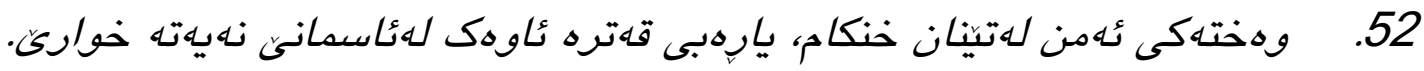

$$
\text { له من نهدهن لهبرام بلهن؛ وهدهز/نم لهرهشكهى كايى لدهدن. }
$$

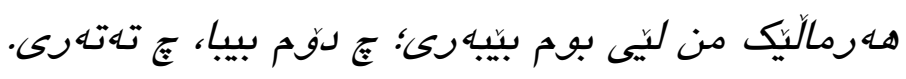

$$
\begin{aligned}
& \text { لنيا يِ (. . .) بي، بستهك لهمن لوربى. } \\
& \text { ئاكره سوره، له خُوم لوره. }
\end{aligned}
$$




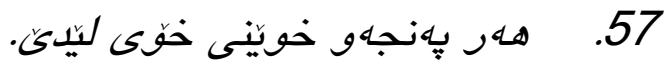

$$
\text { 58 }
$$

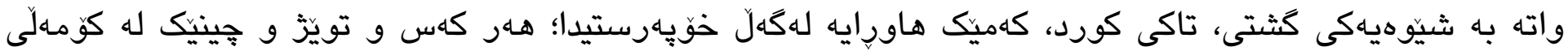

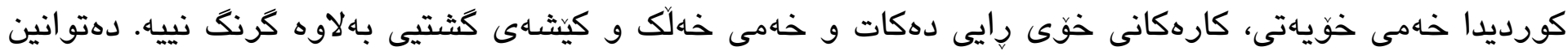

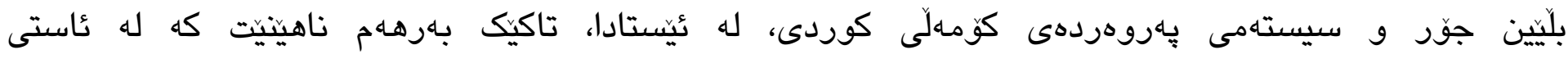

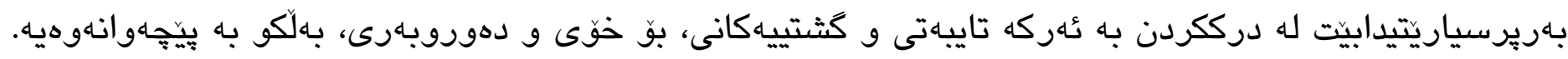

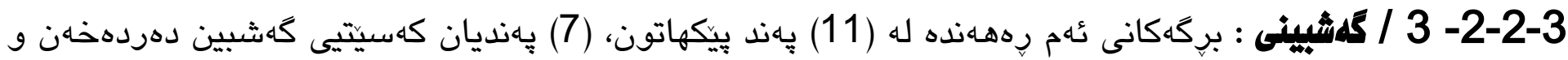

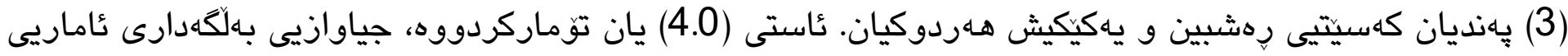

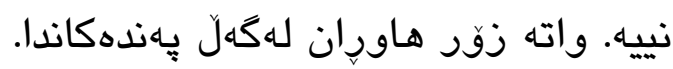

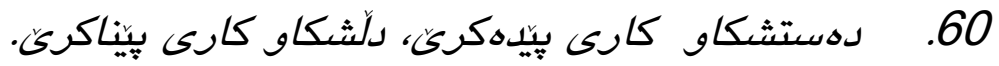

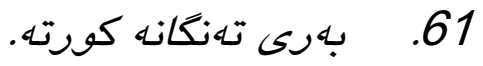

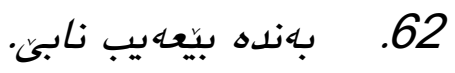

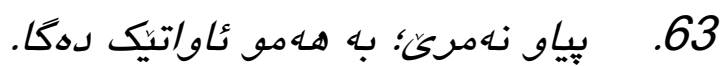

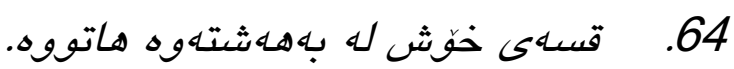

$$
\begin{aligned}
& \text { 65. }
\end{aligned}
$$

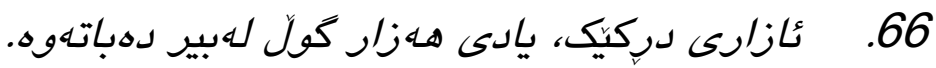

$$
\begin{aligned}
& \text { 67. }
\end{aligned}
$$

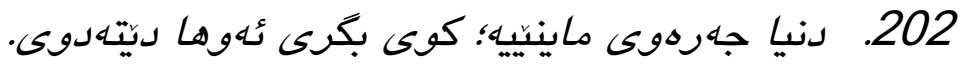

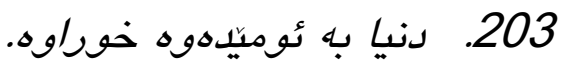

$$
\begin{aligned}
& \text { 204. سهرى دنيا به بوش نه نهيراوه. }
\end{aligned}
$$

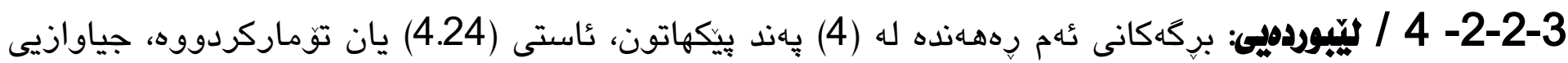

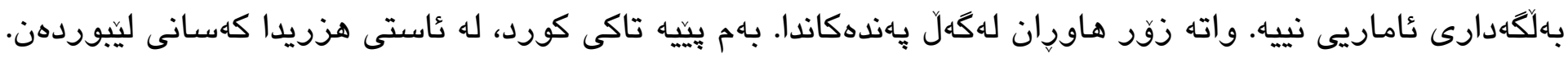

$$
\begin{aligned}
& \text { 70. بياودتى ها له بهخشينا، نهك له تقلّله سهندنا. } \\
& \text { 71. كه لدوزمنت كهوت؛ بيّيى بيا مهني. } \\
& \text { 72. كينه، دو مال ويّران دهكات. } \\
& \text { 73. خوين به خويّن ناشعَرحت. }
\end{aligned}
$$

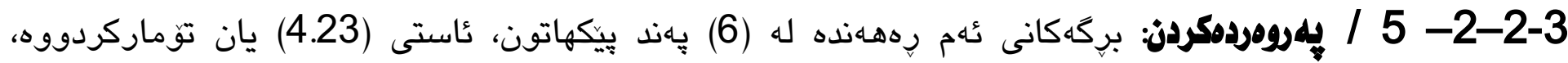

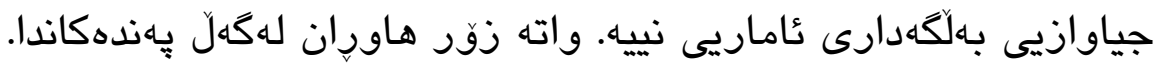




$$
\text { 74. }
$$

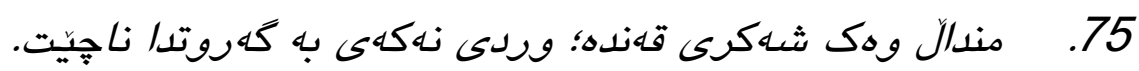

$$
\text { 77 } 7.76 .
$$

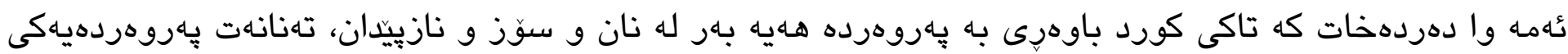

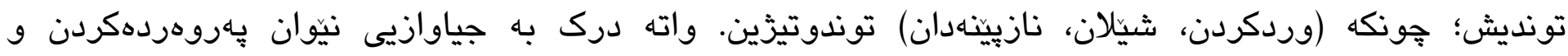
باهيَوكردن دهكات.

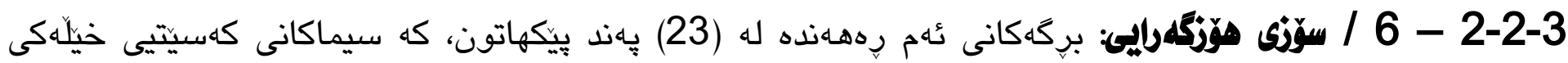

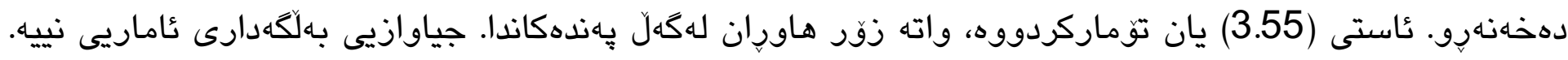

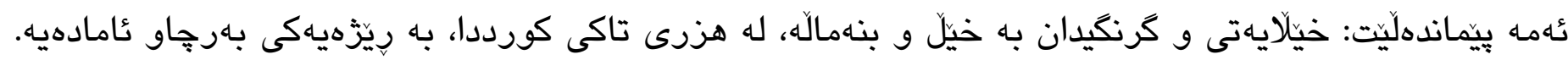

$$
\begin{aligned}
& \text { 81. } \\
& \text { 83. }
\end{aligned}
$$

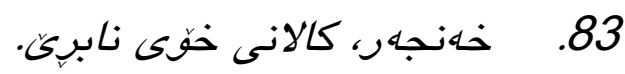

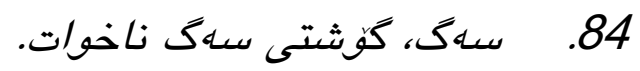

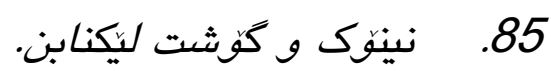

$$
\begin{aligned}
& \text { 86 } \\
& \text { 87. }
\end{aligned}
$$

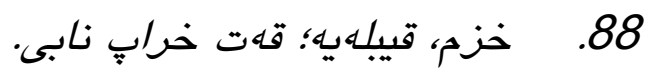

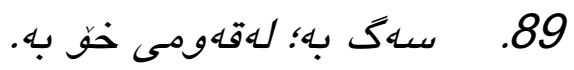

$$
\begin{aligned}
& \text { 90. }
\end{aligned}
$$

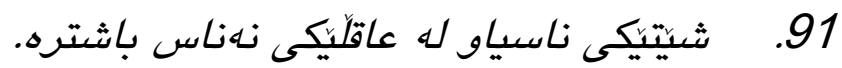

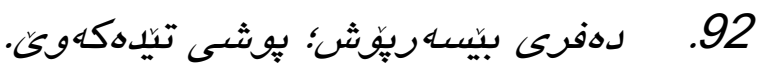

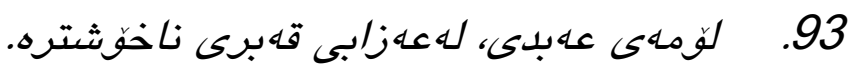

$$
\begin{aligned}
& \text { 94. }
\end{aligned}
$$

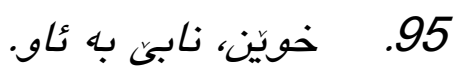

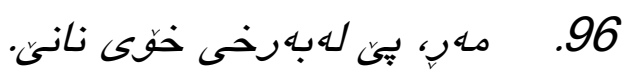

$$
\begin{aligned}
& \text { 97. }
\end{aligned}
$$

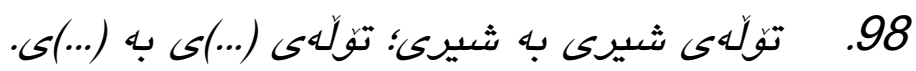

$$
\begin{aligned}
& \text { 100. } 98 \\
& \text { 100. له جيّي سندان، قوزهلقورته. له. }
\end{aligned}
$$




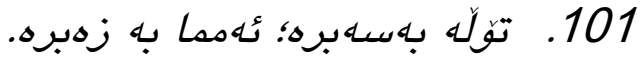

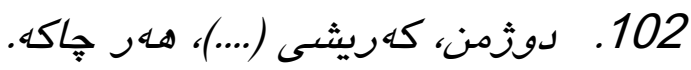

103. ت تقبهى كورك، مه ركه.

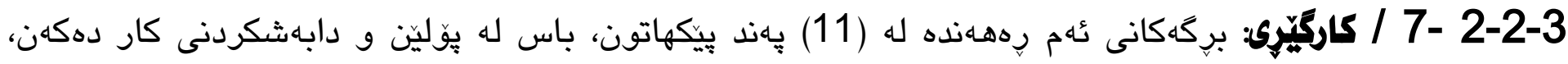

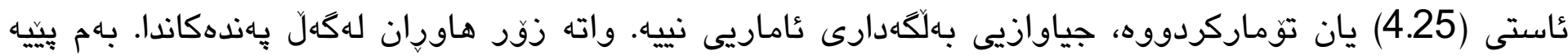

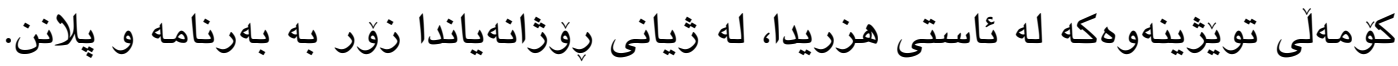

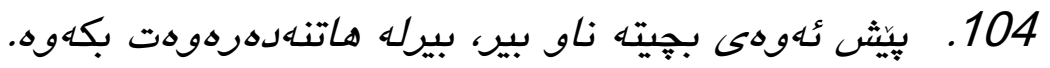

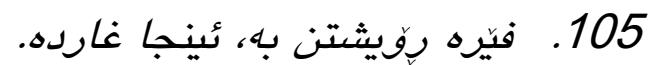

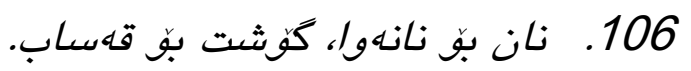

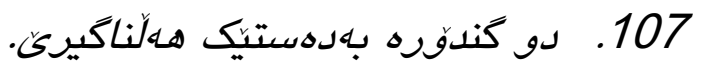

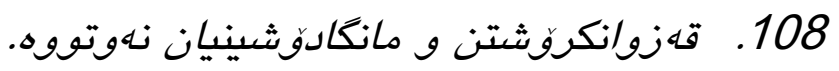

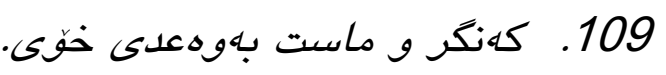

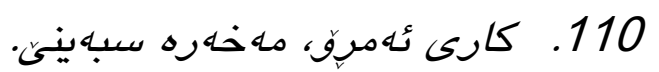

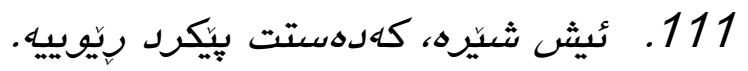

112. يش كهره، تاليينه خوريى نارِوا.

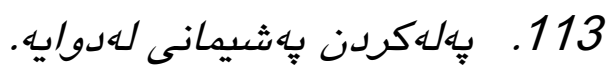

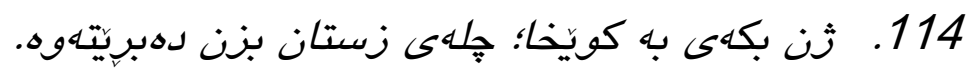

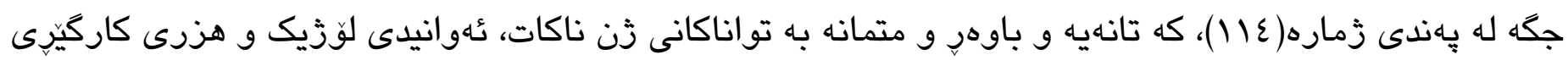

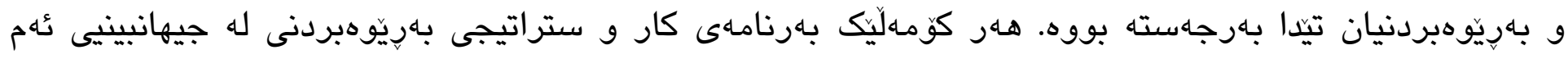

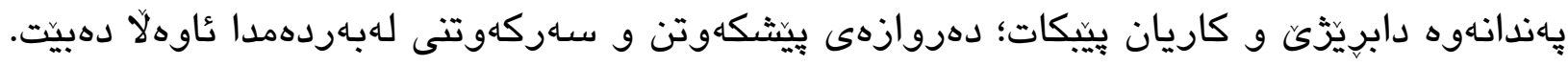

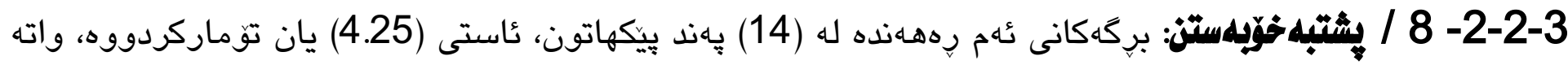

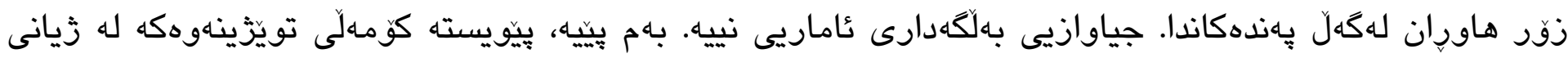

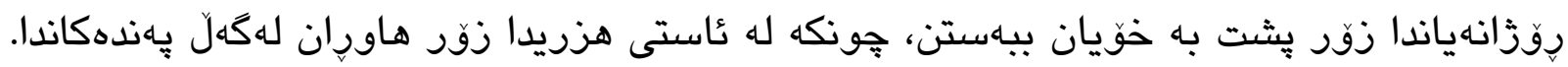

$$
\text { 59. }
$$

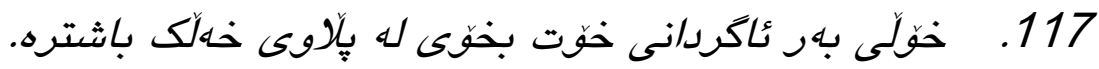

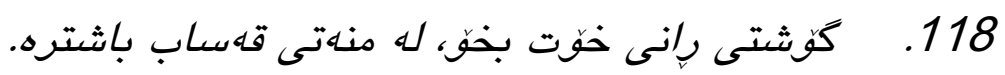

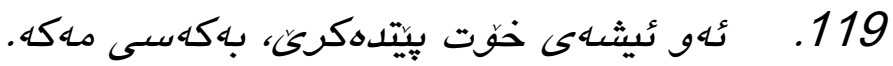

120.

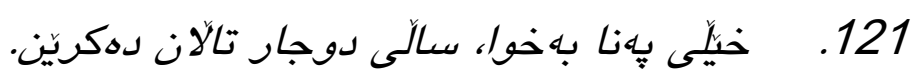

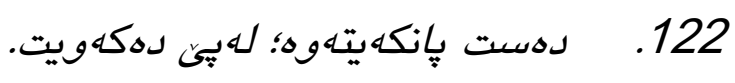

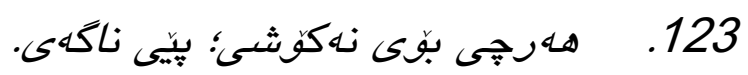




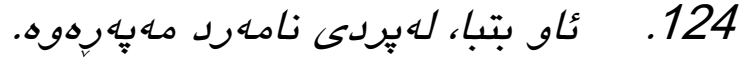

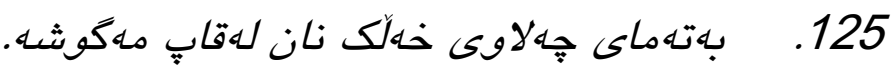

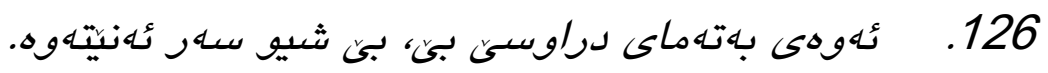

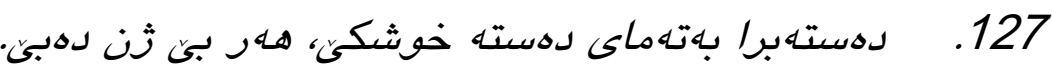

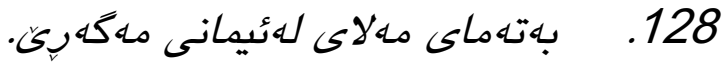

$$
\begin{aligned}
& \text { 129. }
\end{aligned}
$$

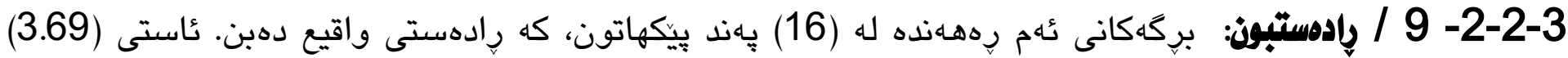

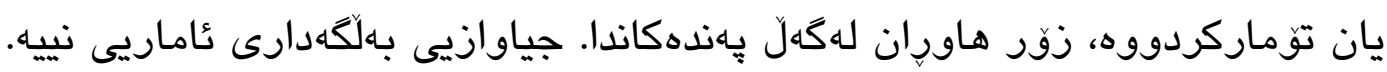

$$
\text { 130. كهويته شارى كويُران؛ دهست به جاوتهوه بكره. }
$$

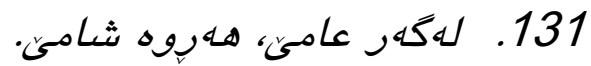

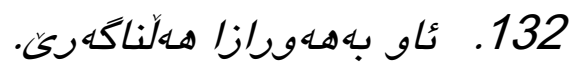

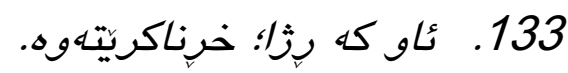

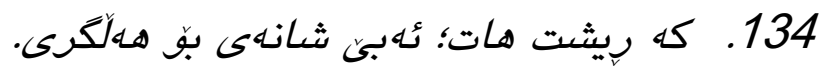

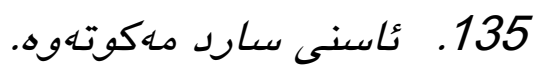

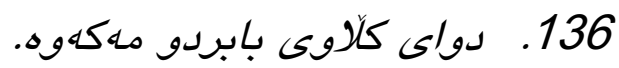

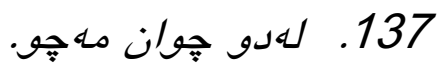

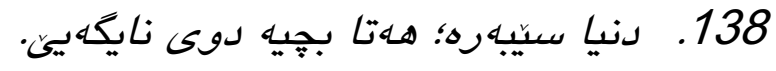

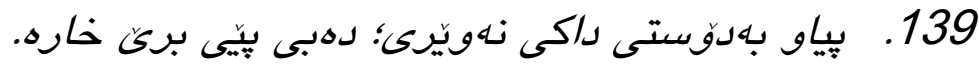

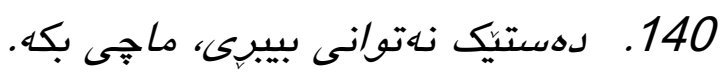

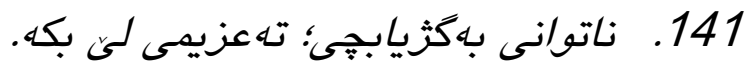

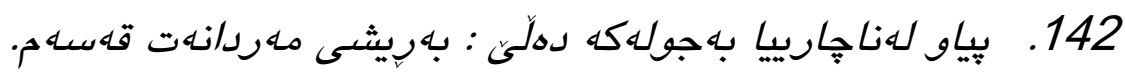

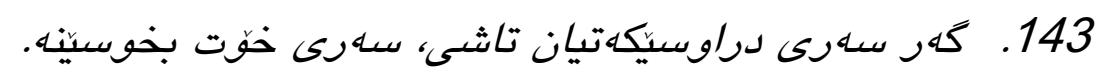

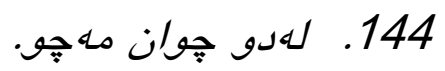

$$
\text { 145. دهستيك نهتوانى بييري؛ ماجيى بكان. }
$$

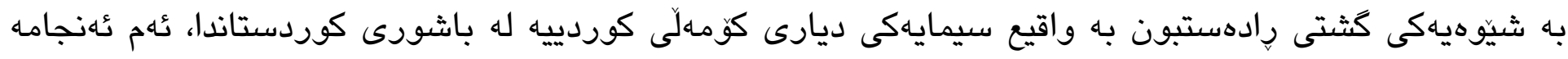

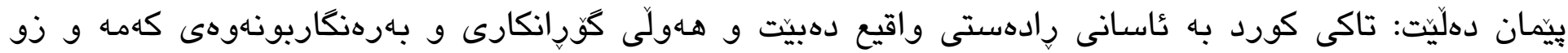

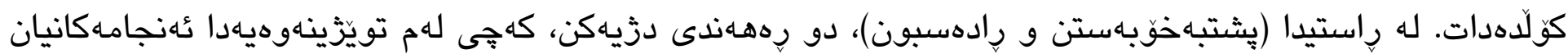

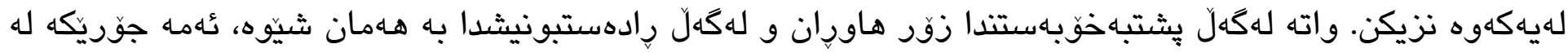

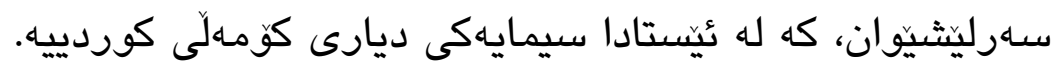

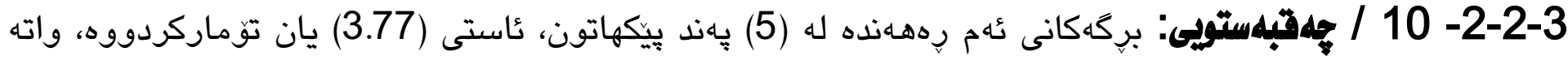

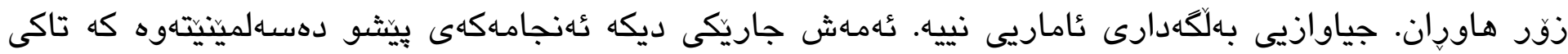

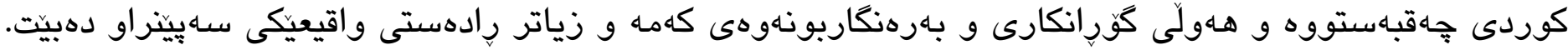




$$
\begin{aligned}
& \text { 146. سواربون عهيبيكي و دابهزين لدو. }
\end{aligned}
$$

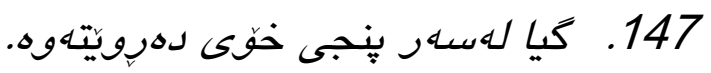

$$
\begin{aligned}
& \text { 148. روى شيرى هـتا بييرى. } \\
& \text { 149. (..... ) به ثيرى تقيه لدكات. }
\end{aligned}
$$

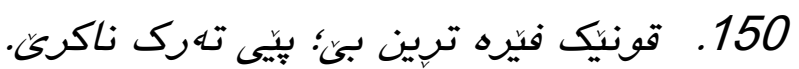

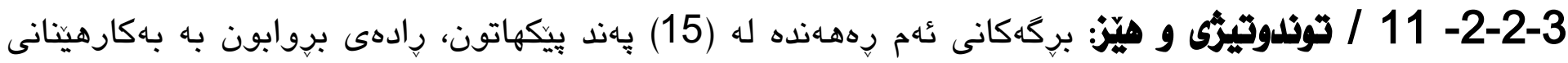

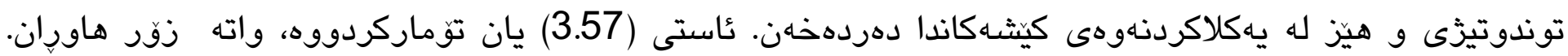

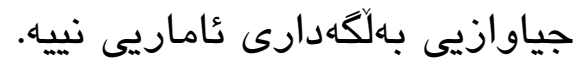

$$
\begin{aligned}
& \text { 151. حهلالخخورى، بيّاهسه لاتييه. } \\
& \text { 152. كوتهك له به هـشتهاهوه هاتووه. }
\end{aligned}
$$

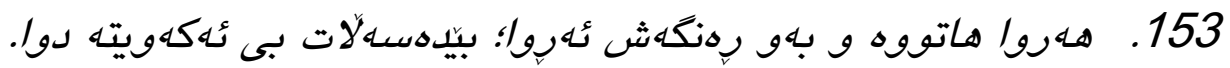

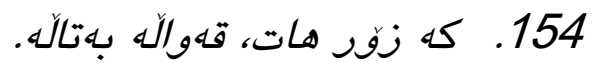

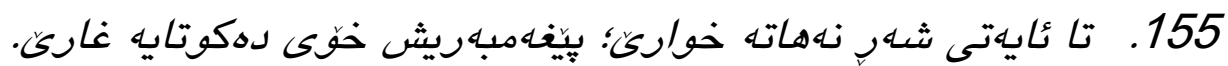

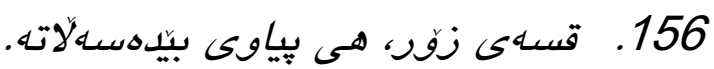

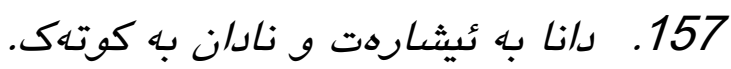

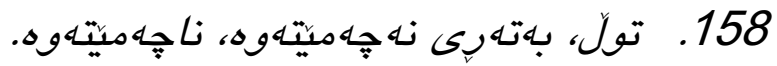

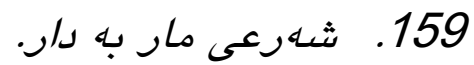

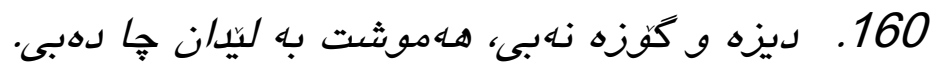

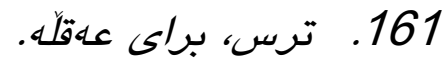

$$
\begin{aligned}
& \text { 162. نهقيزه دهزانيَ كهر به كويّيا لدهروا. }
\end{aligned}
$$

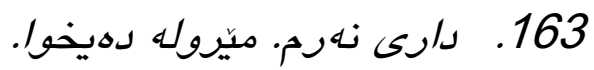

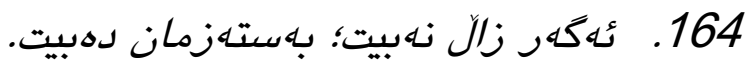

$$
\begin{aligned}
& \text { 80. }
\end{aligned}
$$

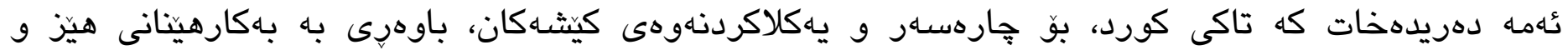

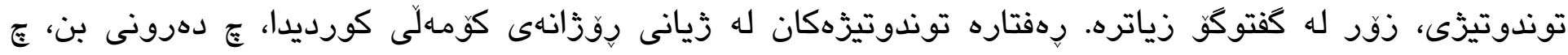

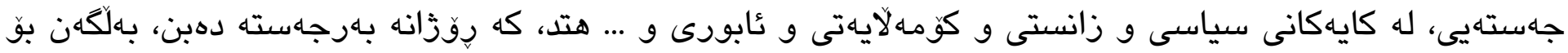
ئهم عئنجامـ.

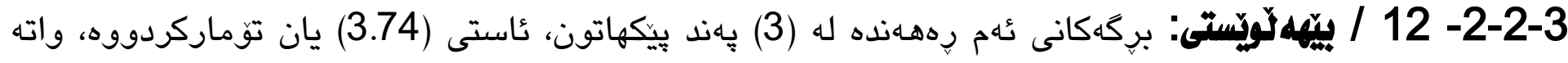
زور هاوران. جياوازيى بهلكَهدارى ناماريى نييه.

165. دهست به كلاوى خوّتهوه بكره؛ با نهييات.

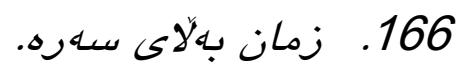

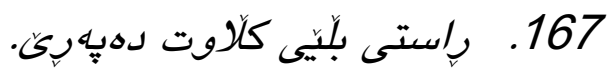




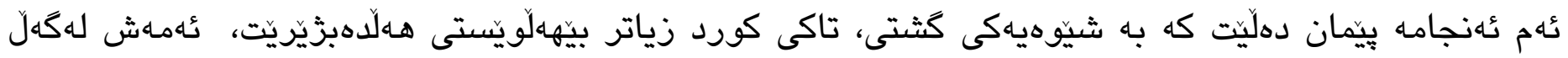

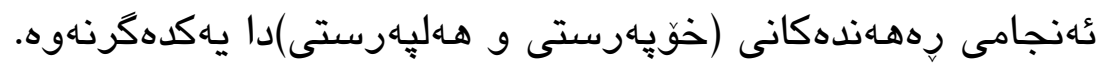

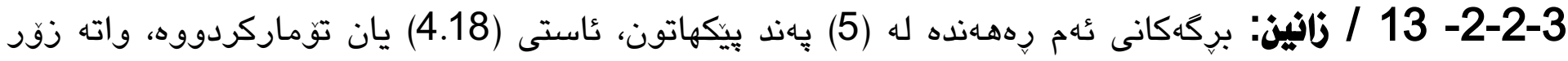

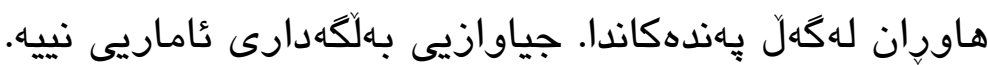

$$
\begin{aligned}
& \text { 168. دوكهل بنى ئاكر نابي. }
\end{aligned}
$$

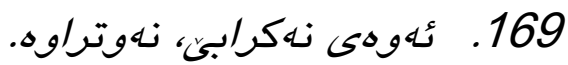

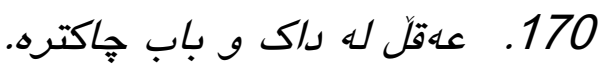

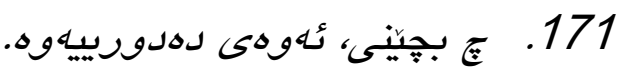

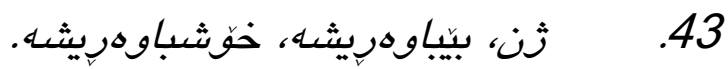

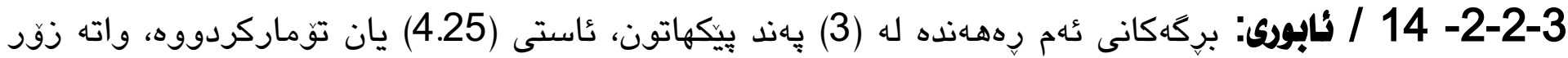

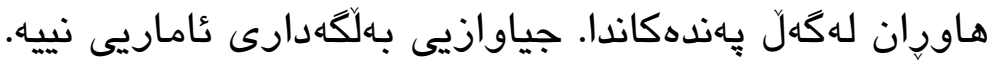

$$
\begin{aligned}
& \text { 172. برامان برايي، كيسهمان جيايي. }
\end{aligned}
$$

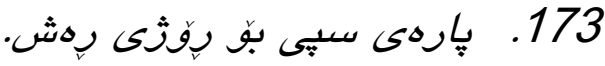

$$
\begin{aligned}
& \text { 174. زهره له نيوهى بكَه ريتيهوه؛ قازانجه. }
\end{aligned}
$$

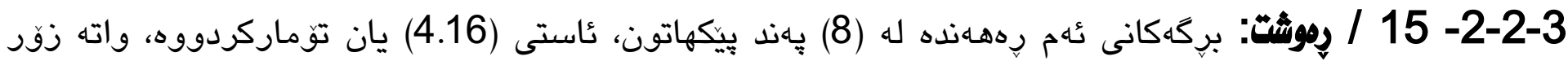

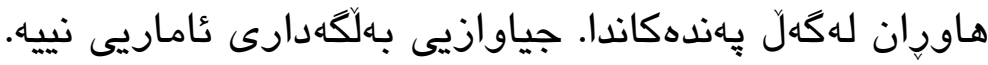

$$
\text { 175. جوانيى خولّق و خو، نهك هى رهنك و ريو. }
$$$$
\text { 176. ئاوت له كانييهك خواردوه، بهردى تئ فرئ مهده. }
$$$$
\text { 177. بياوى باش ئهوديه بهسهر ئارنزووكانيدا زال بيّت. }
$$

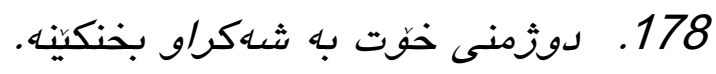

$$
\text { 179. . (... ) به خالَى لدهويّىى. }
$$

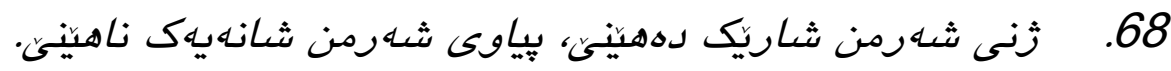

$$
\begin{aligned}
& \text { 115. هـر جاكه، جاكه. } \\
& \text { 116. دراوسيّي جاك، به سهل برا هـيه. }
\end{aligned}
$$

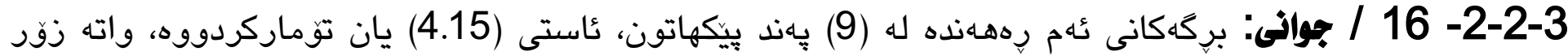

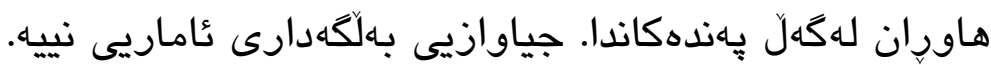

$$
\begin{aligned}
& \text { 180. هـهو شتيك به ليهاتنه. }
\end{aligned}
$$

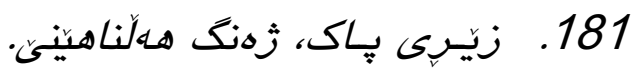




$$
\begin{aligned}
& \text { 182. بياو، نابخى جوانان بشكينيّ. }
\end{aligned}
$$

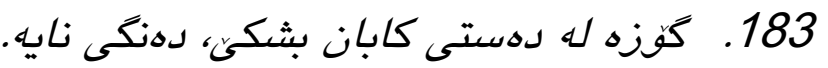

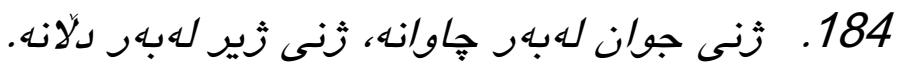

$$
\begin{aligned}
& \text { 185. مزكهنت بروخئ ميحرابى هـر دهمينين. }
\end{aligned}
$$

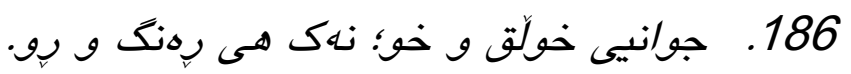

$$
\begin{aligned}
& \text { 187. كندوره به ردونكى نييه. }
\end{aligned}
$$

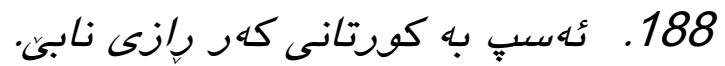

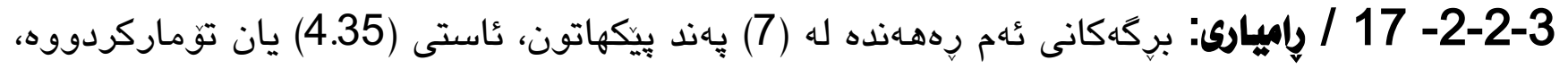

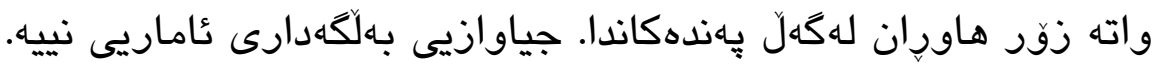

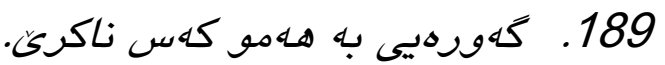

$$
\begin{aligned}
& \text { 190. 189. يَّى زولّم كورته. }
\end{aligned}
$$

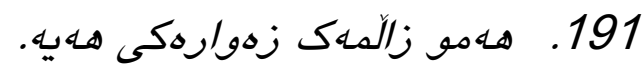

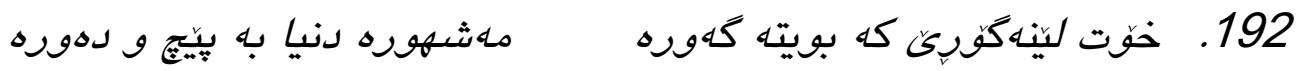

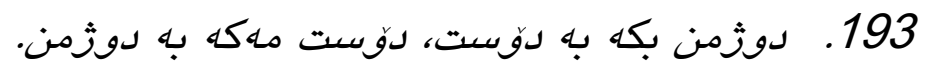

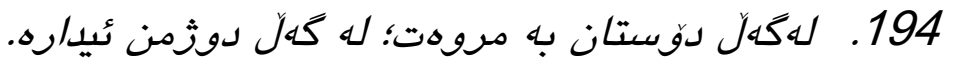

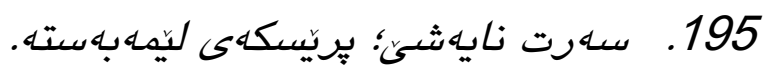

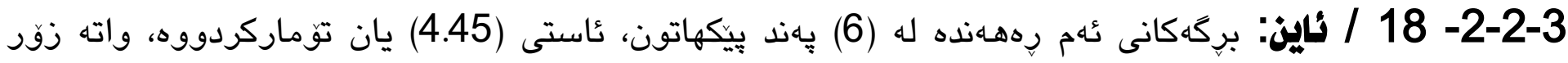

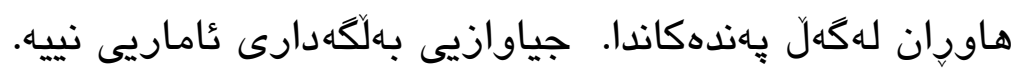

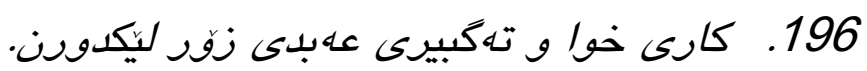

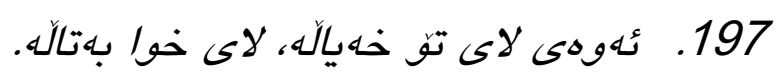

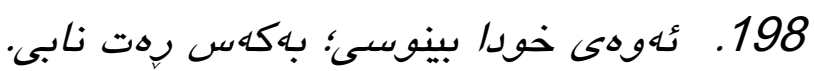

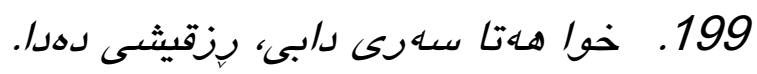

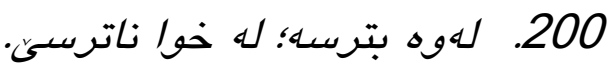

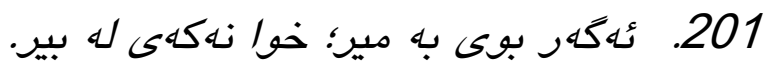

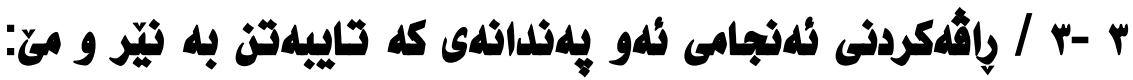

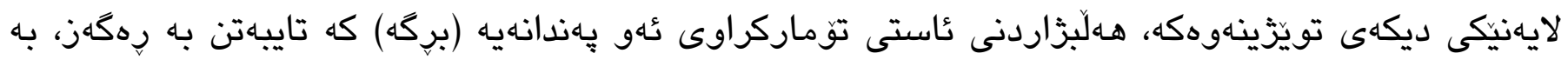

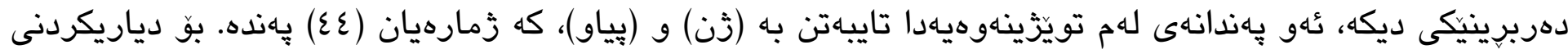

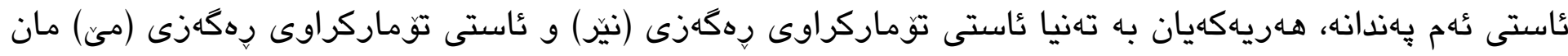

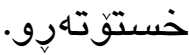

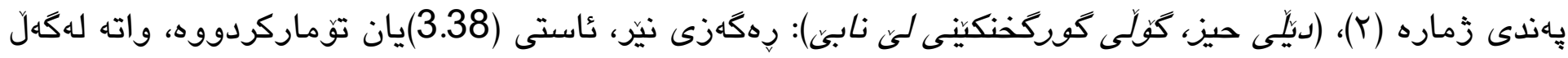

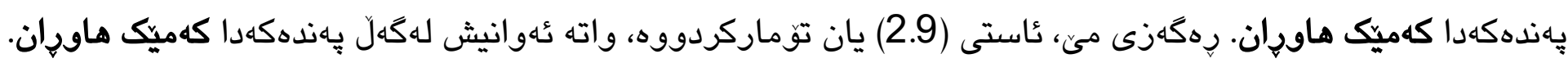




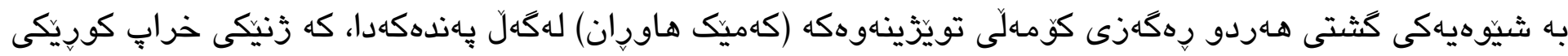

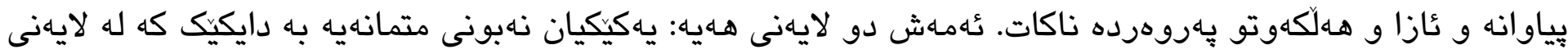

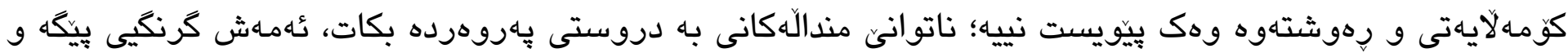

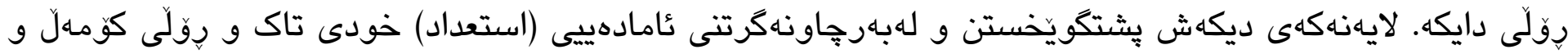
دهوروبهره له يهروهردهدا.

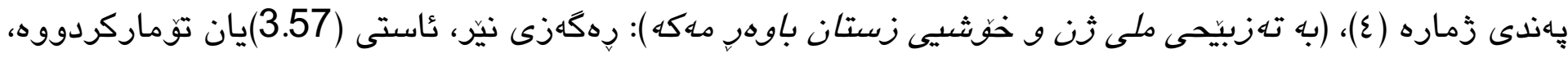

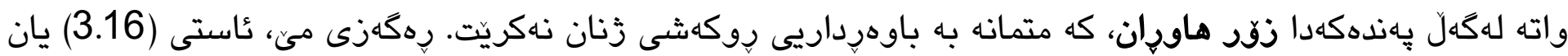

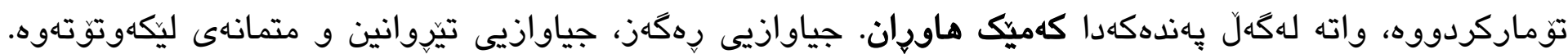

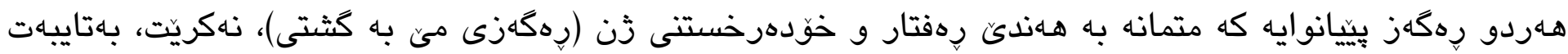

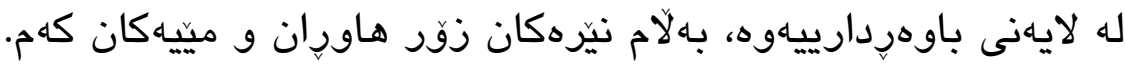

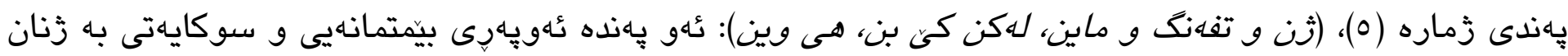

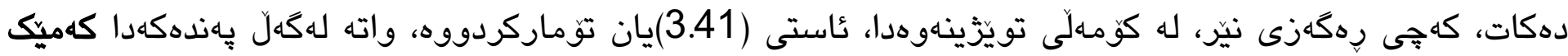

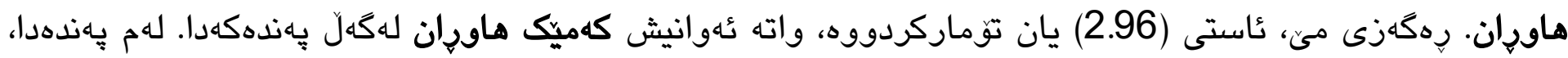

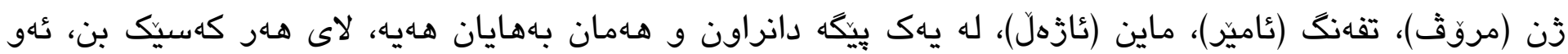

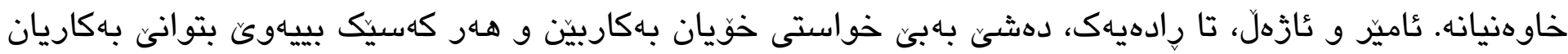

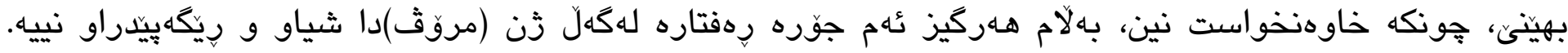

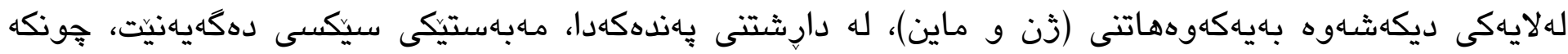

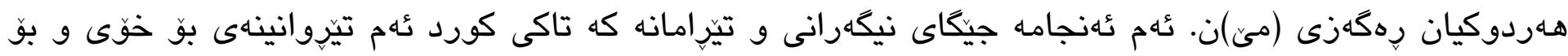

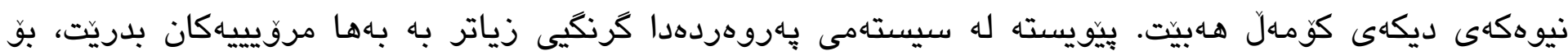

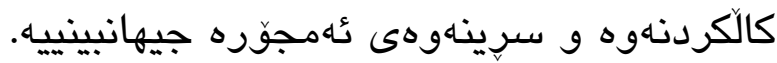

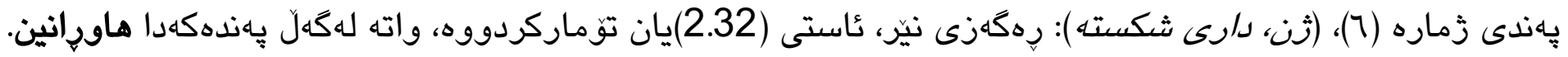

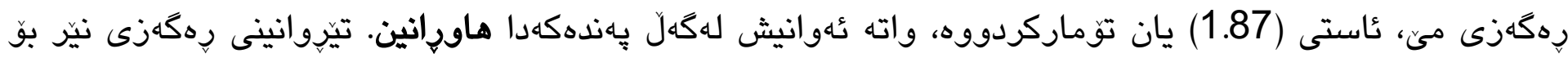
خن، تُهرينييه.

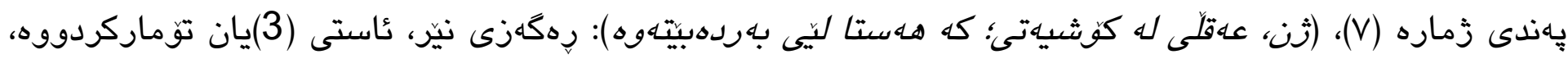

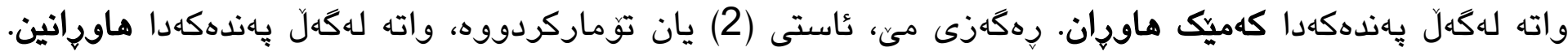

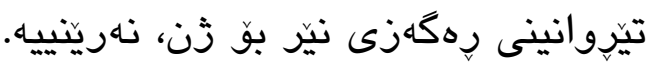

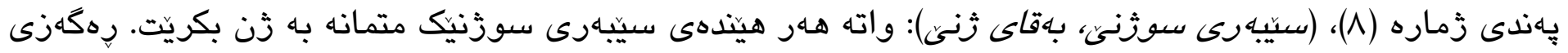

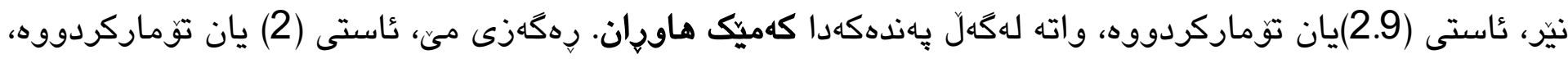

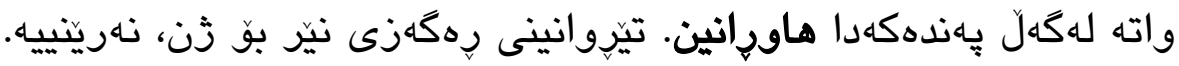




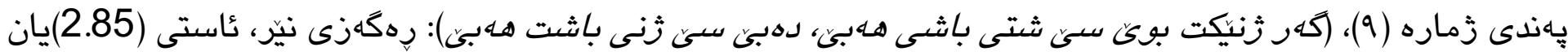

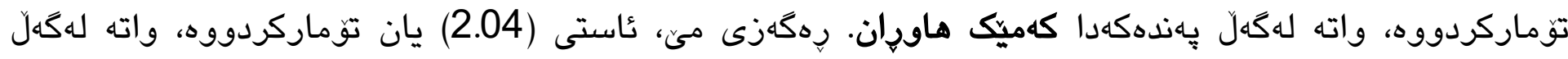

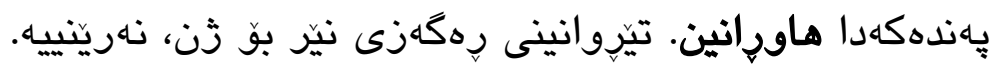

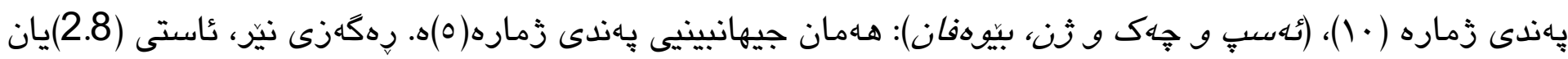

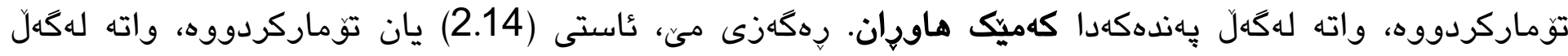

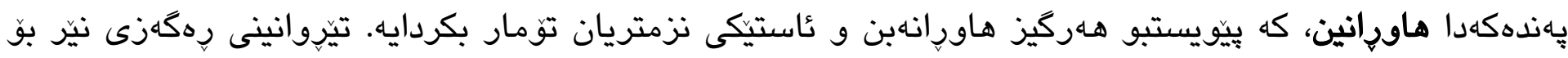

خنن، نارينييه.

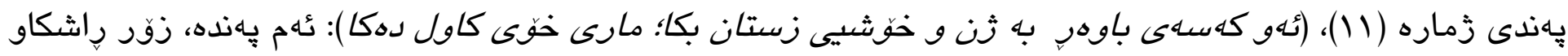

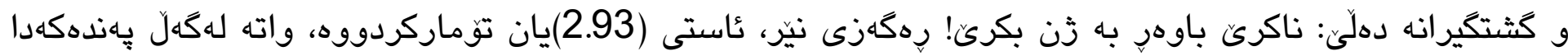

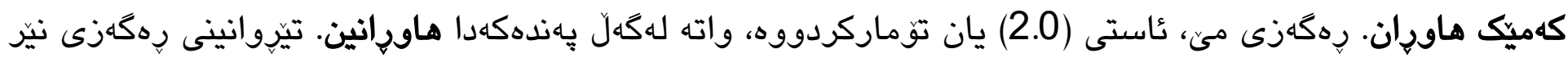
بو ثنن، نهريتييه.

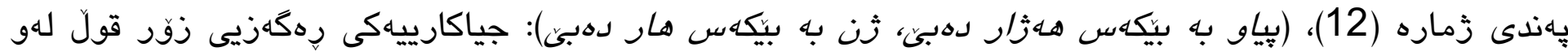

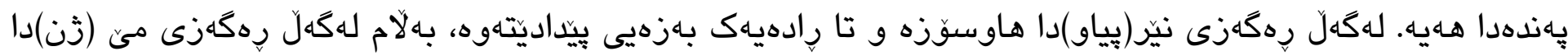

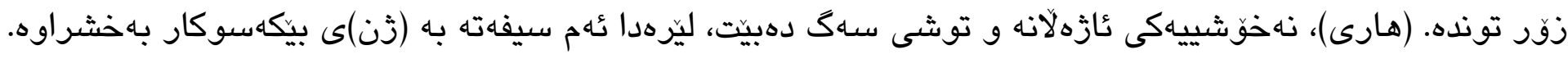

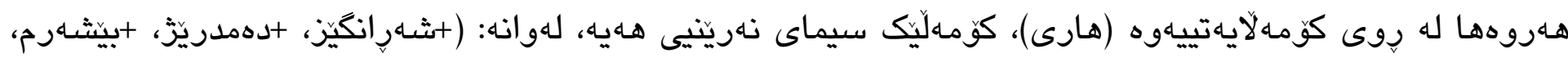

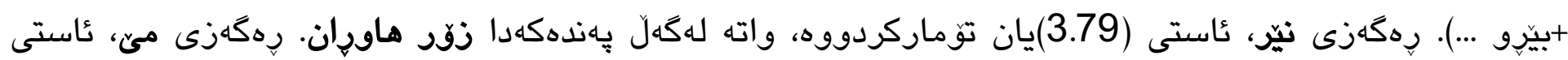

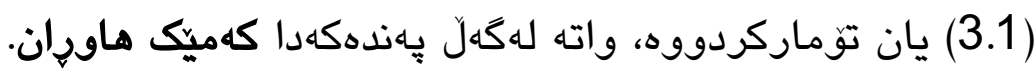

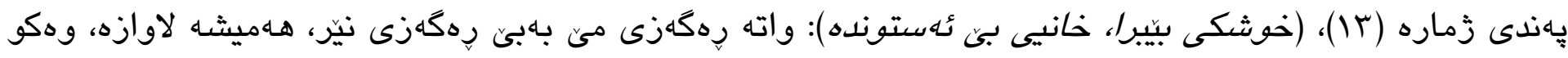

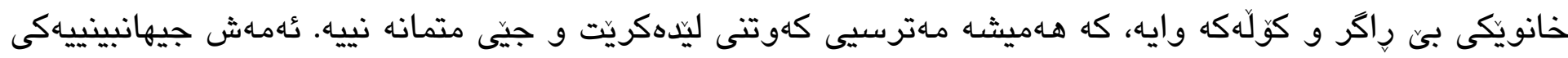

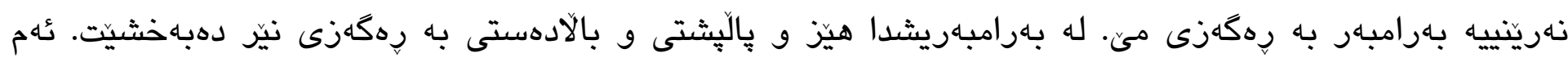

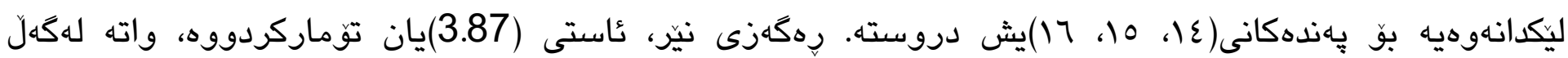

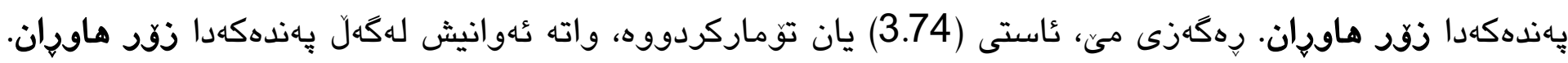

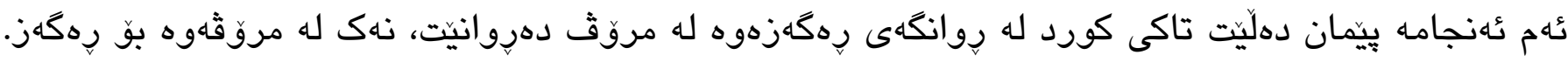

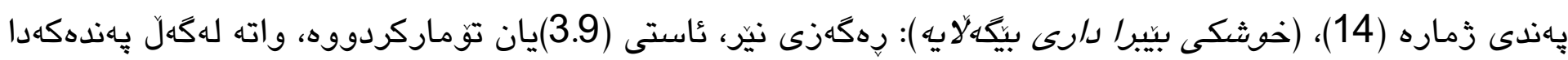

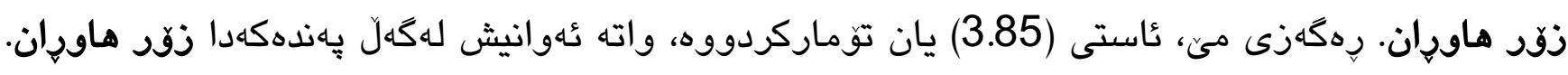

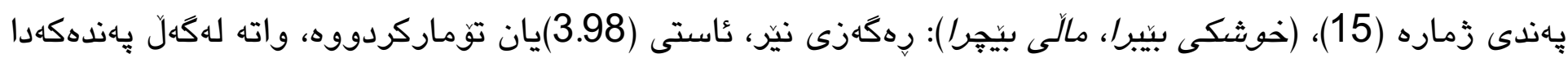

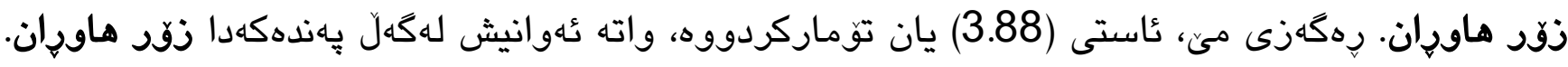

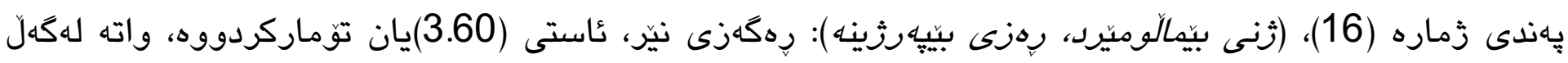

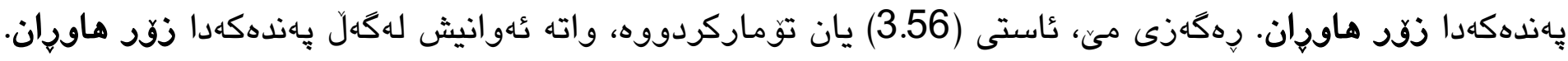




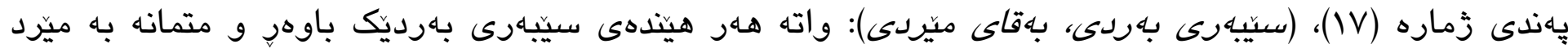

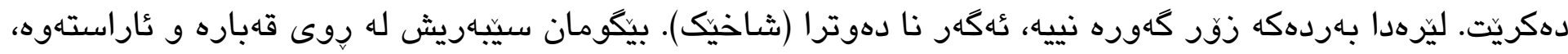

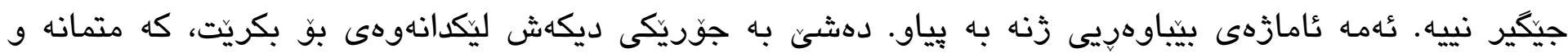

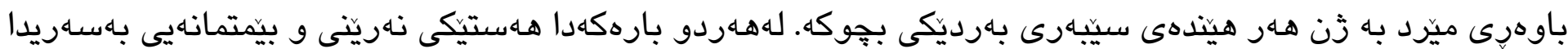

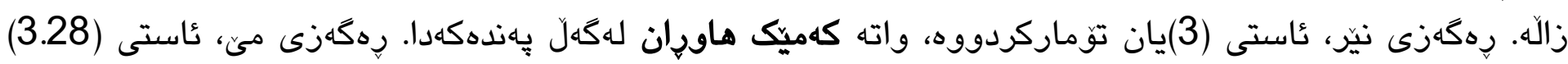

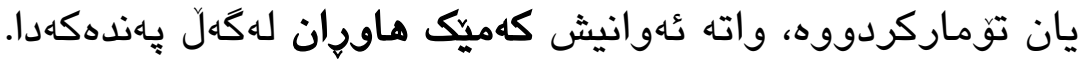

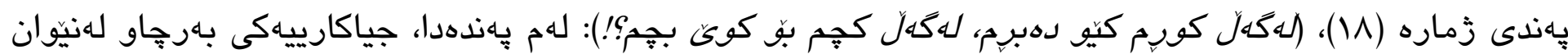

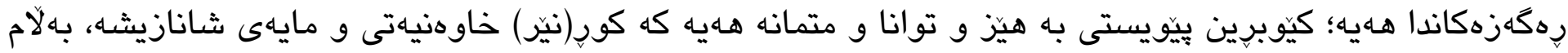

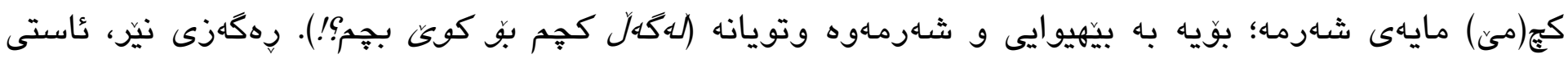

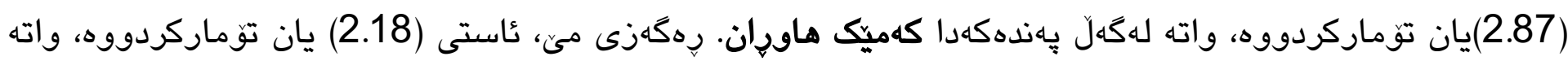

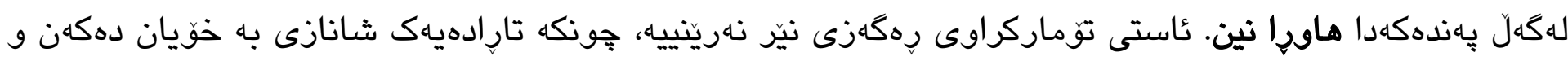

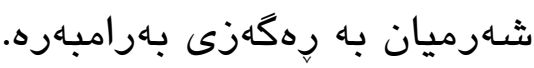

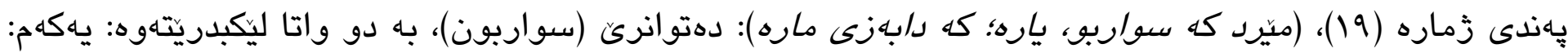

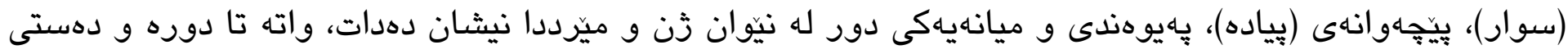

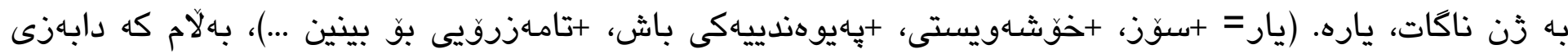

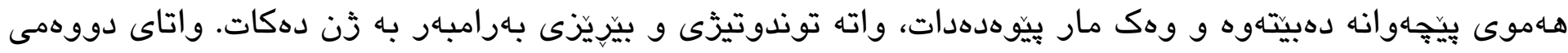

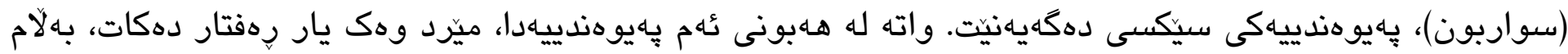

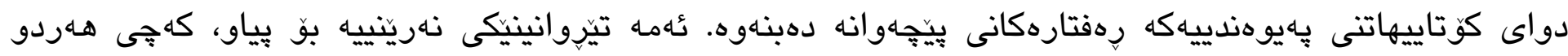

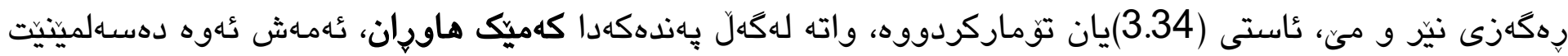

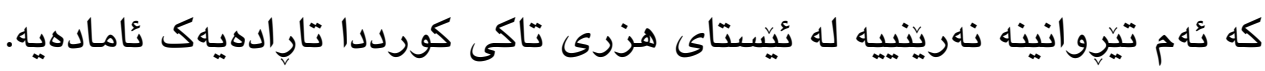

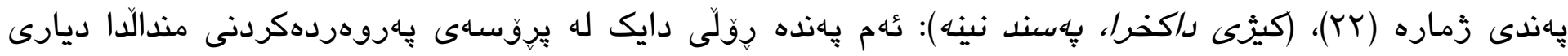

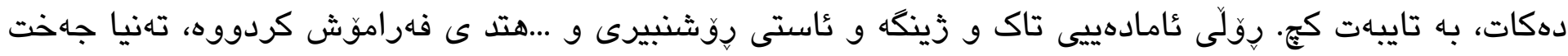

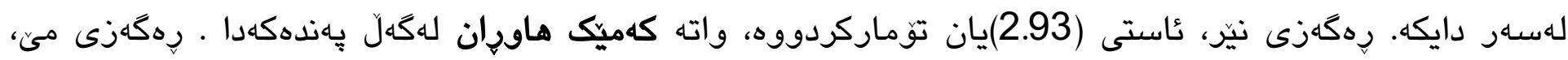

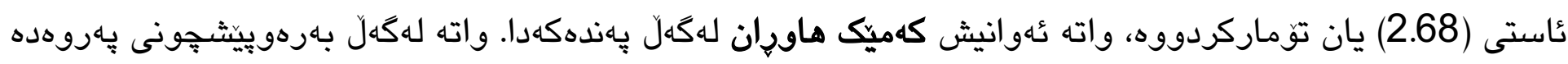

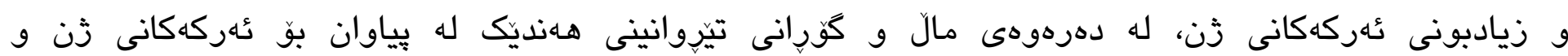

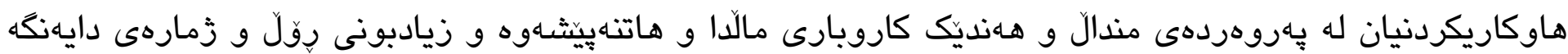

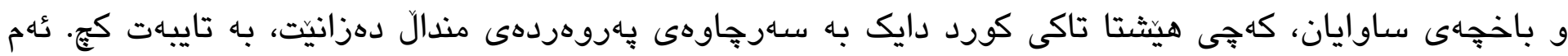

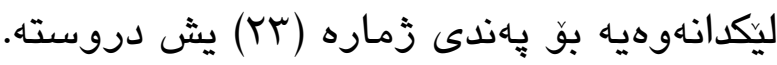

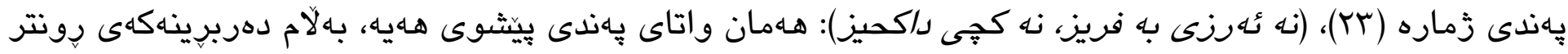

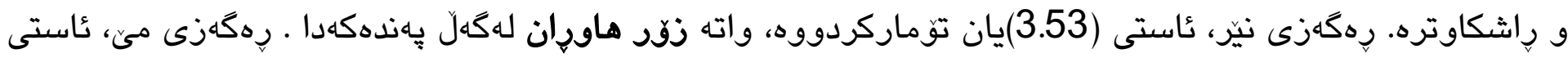

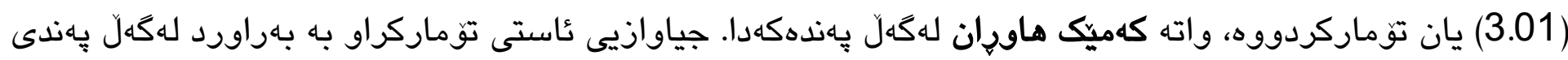

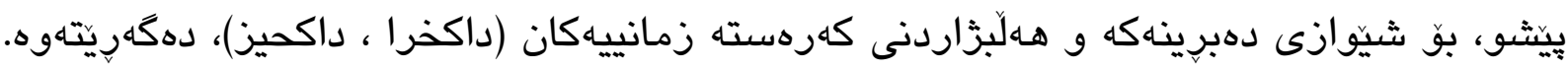




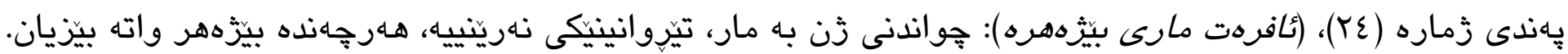

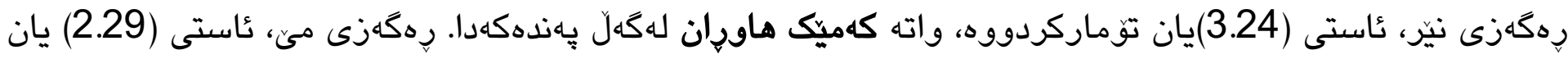

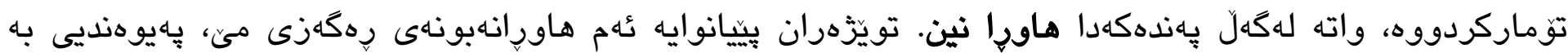

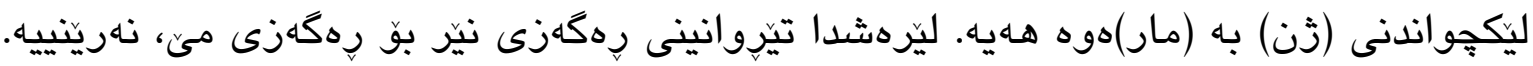

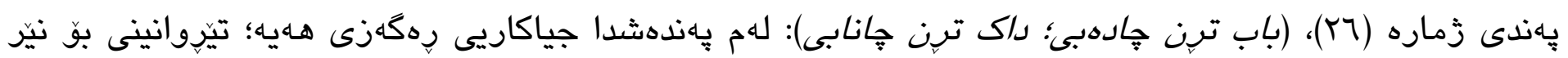

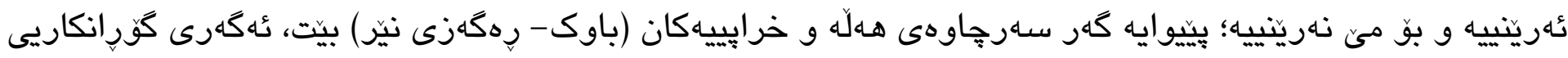

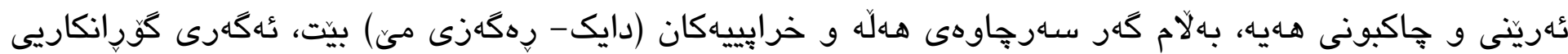

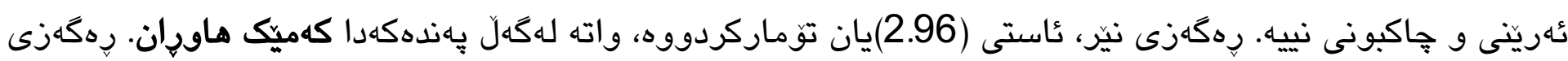

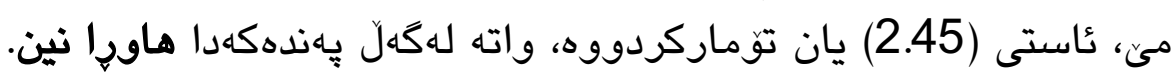

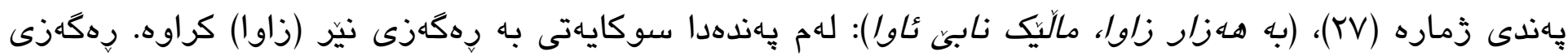

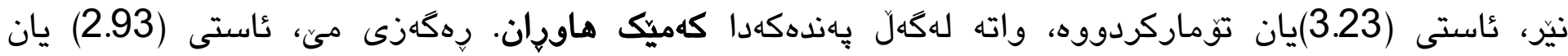

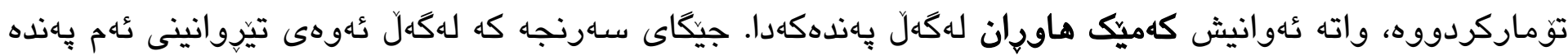

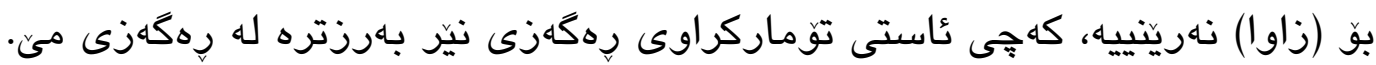

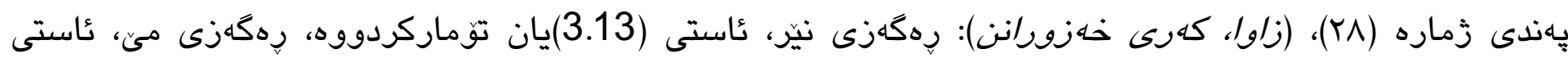

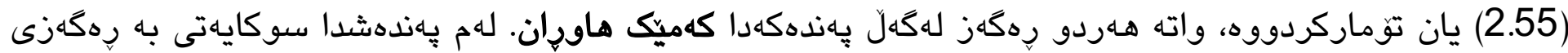

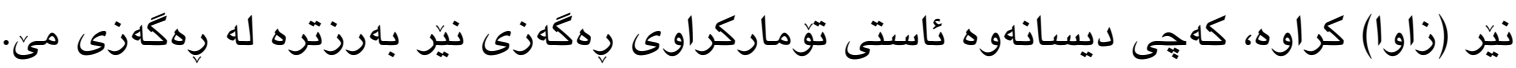

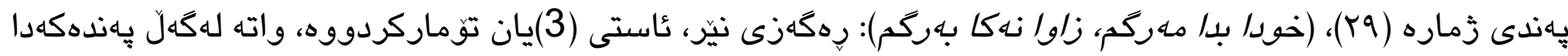

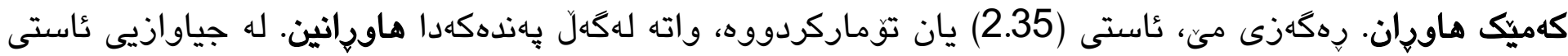

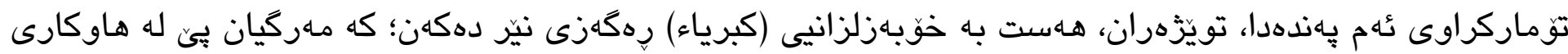
و دهستى يارمهتيى زاوا باشترها

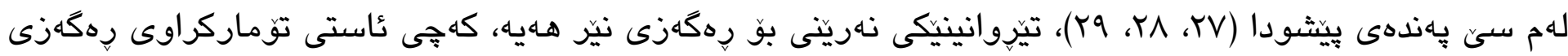

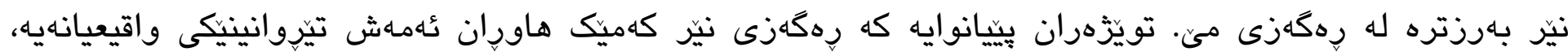

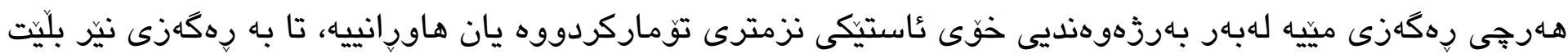
من بامشيّوهيات نابينم.

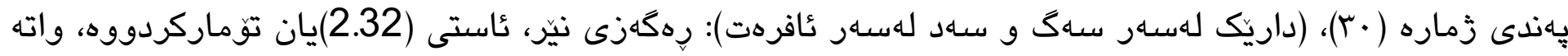

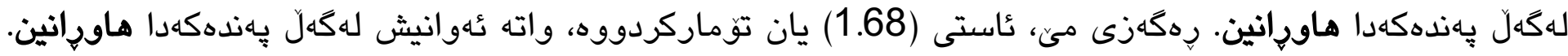

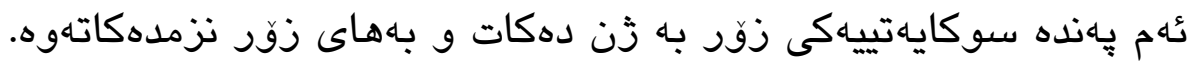

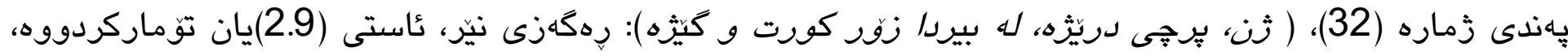

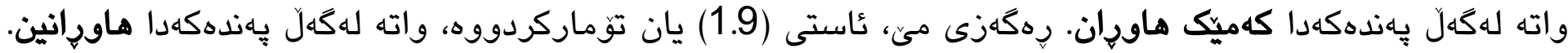




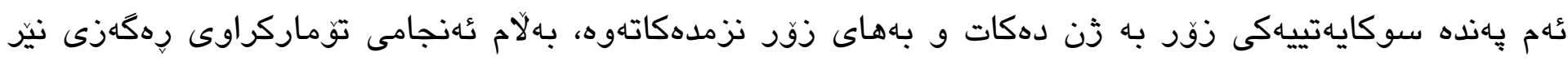
ناهينييه.

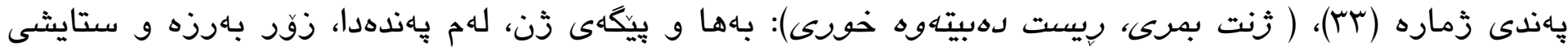

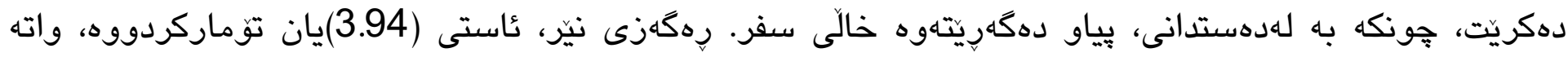

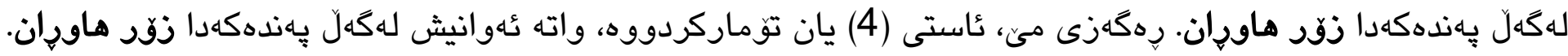

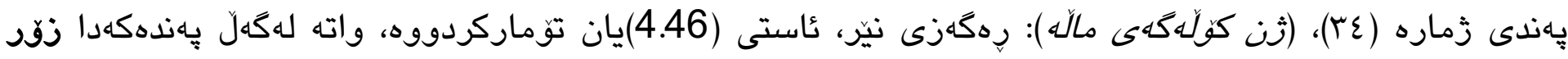

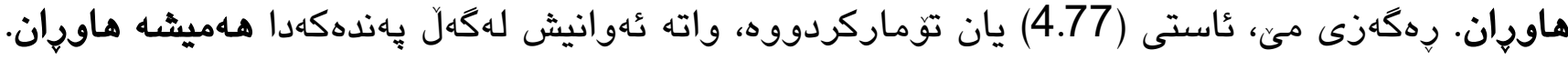

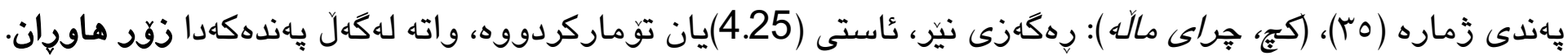

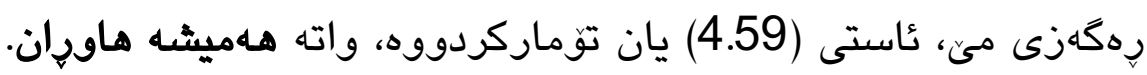

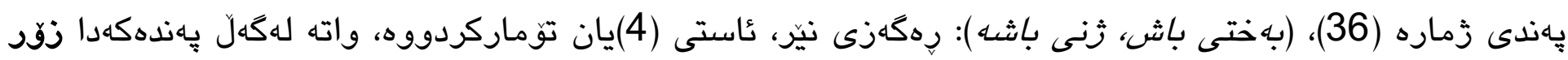

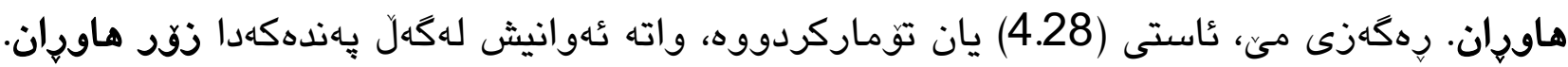

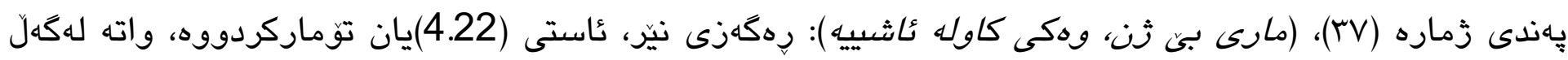

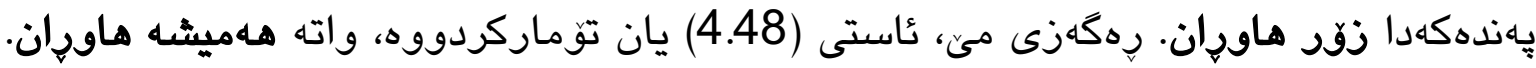

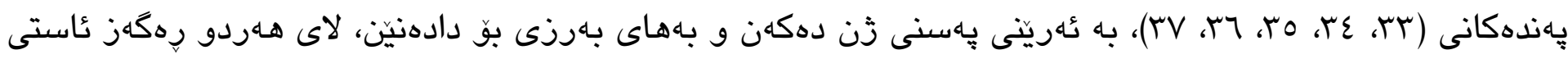

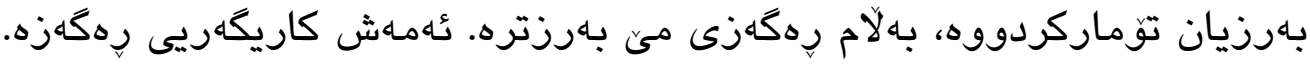

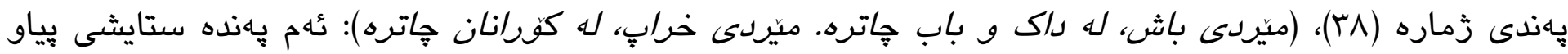

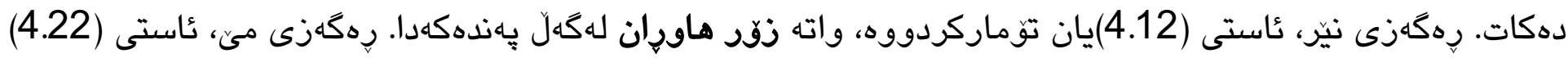

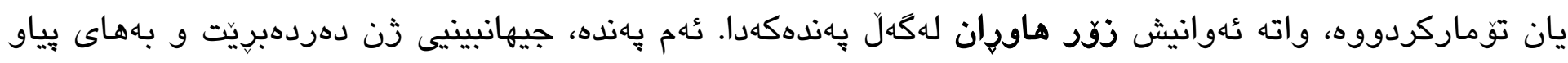

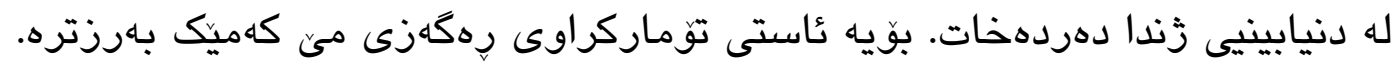

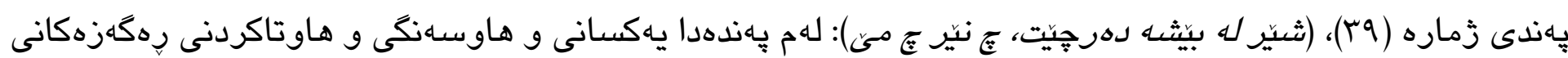

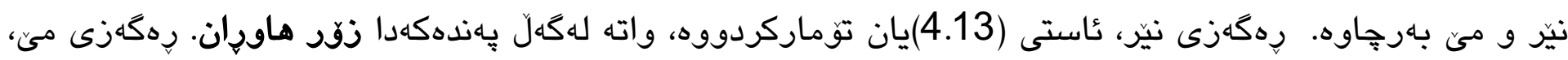

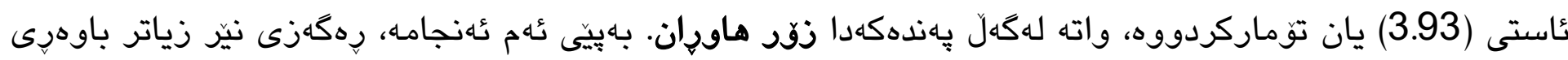

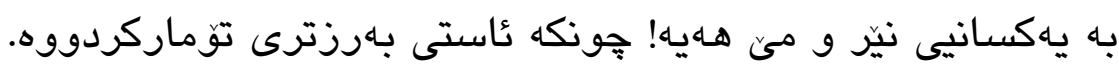

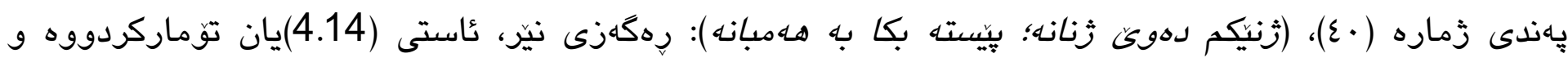

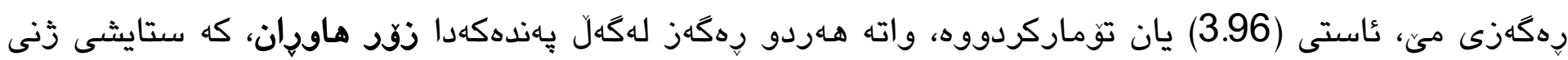
بـهيَز و بـهتوانا دهكات.

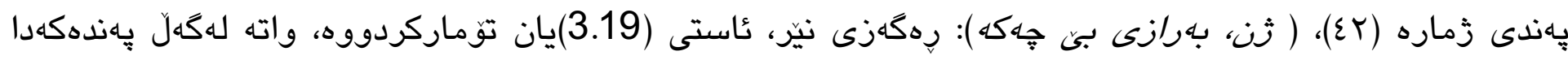

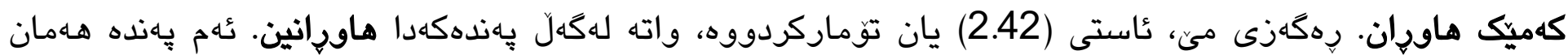

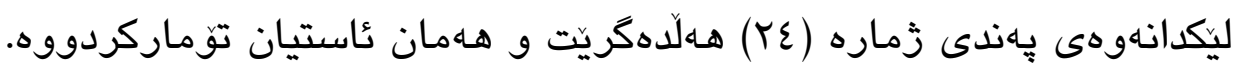




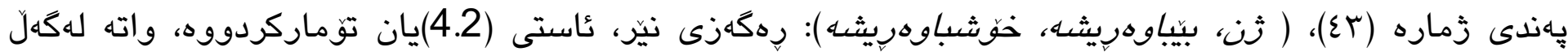

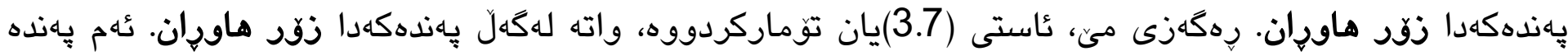

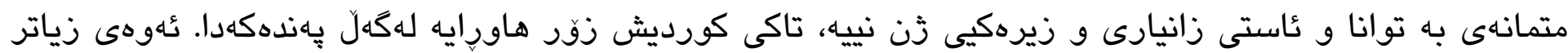

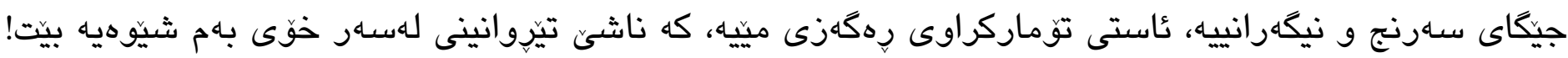

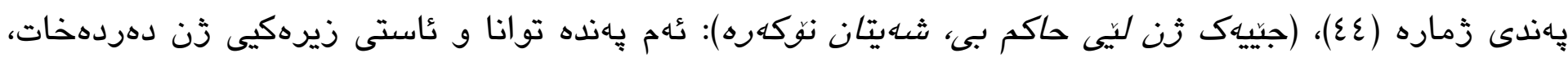

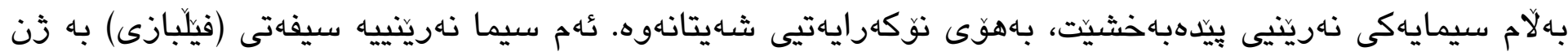

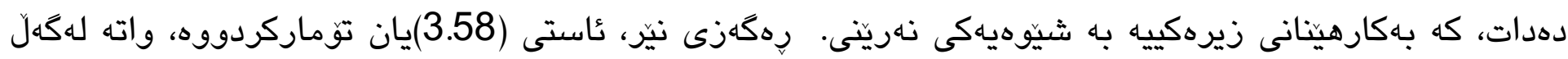

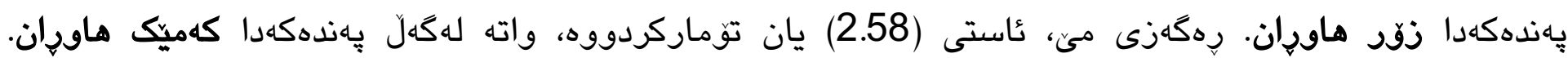

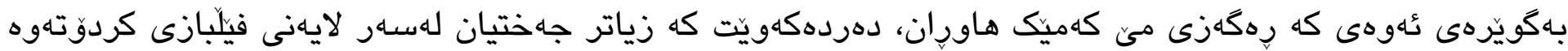
نهك زيرهكى و تواناى ثن.

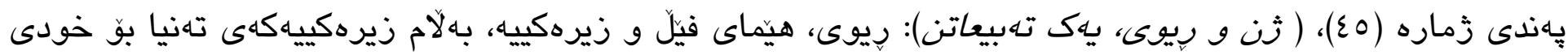

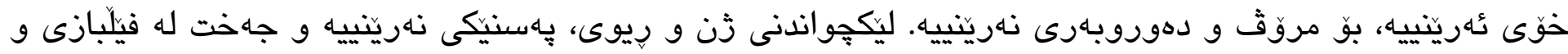

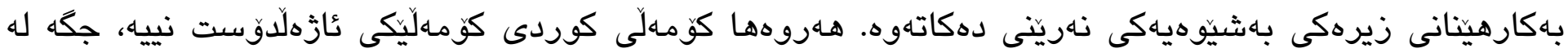

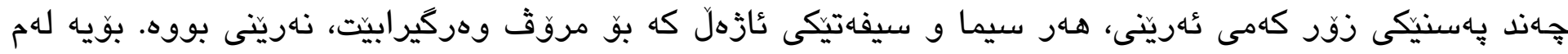

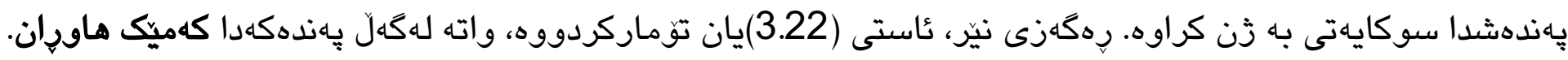

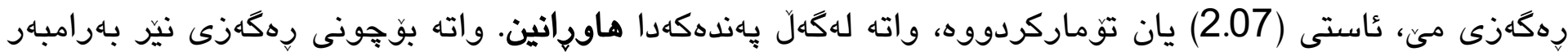

به زن، نهارينييه.

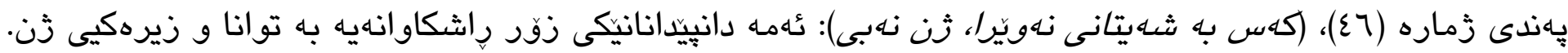

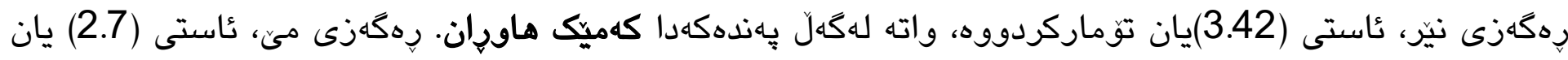

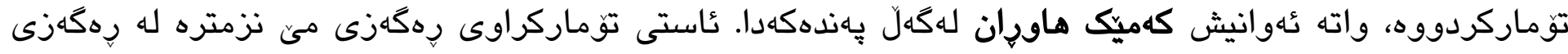

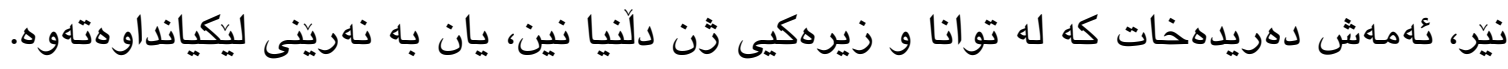

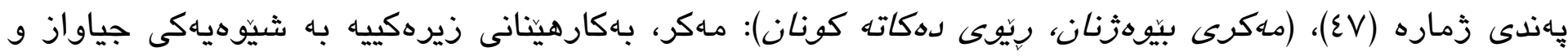

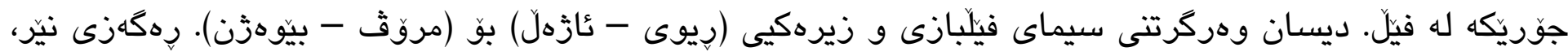

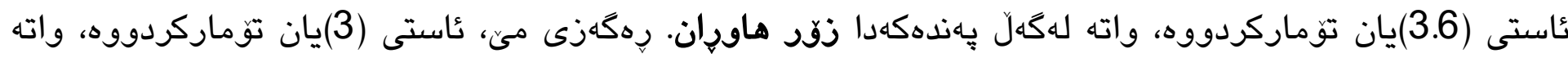

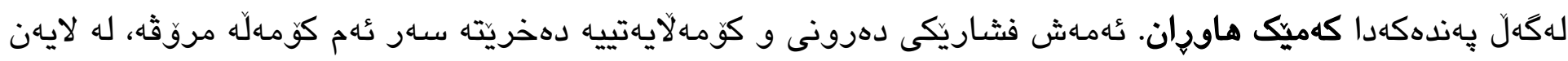
تاكى كومهالّى كوردييهوه.

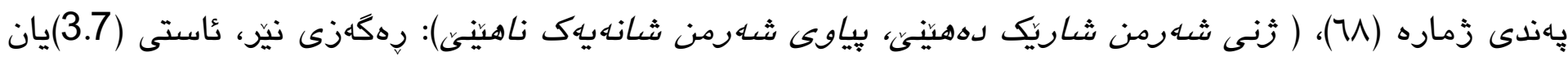

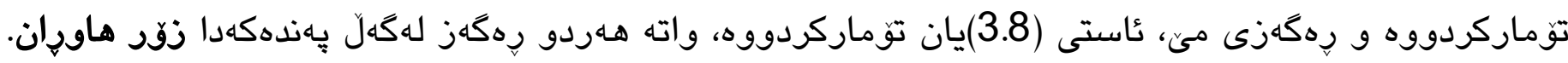

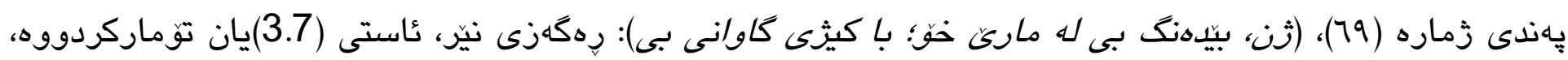

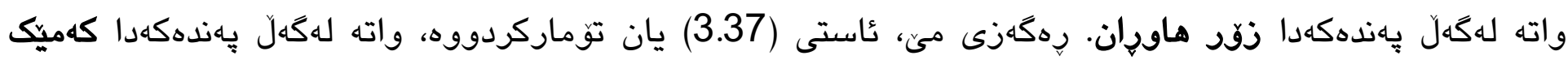




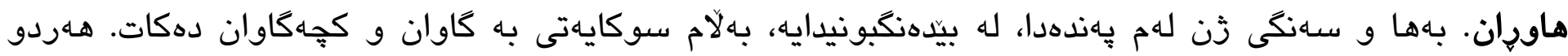

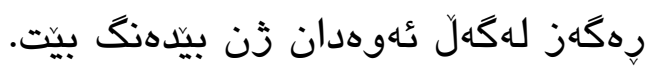

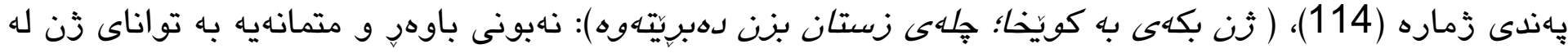

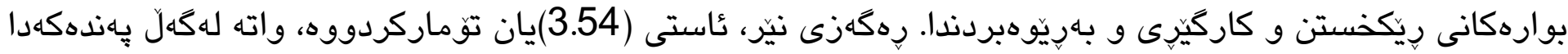

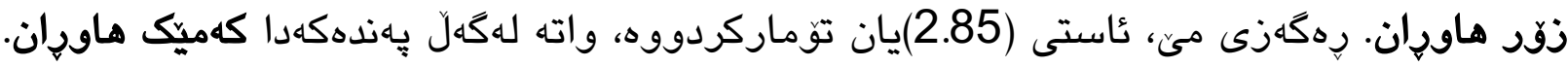

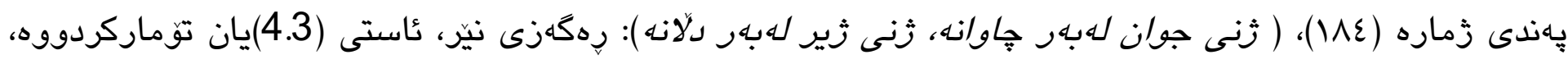

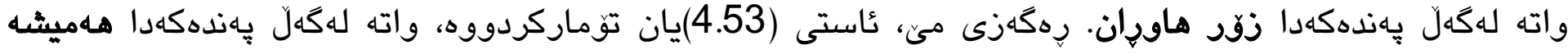
هاوران.

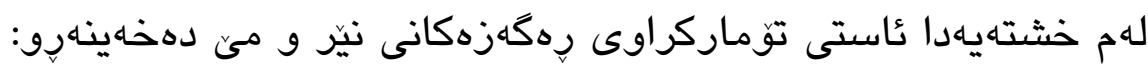
خشتهى زثماره (6)

جياوازيى رِكَّز للهو يلهندانهى تايبهتن به رِكَهزكانى نيّر و ميّ

\begin{tabular}{|c|c|c|c|c|c|c|}
\hline سـارجهام & هاورام & هُود & كامينك & هاور انيم & هاورِانيز & رهذكَز \\
\hline 44 & 1 & 21 & 20 & 2 & 0 & نيّر \\
\hline 44 & 4 & 11 & 16 & 13 & 0 & ميّى \\
\hline
\end{tabular}

خشتهى زماره (V)

نُاستى تُوماركراوى هلهردو رِكَّزى نيّر و ميّ

\begin{tabular}{|c|c|c|}
\hline مئى عاستى رهكهزى & نَّاستى رِكَهزى & 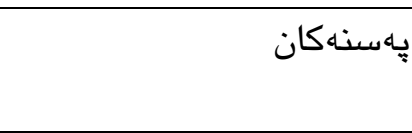 \\
\hline 3.45 & 3.68 & يِهنى ئهرينيى رِكَهزى نيّر \\
\hline 2.97 & 3.23 & يهاسنى نهرينييى رِكَهزى نيّر \\
\hline 4.16 & 4 & 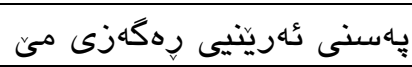 \\
\hline 2.68 & 3.26 & يهاسنى نهرينيى رِكَهزى مئ \\
\hline
\end{tabular}

له شيكردنهوهيهكى ديكهى تُهنجامى توماركراوى عُهم (ع ع) پِهندهى سهرهوه، (خشتهى V )، دهردهكهويّت كه جياوازيى

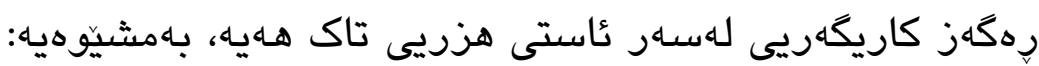

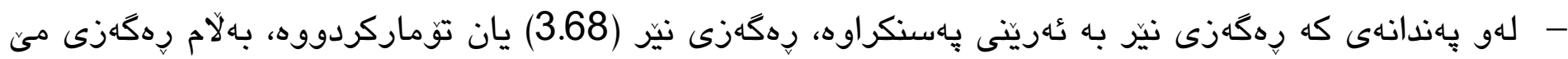

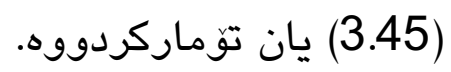




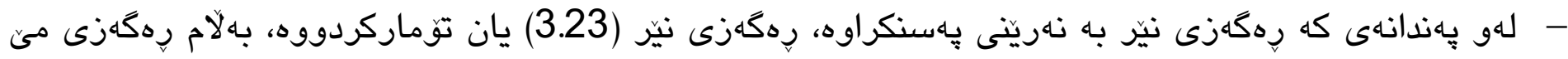

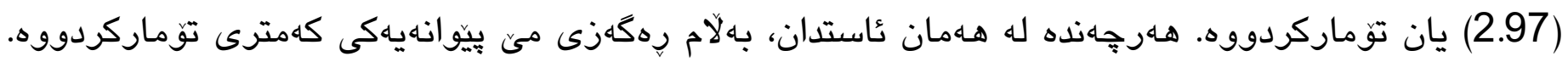

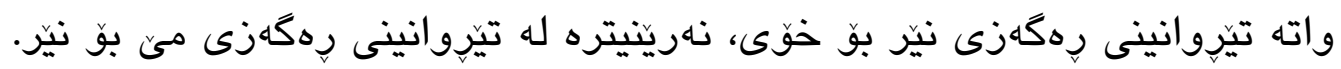

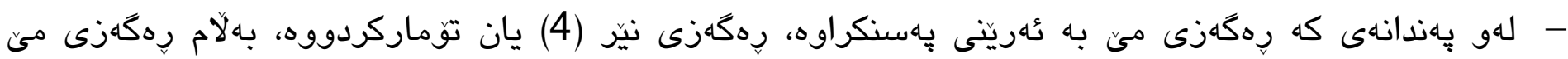

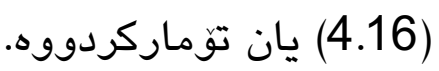

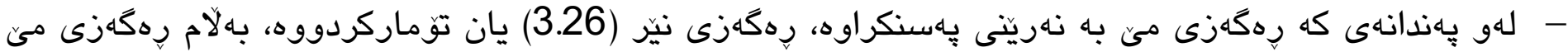
(2.68) يان توماركردووده. -

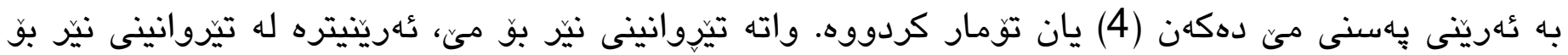
خَّى.

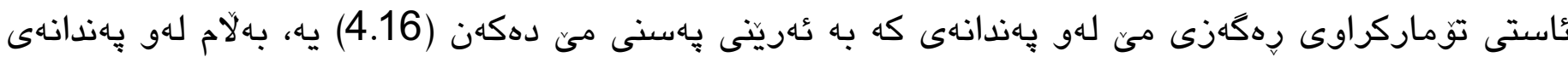

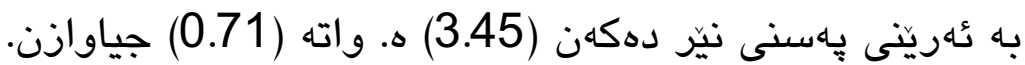

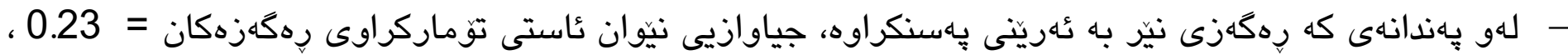

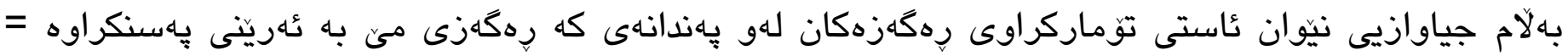
. 0.16

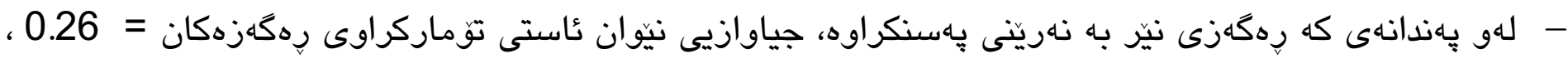

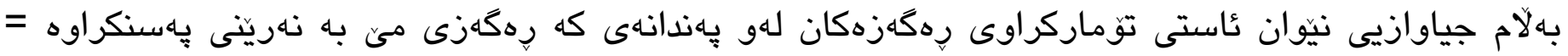
0.58

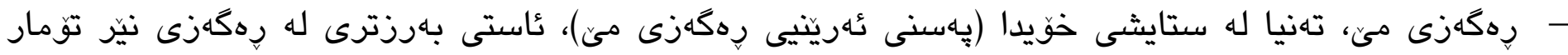
كردووه، له هـرسيّ بارهكهى ديكهدا ئاستى نزمترى تُومار كردووها

\section{: Conclusion}

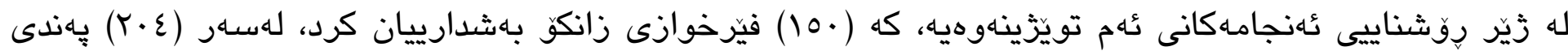

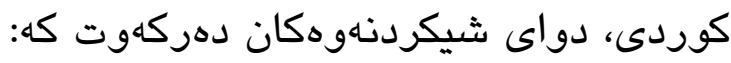

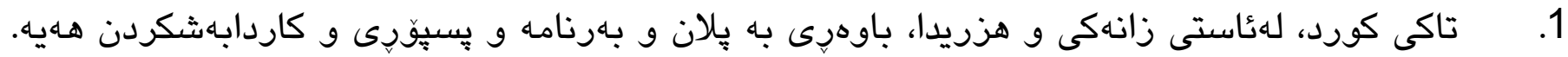
2.

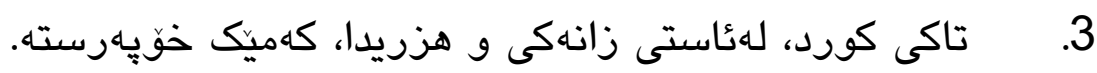

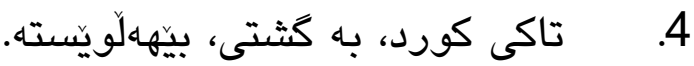
5. 6.

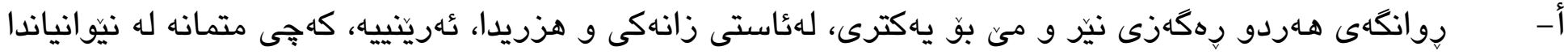
زوّر كهمه. لهأستى زانهكى و هزريدا، زوّر يشت بهخوّى دهبهستيت، كهجى زو رِادست دهبيت. 


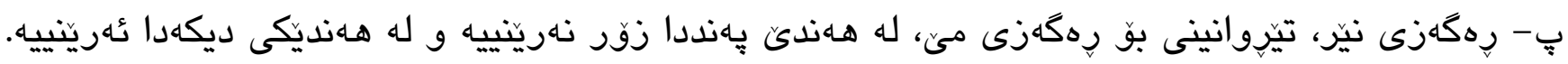

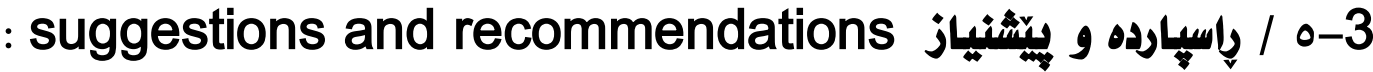

تويّزهران يِيشنياز دهكهن كه له سيستهمى يـروهردهدا:

1. كرنكييهكى زوّر زياتر به بههاى مروّيى بلريّت و له هـر بوار و بابهتيكى كونجاودا جهختيان لهسهر بكريت،

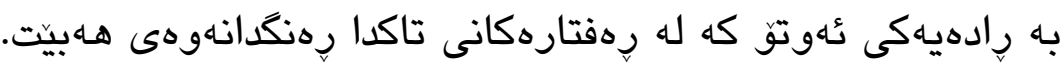
2.

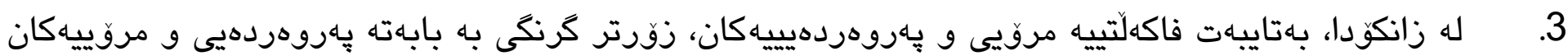

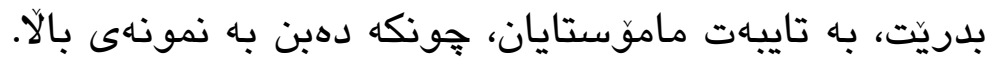

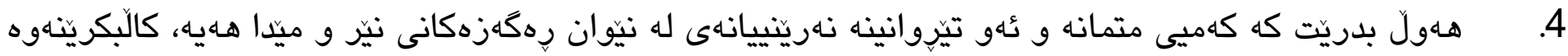
و بهردو نهمان بيريّن.

5.

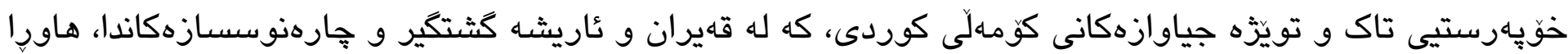
و هاوهـلْويَست نين. 


\title{
The Effects of Gender Differences in the Kurdish Individual's Vision of Human Values in Kurdish Proverbs and its Dimensions Among University Students - A Cognitive Study-
}

\section{Hemin Abdulhameed Shams}

Kurdish Language Department, Faculty of Education, Koya University, Koya, Kurdistan Region, Iraq.

E-mail: hemin.shams@koyauniversity.org

\author{
Khalid Ismail Mustafa \\ Education \& Psychology Department, Faculty of Education, Koya University, Koya, Kurdistan \\ Region, Iraq.
}

E-mail: khalid.ismail@koyauniversity.org

\begin{abstract}
:
The research has a variety of aims. First, to clarify the cognitive level of the Kurdish individual about human values in Kurdish proverbs and its related dimensions, as well as to know the impact of gender differences on Kurdish proverbs and its dimensions. To achieve these two aims, 150 undergraduate university students participated randomly in the current research. The researchers used a self-designed data-gathering tool consisting of 204 varieties of Kurdish proverbs, each proverb with five Likert options. The psychometric of collection tool which is the validity and reliability of the instrument was measured and was at the required level and good enough to be used. In order to analyze the data of the research, the researchers used the (SPSS) statistical package for the social sciences program. After analyzing the data, the results of the research showed that the cognitive level of the Kurdish individual about human values was at a high and positive level according to the five Likert options, and the effect of gender differences on human values and their dimensions were not statistically significant except for four dimensions. The analysis also showed controversial results for negative proverbs about each gender variable. In conclusion, the study in light of the research results made some recommendations and scientific suggestions to the related field.
\end{abstract}

Keywords: Proverb, Human Value, Gender, Cognitive Level, Semantic Dimension. 


\section{سلوجهاومكان}

ابوجادو، صالح محمد على، ع..r. سيكولوجية التنشئة الاجتماعية. ع المحرر عمان - الاردن: دار المسيرة للنشر و التوزيع و الطباعة. الزعبي، احمد محمد، 2010. علم النفس الاجتماعي. عمان: دار زهران.

العصيلي، عبدالعزيز بن ابراهيم، 2006. علم اللغة النفسي. مكان غير معروف:جامعة الامام محمد بن سعود الاسلامية. النورى، قيس، 1981. الحضارة و الشخصية. بغداد: دار الكتب للطباعة و النشر.

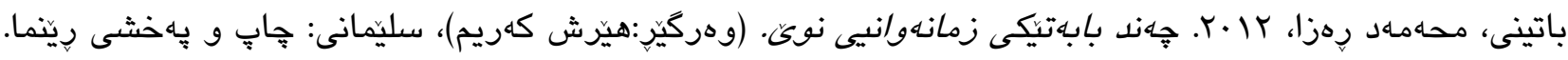

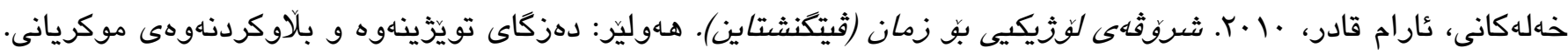

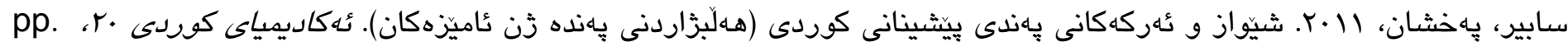
. YO. - IAr

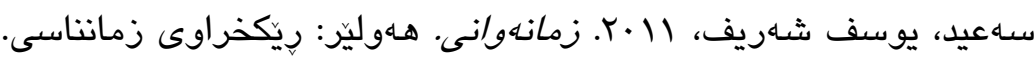

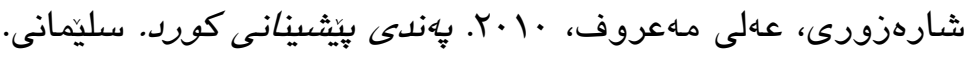

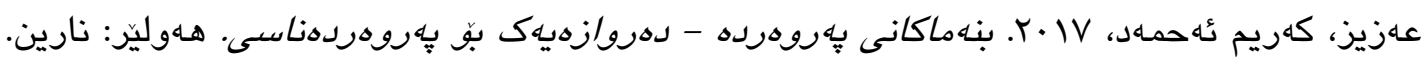
فرحان، محمد جِوب، 1919. دراسات فى فلسفة التربية. مكان غير معروف:جامعة الموصل.

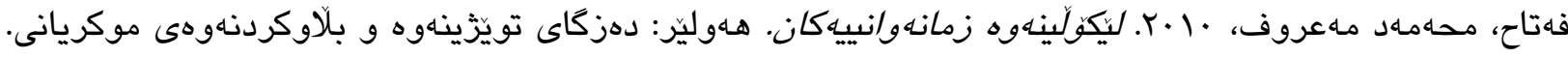

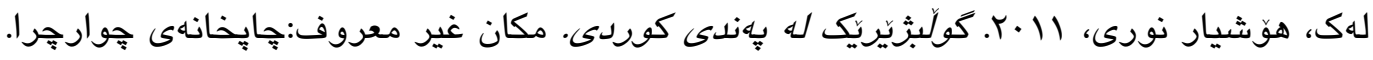
مهذى، عباس، 19AV. الذكاء و التفوق في النفس و المجتمع. ط ا المحرر بغداد: دار الثورة للصحسفة و النثر.

CRYSTAL ‘D. .2008 ‘A DICTIONARY OF LINGUISTICS AND PHONETICS. Sixth Edition

Hoque ‘M. E. .2016 ،Three Domains of Learning: Cognitive, Affective and Psychomotor. The Journal of EFL Education and Research (JEFLER)، المجلد 2 (2) ،pp. 45 - 52. 